UNIVERSIDADE DE SÃO PAULO

FACULDADE DE ECONOMIA, ADMINISTRAÇÃO E CONTABILIDADE DEPARTAMENTO DE ADMINISTRAÇÃO PROGRAMA DE PÓS-GRADUAÇÃO EM ADMINISTRAÇÃO

\author{
COMUNICAÇÃO NOS PROCESSOS DE \\ GESTÃO DE RISCO CORPORATIVO NA BM\&FBOVESPA
}

Flávio de Moraes

Orientador: Prof. Dr. Cláudio Antonio Pinheiro Machado Filho

SÃO PAULO

2012 
Reitor da Universidade de São Paulo

Professor Doutor João Grandino Rodas

Pró-Reitoria de Pós-Graduação

Professor Doutor Vahan Agopyan

Diretor da Faculdade de Economia, Administração e Contabilidade Professor Doutor Reinaldo Guerreiro

Chefe do Departamento de Administração

Professor Doutor Adalberto Américo Fischmann

Coordenador do Programa de Pós-Graduação em Administração

Professor Doutor Lindolfo Galvão de Albuquerque

Vice-Coordenador do Programa de Pós-Graduação em Administração

Professor Doutor Martinho Isnard Ribeiro de Almeida 


\section{FLÁVIO DE MORAES}

\section{COMUNICAÇÃO NOS PROCESSOS DE GESTÃO DE RISCO CORPORATIVO NA BM\&FBOVESPA}

Dissertação apresentada ao Departamento de Administração da Faculdade de Economia, Administração e Contabilidade da Universidade de São Paulo como requisito para obtenção do título de Mestre em Administração.

Orientador: Prof. Dr. Cláudio Antonio Pinheiro Machado Filho

\section{Versão Corrigida \\ SÃO PAULO}


Autorizo a reprodução e divulgação total ou parcial deste trabalho, por qualquer meio convencional ou eletrônico, para fins de estudo e pesquisa, desde que citada a fonte.

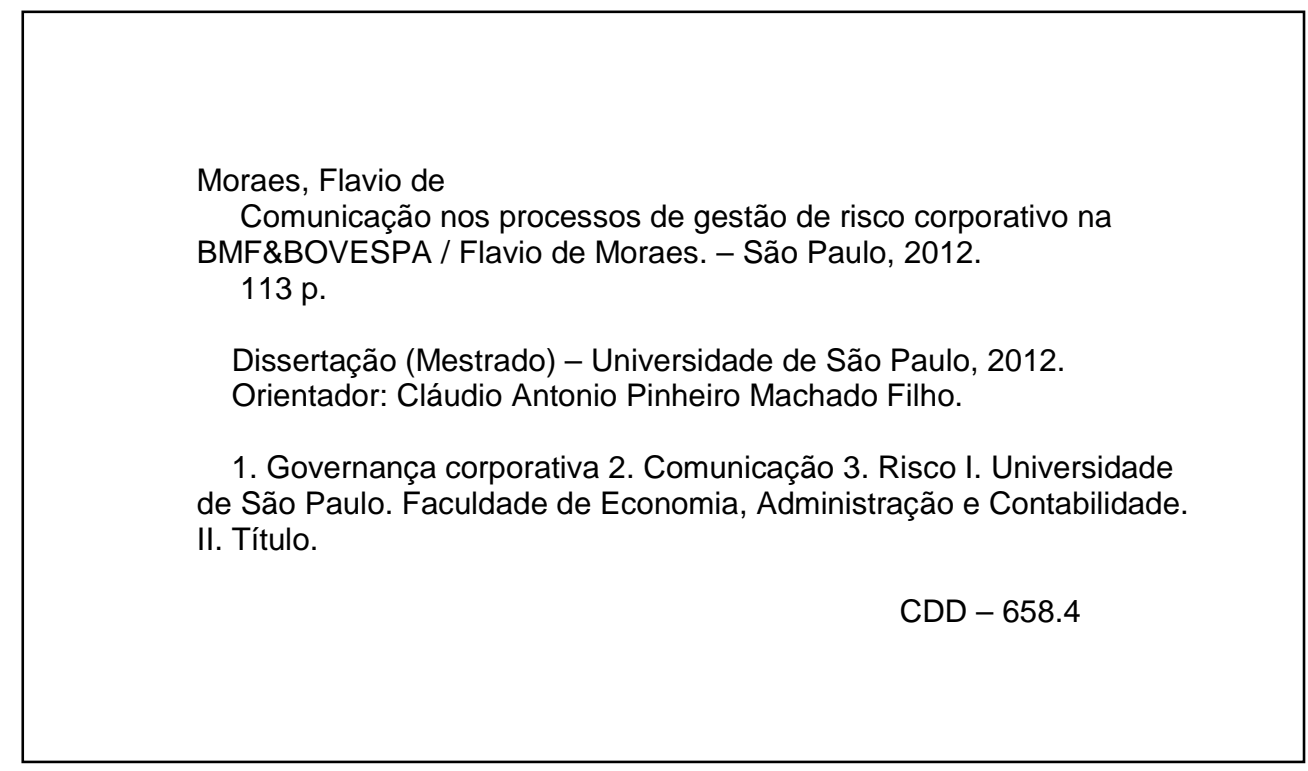


Dedico este trabalho à minha mãe, Selma Sic de Moraes. 
Agradeço Dr. Fernando Lopes Alberto e Osvaldo Oreb, pelo incentivo quando decidi iniciar o processo seletivo deste curso de pós-graduação.

Ao meu orientador, prof. Cláudio Antonio Pinheiro Machado Filho, por me aceitar como seu orientando, por me acompanhar e incentivar durante todo o curso.

Aos professores e colegas da pós-graduação, pela contribuição ao longo da construção deste trabalho.

Ao Mateus Bertti, Guilherme Macedo Lamacie e Daniel Granja, pelo tempo disponibilizado, apoio e colaboração, o que viabilizou a execução desta pesquisa.

A todos os entrevistados, pela disposição em colaborar, cedendo parcela preciosa de seu tempo e pelas informações necessárias para o desenvolvimento deste trabalho. 


\section{RESUMO}

Este trabalho aborda como é estruturada a comunicação nos processos de gestão de risco corporativo para identificar como é realizado o alinhamento das informações e percepções sobre riscos entre a gestão, conselho de administração e demais públicos interessados. Foi realizada revisão da literatura sobre Governança Corporativa, Gestão de Riscos, Gestão de Riscos Corporativos e Comunicação sobre riscos. Devido à escassez de estudos relacionados ao tema esta pesquisa possui caráter exploratório e foi utilizado o método de estudo de caso. Devido às limitações do método utilizado, as principais contribuições da pesquisa são evidências que apontam para o papel da gestão de risco corporativo como complementar à gestão de risco em silos, para a parceria entre especialistas e não especialistas em gestão de risco como fator que influencia na qualidade dos processos e da comunicação sobre riscos, bem como possíveis fatores que influenciam na formação e manutenção desta relação de parceria, além de evidências da presença de pessoas com experiência em gestão de riscos e nas atividades da empresa como possível fator que afetar a relação entre especialistas e não especialistas em gestão de riscos e a qualidade dos processos de gestão de risco.

Palavras-chave: Governança Corporativa. Gestão de Riscos Corporativos. Comunicação sobre Riscos. 


\begin{abstract}
This paper discusses how communication in enterprise risk management is structured to identify how managers, board member and other stakeholders align information and perceptions about risks. The literature review covers Corporate Governance, Risk Management, Enterprise Risk Management and Communication about risks. Due to the limitations of the method used in this research the main contributions are evidences pointing to the role of corporate risk management as complementary to the risk management silo approach, the partnership between specialists and non specialists in risk management as a factor that influences quality of processes and communication about risks and factors that might influence the formation and maintenance of this partnership relationship as well evidences of the presence of people with experience in risk management and the company's activities as a possible factor affecting the relationship between experts and nonexperts in risk management and the quality of risk management processes.
\end{abstract}

Keywords: Corporate Governance. Enterprise Risk Management. Risk Communication. 


\section{SUMÁRIO}

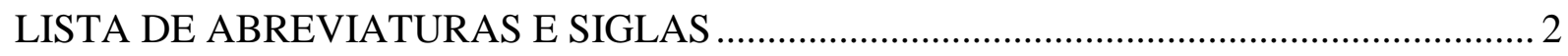

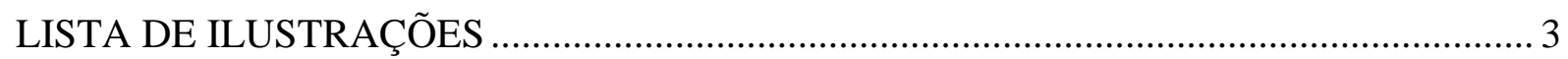

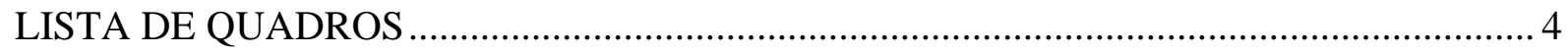

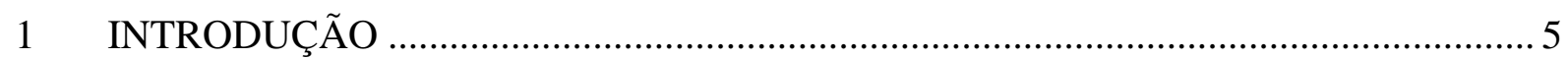

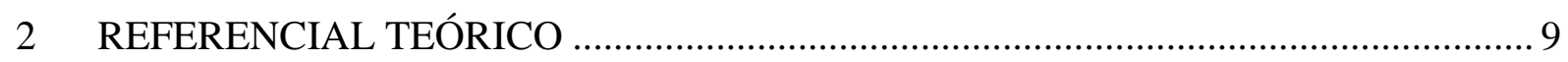

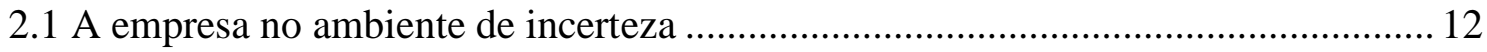

2.2 Conceito de governança corporativa e controle de ações oportunistas...................... 14

2.2.1 Monitores dos gestores ............................................................................. 20

2.2.2 Comitê de Auditoria ........................................................................................ 21

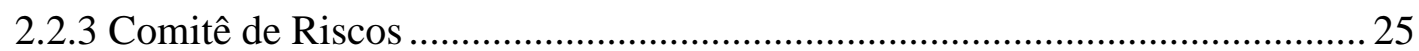

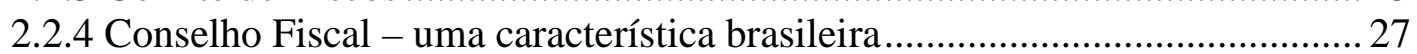

2.2.5 Comitê de Remuneração ............................................................................ 28

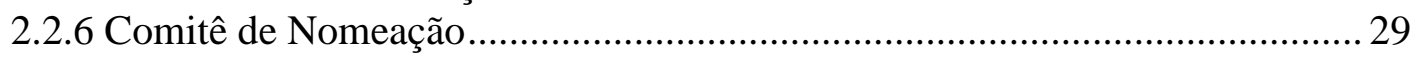

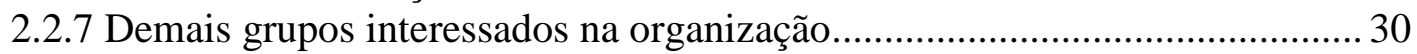

2.2.8 Maximização do valor da empresa como meta dos gestores.......................... 31

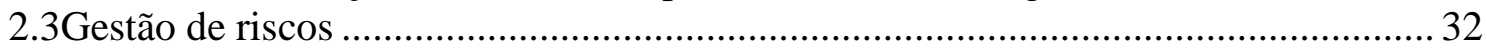

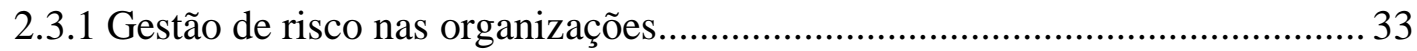

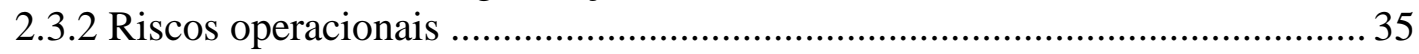

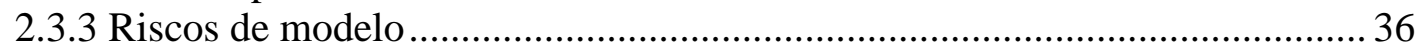

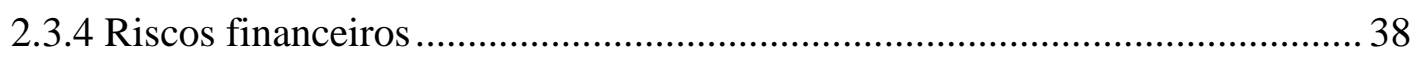

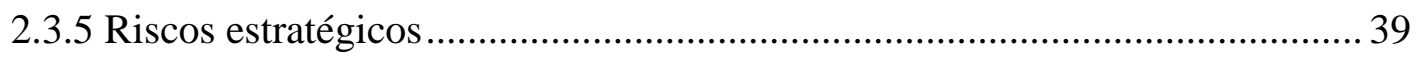

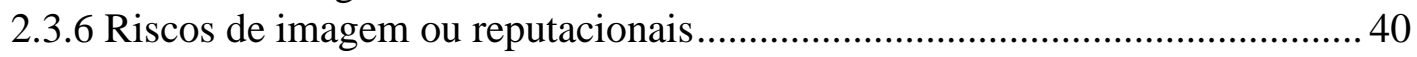

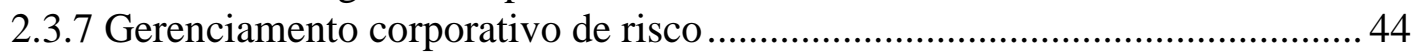

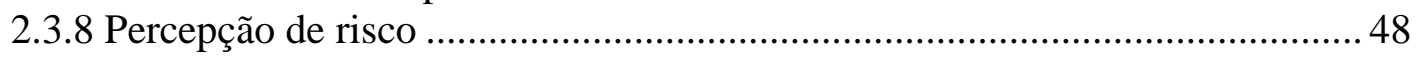

2.3.9 Comunicação sobre risco ................................................................... 51

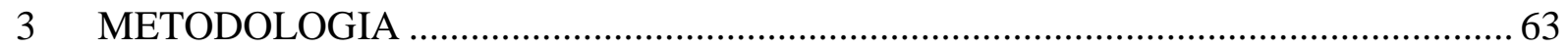

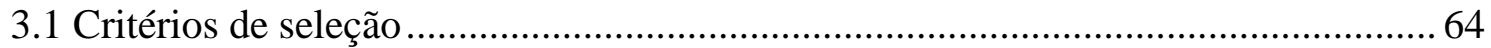

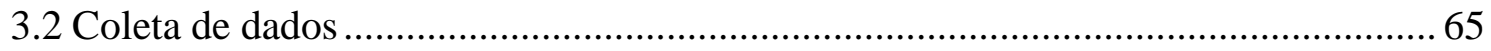

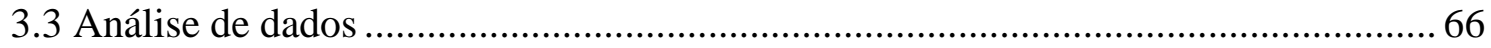

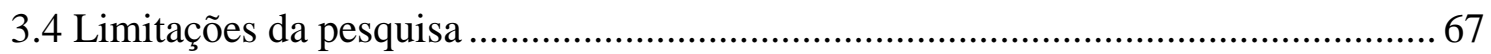

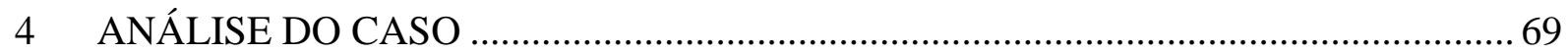

4.1 Descrição da empresa utilizada no caso: BM\&FBOVESPA.................................... 69

4.1.1 Principais estruturas de governança e de gestão envolvidas no processo de gestão de risco corporativo ............................................................................ 72

4.1.2 Comunicação sobre riscos entre as estruturas de gestão e de governança

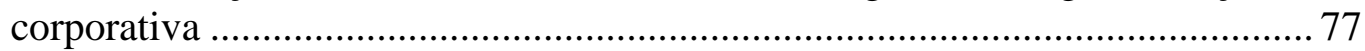

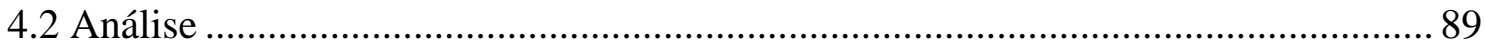

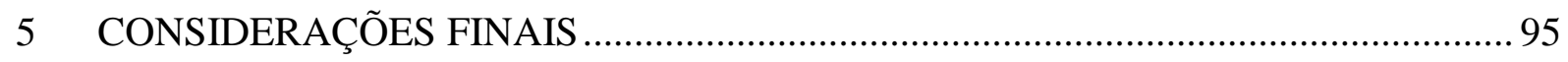

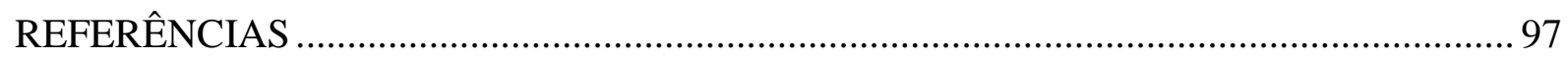

APÊNDICE 1 - QUESTÕES UTILIZADAS PARA GUIAR AS ENTREVISTAS............. 105 


\section{LISTA DE ABREVIATURAS E SIGLAS}

\begin{tabular}{|c|c|}
\hline ADR & American Depositary Receipts \\
\hline BACEN & Banco Central do Brasil \\
\hline $\mathrm{BC}$ & Banco Central do Brasil \\
\hline BIS & Bank for International Settlements \\
\hline $\mathrm{BM} \& \mathrm{~F}$ & Bolsa de Mercadorias e Futuros \\
\hline BOVESBA & Bolsa da Bahia \\
\hline BOVESPA & Bolsa de Valores de São Paulo \\
\hline BSM & BM\&FBOVESPA Supervisão de Mercado \\
\hline CAS & Casualty Actuarial Society \\
\hline CEO & Chief Executive Officer \\
\hline CETIP & Balcão Organizado de Ativos e Derivativos \\
\hline CME & Chicago Mercantile Exchange \\
\hline COSO & Committee of Sponsoring Organizations of the Treadway Commission \\
\hline CPSS & Committee on Payment and Settlement Systems \\
\hline CRO & Chief Risk Officer \\
\hline CVM & Comissão de Valores Mobiliários \\
\hline DARC & Diretoria de Auditoria e Riscos Corporativos \\
\hline ERM & Enterprise Risk Management \\
\hline IBGC & Instituto Brasileiro de Governança Corporativa \\
\hline IOSCO & International Organization of Securities Commissions \\
\hline ISO & International Organization for Standardization \\
\hline ISSA & International Securities Services Association \\
\hline NYSE & New York Stock Exchange \\
\hline PRMIA & Professional Risk Manager's International Association \\
\hline RI & Relacionamento com Investidores \\
\hline SEC & Securities and Exchange Commission \\
\hline SFA & Securities and Futures Authority \\
\hline SOX & Sarbanes-Oxley act \\
\hline
\end{tabular}




\section{LISTA DE ILUSTRAÇÕES}

Ilustração 1 - Escopo da governança corporativa

Ilustração 2 - Representação do modelo utilizado por Lasswell (2007) para entender o ato da comunicação

Ilustração 3 - Representação do modelo utilizado por Lasswell (2007) a comunicação como um todo 57

Ilustração 4 - Representação do modelo apresentado em Plough e Krimsky (1987)................58

Ilustração 5 - Estrutura permanente de governança da BM\&FBOVESPA............................... 71

Ilustração 6 - Estrutura da Diretoria Executiva da BM\&FBOVESPA ................................... 71

Ilustração 7 - Organograma com as principais estruturas de gestão e de governança

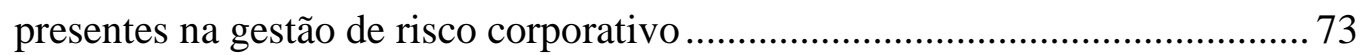

Ilustração 8 - Representação das principais estruturas envolvidas na gestão de risco e o fluxo de informação entre elas 77

Ilustração 9 - Diagrama de comunicação entre as diversas áreas 79 


\section{LISTA DE QUADROS}

Quadro 1 - Comparação entre os modelos de comunicação de Plough e Krimsky (1987) e

Lasswell (2007).

Quadro 2 - Comunicação dos níveis de apetite e tolerância a risco pelo Conselho de Administração 80

Quadro 3 - Acompanhamento periódico dos níveis de risco ................................................. 81

Quadro 4 - Solicitação de análise ad hoc pelo Conselho de Administração ............................. 81

Quadro 5 - Apresentação de resultados das análises ad hoc ................................................... 81

Quadro 6 - Resumo da comunicação de engajamento entre a DARC e áreas de negócio ........83

Quadro 7 - Comunicação entre a área de negócio e a DARC ................................................ 84

Quadro 8 - Comunicação periódica entre a área de negócio e a DARC .................................. 85

Quadro 9 - Comunicação sobre os riscos agregados entre a DARC e área de negócio ........... 85

Quadro 10 - Comunicação entre a DARC e área de negócio para disseminação de melhores práticas de gestão de riscos............................................................... 86

Quadro 11 - Comunicação dos níveis de risco pelo Presidente Executivo ............................... 86

Quadro 12 - Apresentação de resultados de análises para a Diretoria Executiva ..................... 87

Quadro 13 - Comunicação da organização com investidores e analistas ................................. 88

Quadro 14 - Comunicação entre a empresa e órgãos reguladores ......................................... 89 


\section{INTRODUÇÃO}

Para que em um país ocorra o aumento do produto per capita através do crescimento da produção de bens e serviços na economia, a sociedade precisa empregar capital e trabalho. Durante esse emprego, surge a decisão de alocação da poupança e de investimento pelos diversos agentes poupadores e investidores.

Segundo Dougall (1970), em sociedades primitivas, poupadores e usuários de capital são geralmente os mesmos ou estão próximos e, assim, como afirma Castro (1979), eles ajustam os volumes desejados de poupança e investimento. Entretanto, na sociedade capitalista moderna existem diversos poupadores e investidores com diferentes motivações. Como consequência, suas decisões ou necessidades podem não coincidir, surgindo a necessidade da intermediação financeira.

A formação de capital entendida como o crescimento de estoques de bens de capital, seria impossível sem dinheiro e um mercado para transacioná-lo (DOUGALL, 1970). O autor reconhece a necessidade de instrumentos que representem o dinheiro e sua demanda para possibilitar a transferência de recursos entre os agentes que poupam e os agentes que demandam capital para investimentos.

Castro (1979) afirma que o mercado financeiro possui os mecanismos de intermediação financeira que interligam os poupadores e os investidores. Os mercados financeiros são divididos em mercado monetário, responsável pelas transações de recursos de curto prazo, e mercado de capitais, formado por instituições e mecanismos que proveem recursos de longo prazo. Entretanto, o mercado monetário e o mercado de capitais não são independentes. Movimentos ou choques em um desses mercados causam consequências no outro que podem ser refletidos na economia de um país.

As instituições intermediárias do mercado de capitais atuam na conversão de ativos líquidos em investimentos fixos e na transformação dos prazos das operações, conciliando o desejo do poupador e do investidor, além de propiciar a liquidez dos títulos já existentes. Essas instituições atuam também na transformação dos montantes de capital, acumulando as poupanças de pequenos poupadores para formar grandes volumes de recursos e disponibilizá- 
los aos investidores, permitindo a diluição de riscos, agilidade no processo de transferência de recursos e obtenção de um grau aceitável de divulgação de informações.

Devido a essa atuação, o mercado de capitais tem papel fundamental no desenvolvimento da economia, contribuindo para a expansão do volume de poupança e permitindo que haja maior eficiência na transformação dos fundos mobilizados em capital real.

Entretanto, uma falha em algum dos intermediários que compõem a estrutura desse mercado pode causar prejuízos consideráveis para a economia e para o desenvolvimento de um país. Portanto, essas instituições passam a ser fonte potencial de riscos sistêmicos para essa economia. Devido a esta característica, as instituições do mercado de capitais são submetidas às regulações governamentais e também à autorregulamentação do mercado financeiro. Essas características contribuem para que o setor financeiro esteja entre os setores mais desenvolvidos em gestão de riscos.

No entanto, a gestão de risco dentro das organizações é tradicionalmente executada em silos. Nesta abordagem, cada departamento utiliza modelos de gestão de riscos especializados. Alterações no ambiente das empresas, como a globalização, novos competidores e novas demandas de stakeholders têm mostrado que essa abordagem possui lacunas por não contemplar os riscos estratégicos nem considerar a correlação entre os riscos que a organização está exposta. Na tentativa de preencher essas lacunas surgiu o conceito de gerenciamento integrado de risco, também conhecido como gestão corporativa de risco. Essa abordagem, entendida por alguns autores como uma evolução da gestão de risco em silos, traz uma abordagem holística, ou seja, os riscos devem ser vistos de forma integrada para fornecer aos gestores uma visão completa de todos, ou ao menos, dos principais riscos que a empresa está exposta, contribuindo para uma alocação mais eficiente dos recursos da organização.

Porém, mesmo a definição de risco é um conceito que ainda desperta discussão. No meio acadêmico, há a disputa entre o lado "hard", composto de métodos analíticos baseados em probabilidades de resultados e magnitude de seus impactos, e o lado "soft" que apresenta visões contextualizadas da realização de eventos, preocupando-se também com outras dimensões, como a população envolvida e a duração do efeito do risco. Esta disputa é ilustrada em Horlick-Jones (1998) pela reação negativa de membros da Britain's Royal Society aos capítulos 5 e 6 do trabalho Risk: Analysis, Perception and Management publicado pela mesma instituição. Estes dois capítulos abordam os temas da percepção de risco e da 
gestão de riscos através da perspectiva de cientistas sociais, utilizando uma abordagem qualitativa, enquanto os quatro primeiros capítulos, que não sofreram as mesmas críticas, possuem abordagem quantitativa.

Uma lacuna semelhante ocorre entre especialistas em risco e o público geral, também chamado de leigo (em gestão de riscos). Essa lacuna ocorre devido à diferença de visões e assimetria informacional, causando diferenças na percepção sobre os riscos, podendo resultar em dúvidas e desconfianças entre os dois lados, dificultando a gestão eficaz e eficiente de riscos.

Para reduzir a assimetria de informação e promover o alinhamento da percepção entre os envolvidos, é necessária uma comunicação eficaz sobre os riscos a que a organização está exposta. Essa comunicação deve permitir o fluxo de informação, de modo que especialistas entendam as preocupações dos stakeholders, considerando-as em suas decisões, e que estes últimos entendam as decisões tomadas pelo primeiro grupo. É esperada que uma comunicação de risco eficaz reduza a assimetria de informação e promova o alinhamento das percepções, reduzindo conflitos e estabelecendo uma visão comum que considere os pontos de vista de todos stakeholders.

Em trabalhos acadêmicos e não acadêmicos, é descrita a necessidade da comunicação das decisões sobre risco entre as partes interessadas, evidenciando a importância do tema. Porém, não foram localizadas referências que descrevam como as organizações realizam ou deveriam realizar a comunicação sobre riscos com seus stakeholders, considerando o alinhamento de suas percepções. Identificou-se, portanto, uma lacuna no conhecimento sobre gestão de riscos relacionada à redução de assimetria de informação e alinhamento da percepção sobre os riscos que a empresa está exposta.

Explorando essa lacuna identificada, este estudo procura responder: Como é o processo de comunicação sobre riscos entre estruturas de gestão, governança corporativa e stakeholders para alinhamento de informações e percepções sobre os riscos em organizações intermediadoras no mercado de capitais?

Espera-se que o estudo de uma instituição com papel central no mercado de capitais forneça conclusões que possam contribuir para o conhecimento de gestão de riscos e de redução de assimetria de informações entre stakeholders, pois é esperado que a gestão de risco desta organização possua grau de desenvolvimento compatível com o restante do setor financeiro. 
Com base no problema de pesquisa, propõem-se os seguintes objetivos específicos: a) Identificar e analisar a relação entre as estruturas de governança e de gestão de empresas intermediárias no mercado de capitais e seus papéis nos processos de gestão de riscos corporativos; b) Analisar como ocorre a comunicação sobre riscos e a transmissão da percepção sobre os riscos entre as áreas de Gestão de Risco, Diretoria e Conselho de Administração; e c) Analisar como ocorre a comunicação sobre riscos e a transmissão da percepção sobre os riscos entre empresas intermediadoras e os órgãos regulatórios, mercado financeiro e governo.

A relevância desta pesquisa deve-se à preocupação crescente pelas empresas e por seus stakeholders sobre como os riscos aos quais essas organizações estão expostas são geridos. As conclusões do estudo da comunicação na gestão de risco da organização selecionada podem contribuir com o conhecimento sobre gestão de riscos e conhecimento sobre medidas para a redução de assimetria de informação ou alinhamento de percepções entre stakeholders. Outros pontos que contribuem para a relevância da pesquisa são a importância do mercado de capitais e seus efeitos na economia do Brasil e de outros países.

A factibilidade desta pesquisa ocorre devido ao acesso às fontes necessárias, tanto internas da organização estudada como externas, pois o autor é funcionário da organização, o que também traz algumas limitações à pesquisa, que são discutidas no capítulo referente à metodologia.

Esta pesquisa também contribui com uma descrição e análise da comunicação no processo de gestão de risco corporativo, para o conhecimento sobre gestão de riscos nas organizações. Para a sociedade, os resultados desse estudo levantam elementos que podem auxiliar outras organizações a aprimorarem os processos de gestão de risco. Para isso, este estudo está organizado em quatro capítulos. O primeiro capítulo destina-se à introdução, contextualiza e estabelece a situação do problema de pesquisa e seus objetivos. O segundo capítulo é composto da revisão teórica, abrangendo tópicos relacionados à Governança Corporativa, Gestão de Riscos Corporativos, Comunicação e Comunicação em Gestão de Riscos. No terceiro capítulo é apresentada e descrita a metodologia utilizada nesta pesquisa e suas limitações. No quarto capítulo é apresentado o caso e a sua análise. As considerações finais sobre o caso e propostas para novos estudos são apresentadas no quinto capítulo. 


\section{REFERENCIAL TEÓRICO}

Segundo Knight (1957) e Coase (1937), no ambiente de concorrência perfeita descrito pelos modelos neoclássicos não existem custos de transação e os agentes econômicos possuem racionalidade plena. Estes autores afirmam que neste cenário, tanto as quantidades transacionadas como os recursos seriam alocados da forma ótima.

Knight (1957) também acrescenta que neste contexto não é possível obter lucro, pois o preço estabelecido pelo mercado seria equivalente ao custo de produção. Barzel e Suen (1997) complementam o raciocínio afirmando que neste cenário as empresas utilizariam a combinação de insumos e processos ótimos. Como consequência, empresas que produzissem os mesmos bens seriam idênticas em processos e insumos utilizados e escala.

Devido à não ocorrência destas características dentre outras, Knight (1957), Coase (1937), Simon $(1978,1986)$ e outros autores refutam as características de concorrência perfeita como prevalecente no mundo real. Para estes autores, a realidade econômica é composta de atores com racionalidade limitada, resultando em incertezas, custos de transação e oportunidades de lucro para as empresas.

Simon (1978) critica a economia neoclássica, pois para o autor este ramo da economia tem estudado a alocação racional de recursos escassos, quando o foco deveria ser o processo de alocação de recursos escassos. Estudos nesta área têm focado no resultado da escolha racional ao invés dos processos utilizados nas escolhas reais, levando a análises sobre preços e quantidades ideais ao invés de entender os processos de escolhas utilizados pelos agentes econômicos.

Simon $(1978,1986)$ compara o conceito de racionalidade da economia neoclássica com os utilizados em outras ciências sociais. $\mathrm{Na}$ economia neoclássica, o indivíduo possui racionalidade considerada plena e maximizadora de utilidade, resultando em ações sempre coerentes em relação ao ambiente presente e futuro. Entretanto, outras ciências sociais consideram que a mente humana e a capacidade de atenção do indivíduo são recursos escassos. Como decorrência da escassez destes recursos, os indivíduos possuem capacidade limitada de processamento cognitivo e de concentração, resultando em racionalidade limitada. 
Devido aos indivíduos possuírem racionalidade limitada, o ambiente econômico é composto de incertezas e custos de transação. Portanto a comunicação é imperfeita surgindo assimetria de informação entre os agentes econômicos. Como consequência destas condições, um bem pode ser transacionado por preço superior ao seu custo de produção. Knight (1957) conclui que a incerteza presente no mundo real é condição essencial para que os agentes econômicos obtenham lucro.

Tanto Knight (1957) como Barzel e Suen (1997) afirmam que as incertezas são geradas pela variabilidade presente no ambiente, pois os indivíduos não possuem capacidade cognitiva para avaliar todos os resultados decorrentes destas variabilidades. Estes autores não desprezam as variabilidades causadas por forças da natureza, mas consideram que a principal origem das incertezas são as variabilidades originadas pelas ações dos atores econômicos.

Knight (1957) diferencia risco de incerteza ao definir risco como eventos que possuem probabilidades de ocorrências conhecidas ou estimadas, e como incerteza os eventos em que não é possível atribuir ou estimar probabilidades. Considerando que os agentes econômicos possuem racionalidade limitada, estes não são capazes de estimar as probabilidades e consequências de um evento em tempo hábil. Portanto, mesmo eventos com probabilidades conhecidas possuem algum grau de incerteza.

Neste ambiente com incerteza, comunicação imperfeita e racionalidade limitada os atores econômicos agem baseados em condições do passado ou em inferências incertas sobre o futuro. Para Simon (1978), caso os agentes econômicos possuíssem racionalidade plena suas percepções seriam iguais à realidade, contudo, como possuem racionalidade limitada há diferença entre a percepção do indivíduo e a realidade. North (1994) complementa que os agentes econômicos atuam baseados em modelos subjetivos com diversas falhas, mas que estes modelos estão em evolução constante, sendo aprimorados pelas percepções do indivíduo que os possuem.

Entretanto, tanto Williamson (2000) como North (1991) afirmam que as incertezas do ambiente podem ser influenciadas pelas instituições. Esta influência pode ocorrer através de mecanismos informais, como a cultura e os costumes, ou por mecanismos formais, como a política, o sistema judiciário e os mecanismos de governança. As incertezas do ambiente podem ser reduzidas pelas instituições através da formação e enforcement de regras que 
restringem as ações dos atores econômicos e auxiliam na resolução de divergências nos modelos subjetivos dos indivíduos.

No sistema financeiro brasileiro existe a presença das instituições formais tradicionais, como o governo e o sistema legal, além de instituições específicas deste mercado, como a Comissão de Valores Mobiliários (CVM) e as regulações do Banco Central do Brasil (BC). Dentre estas últimas, há instituições intermediárias ${ }^{1}$ que podem contribuir para a formação e enforcement da autorregulamentação ${ }^{2}$, além de influenciarem na disseminação de informações e liquidez dos ativos negociados. Desta forma, conforme descrito em Williamson (2000) e North (1991) estas instituições podem colaborar para a redução de incerteza, tanto na restrição dos agentes envolvidos como na redução da assimetria de informação entre eles.

Portanto, a possibilidade de lucro está relacionada à incerteza do ambiente e a assimetria de informação entre os indivíduos, originadas na racionalidade limitada e nos custos de transação. Nesse ambiente, a percepção do indivíduo pode ser diferente da realidade, resultando em alocação menos eficiente de recursos para a transformação de incertezas em riscos e gerenciamento destes.

Desta forma, uma organização pode estar exposta ou alocar recursos insuficientes para prevenir eventos significativos ou alocar recursos em demasia em eventos pouco relevantes para a sua sobrevivência. No contexto do mercado de capitais brasileiro, as instituições tradicionais, como órgãos do governo e o sistema legal, e as especializadas formadas principalmente pela CVM, regulações do BC e autorregulação da BM\&FBOVESPA, colaboram para a redução de incertezas e assimetria informacional, tornando a gestão destas incertezas e assimetrias crucial para funcionamento deste mercado e para a economia do país.

\footnotetext{
${ }^{1}$ Instituições intermediárias do mercado financeiro são instituições que captam depósitos e fornecem crédito tanto para pessoas físicas como jurídicas. As principais instituições estão constituídas sob a forma de bancos múltiplos, mas existem também os bancos comerciais, bancos de investimento, caixas econômicas, banco cooperativas, cooperativas de crédito, empresas corretoras e sociedades de crédito (BACEN, 2011).

${ }^{2}$ Autorregulação consiste na elaboração e estabelecimento pela própria comunidade das normas que disciplinam suas atividades. A CVM adota a autorregulação para determinadas atividades no mercado de valores mobiliários para aumentar sua eficiência e atividade regulatória, evitando a centralização excessiva do poder. Esta decisão está fundamentada também na redução de custos e por considerar que uma entidade autorreguladora possui mais conhecimento e sensibilidade para avaliar as atividades deste mercado.
} 


\subsection{A empresa no ambiente de incerteza}

Jensen e Meckling (1976) destacam a visão da empresa como um nexo de contratos. Segundo estes autores, a organização é uma ficção legal que realiza processos complexos na qual existem objetivos conflitantes entre os indivíduos. Estes conflitos são equilibrados pela organização através de relações contratuais. Barzel e Suen (1997) expandem a visão de Jensen e Meckling (1976) definindo a organização como um nexo de contratos garantidos pelo capital próprio da organização. Fama e Jensen (1983b) compartilham da visão de Barzel e Suen (1997) ao afirmarem que a empresa reduz as incertezas para seus stakeholders.

Neste contexto, a empresa tem o papel de absorver parte das incertezas do ambiente através de relações contratuais, utilizando capital próprio para garantir o cumprimento destes contratos. Portanto, na visão apresentada por Barzel e Suen (1997) o escopo da empresa possui relação direta com o conjunto de contratos que são garantidos pelo capital da organização. Os autores destacam que o capital garantidor das transações não é o capital físico em si, mas a propriedade deste capital físico e o capital reputacional.

Como consequência, empresas cujos proprietários possuem pouco capital enfrentam restrições nas garantias que conseguem oferecer, limitando o tamanho de suas organizações. Entretanto, os indivíduos podem se associar para aumentar o capital de garantia de uma organização. Barzel e Suen (1997) afirmam que este capital garantidor possui ganhos de escala, logo, um aumento de capital da empresa resulta em aumento mais que proporcional no acréscimo de garantias que esta empresa poderá oferecer.

Da associação de indivíduos para aumentar o capital de uma empresa surge a necessidade de medidas para evitar ou mitigar ações oportunistas entre os associados. Os incentivos para ações oportunistas surgem neste contexto devido à assimetria de informações e porque o indivíduo busca seu próprio interesse, mas possui somente uma fração do capital da empresa. Desta maneira, um agente oportunista receberá a totalidade dos benefícios de suas ações, porém a responsabilidade, o custo e os riscos destas ações serão compartilhados entre todos os associados, caracterizando o conceito de risco moral (moral hazard). 
Ações oportunistas podem comprometer o futuro da organização devido ao sacrifício de capital que esta pode vir a incorrer, caso uma garantia seja acionada como decorrência destas ações. O abuso entre os associados é possível devido à impossibilidade da elaboração de um contrato prevendo todas as contingências e também devido à assimetria de informação que pode existir entre os associados durante o cumprimento do contrato, devido à dificuldade ou impossibilidade de mensuração das ações de um associado pelos demais.

Uma relação com estas características é classificada por Jensen e Meckling (1976) como uma relação de agência. Estes autores definem a relação de agência como um contrato no qual uma ou mais pessoas (principais) atribuem a outras pessoas (agentes) poderes para tomarem decisões para realização de serviços em seus nomes. Fama (1980) considera que este tipo de relação pode ser um arranjo economicamente eficiente, porém Fama e Jensen (1983b) afirmam que o controle desta relação é essencial para a sobrevivência da organização.

Uma dificuldade destacada por Alchian e Demsetz (1972) neste contexto é a mensuração do esforço dos gestores para contribuir com o resultado da empresa. Essa dificuldade é acentuada, segundo Barzel e Suen (1997), quando é pequena a parcela do capital da organização que cada indivíduo possui, reduzindo os incentivos para adquirir informações sobre a empresa e para monitorar as ações dos gestores, resultando no aumento da assimetria de informação entre proprietários e gestores.

A solução inicial proposta em Alchian e Demsetz (1972) é definir um indivíduo como monitor da organização e com o direito residual sobre os resultados do grupo. Entretanto, o direito residual sobre os resultados da organização já está alocado e disperso entre os diversos proprietários. No caso, os autores apontam como uma possível solução a delegação do poder de monitorar e alterar os gestores para um grupo menor, restando aos investidores reverem periodicamente a composição deste novo grupo.

A partir da visão de Barzel e Suen (1997), pode ser entendido o papel dos intermediários do mercado de capitais. Estas instituições atuam como garantidoras das operações realizadas neste mercado. Pois quando um agente envolvido numa negociação não cumpre sua parte no contrato, o intermediário envolvido deverá utilizar capital próprio para honrar esta operação frente à outra parte. 
Devido ao alto volume de recursos envolvidos nas operações no mercado de capitais, o capital de seus principais intermediários é composto pelo investimento de diversos indivíduos, surgindo incentivos para ações oportunistas e necessidade de monitoração entre estes.

O papel garantidor destes intermediários também cria incentivos para ações oportunistas pelos atores envolvidos nas negociações. Para coibir este tipo de ação por esse público, as organizações intermediadoras podem solicitar aos atores envolvidos nas operações o depósito de capital adicional, além do utilizado nas operações, para auxiliar na composição do capital garantidor do mercado.

A atividade garantidora destes intermediários é, portanto, crucial para a estabilidade deste mercado e crescimento da economia. Para que as organizações consigam cumprir esta atividade, são necessárias medidas para controlar ações oportunistas e para gerir os riscos a que estão expostas de modo a garantirem a sua sobrevivência no longo prazo.

Há organizações intermediadoras do mercado de capitais, cujas atividades e contratos visam absorver parte das incertezas do ambiente gerando lucros para seus acionistas. Porém, diferente de outros setores, como o industrial ou de construção civil, a incerteza é parte substancial do ambiente, considerado até mesmo parte de produtos do setor financeiro, principalmente os produtos classificados como derivativos. Adiciona-se a estas características o alto volume de capital necessário para a montagem e operação deste tipo de organização, característica que auxilia que estas empresas sejam compostas de associações de muitos indivíduos, como no caso brasileiro, surgindo a necessidade de medidas para evitar ou mitigar as ações oportunistas dos dirigentes da organização. Por conseguinte, o próximo tópico deste capítulo explora a disciplina Governança Corporativa e os mecanismos e estruturas que esta dispõe para monitorar os gestores de organizações.

\subsection{Conceito de governança corporativa e controle de ações oportunistas}

Jensen e Meckling (1976) afirmam que em organizações onde todo o capital pertence a uma pessoa, esta pessoa maximizará sua função-utilidade. Fama (1980) concorda e aprofunda esta ideia ao afirmar que o empreendedor personifica a organização assumindo o controle e o risco residual da empresa. Entretanto, quando o gestor possui apenas parte ou nenhuma 
participação no capital da organização surgem incentivos para que este se aproprie de recursos dos demais acionistas, surgindo a necessidade de monitoração do gestor pelos sócios externos para evitar o moral hazard.

A separação entre propriedade e controle é entendida por Fama e Jensen (1983a) como uma especialização entre tomada de decisão e tomada de riscos. Fama (1980) considera que ambos são fatores de produção da firma e que possuem mercado que oferece alternativas para seu uso.

Segundo Fama e Jensen (1983a) a especialização na tomada de risco permite aos acionistas diluírem os riscos a que estão expostos através de um portfólio de investimentos. Como consequência, Fama (1980) explica que o tomador de risco aceita a incerteza ao investir seu capital em uma empresa, sendo que o valor do investimento, ou o preço das ações, reflete os riscos que está tomando. $\mathrm{O}$ autor complementa que a propriedade do capital não é a propriedade da empresa, logo, a propriedade da firma seria irrelevante para os acionistas.

Fama e Jensen (1983a) consideram que a especialização da gestão traz benefícios para a organização, uma vez que indivíduos com este tipo de habilidade não possuem necessariamente riqueza suficiente ou apetite a risco ${ }^{3}$ para tornarem-se sócios controladores de empresas. Porém, destacam como ponto negativo desta especialização o conflito de interesses entre os tomadores de decisão e os tomadores de riscos, resultando em custos que classificam como custos de agência. Para minimizar estes custos, entendem que a separação entre tomada de decisão e tomada de riscos deveria especificar a natureza dos direitos residuais e os papéis dos agentes no processo decisório.

Para Hill e Jones (1992), a teoria da agência possui foco na relação entre gestores e os stockholders da organização. Eisenhardt (1989a) considera que o problema de agência surge do conflito entre os objetivos dos proprietários (principais) e dos gestores (agentes), pois estes atores possuem diferentes objetivos e atitudes em relação ao risco. Desta forma, a autora entende que o objetivo da Teoria da Agência é identificar estes conflitos e descrever mecanismos de governança que limitem a expropriação dos principais pelos agentes.

\footnotetext{
${ }^{3}$ COSO (2004, p. 43) define apetite a risco como "o nível de risco que a organização pode aceitar na busca e realização de sua missão".
} 
Na Teoria da Agência a informação é vista como uma commodity, ou seja, pode ser produzida ou comprada, portanto possui custo. Jensen e Meckling (1976) concordam com esta visão ao afirmarem que as ações de incentivo e de monitoração dos principais possuem custos. Estes custos são classificados em custos de monitoração, custos de produzir as informações para os proprietários e custos devido a perdas residuais. Porém, segundo os citados autores, esses custos podem ser reduzidos com o tempo através da reputação dos gestores. Outra característica desta teoria é a importância dos incentivos para alinhar os interesses dos agentes aos dos principais.

Entretanto, Jensen e Meckling (1976) afirmam que a dispersão dos acionistas reduz os incentivos destes para monitorarem os gestores, pois os custos da monitoração nesta condição serão superiores aos ganhos individuais, abrindo espaço para abusos pela gestão. Fama (1980) contrapõe este ponto ao afirmar que as empresas são disciplinadas pela competição, que força a presença e a evolução do monitoramento do desempenho dos gestores pelos acionistas.

Os abusos da gestão têm origem na divergência de interesses entre os proprietários e os gestores, pois os proprietários esperam que os gestores concentrem seus esforços e recursos da empresa para maximizar o valor desta, enquanto os gestores podem tomar diversas ações em busca do beneficio próprio. Tirole (2006) classifica estes abusos em três categorias. Na primeira, os executivos realizam esforço insuficiente ou concentram seu tempo em atividades secundárias para empresa. Outra forma de abuso é a realização de investimentos extravagantes para satisfação própria. Por último, a gestão, que pode tomar ações de entrincheiramento para assegurar sua posição na organização. $\mathrm{O}$ autor também apresenta dois modos para obter o alinhamento entre proprietários e gestores. O primeiro é composto de incentivos que direcionem os gestores a realizarem esforços e utilizarem os recursos da empresa de acordo com os interesses dos proprietários. O segundo é através de monitoração e intervenção nas ações dos gestores, que pode culminar com a retirada do gestor da organização.

Os incentivos de alinhamento entre os interesses dos agentes com os dos principais são classificado pelo autor como formal, informal ou de motivação própria. Ele considera como incentivos formais a presença de bônus e a oferta de ações ou de opções de ações da empresa na remuneração do gestor. A possibilidade de demissão, seja pela decisão do Conselho de 
Administração, via take over hostil ${ }^{4}$ ou por proxy fights ${ }^{5}$, e a monitoração do mercado são exemplos de mecanismos informais. A motivação própria é resultado do desejo por status, da autoestima, do altruísmo e de outros sentimentos relacionados a estes.

Tirole (2006) salienta que um pacote de remuneração mal estruturado pode causar o efeito contrário, proporcionando desalinhamento entre os interesses dos acionistas e gestores. Uma característica destacada como crítica pelo autor é o critério de avaliação dos gestores para determinar o valor da remuneração variável destes, principalmente quando parte substancial desta remuneração é composta por stock options. Segundo o autor, critérios que não reflitam o desempenho da organização não incentivam os gestores a despenderem esforços para melhorar o resultado da empresa. Outra situação de atenção destacada ocorre quando a organização apresenta desempenho ruim, ameaçando a remuneração variável dos gestores. Neste contexto, o autor afirma que existem incentivos para os gestores tomarem medidas drásticas expondo a organização a riscos elevados, ameaçando a sobrevivência desta.

Jensen e Meckling (1976) e Fama e Jensen (1983b) adicionam que a competição pela gestão da empresa também é uma ferramenta que pode alinhar os interesses dos gestores com os dos proprietários, sendo que Fama e Jensen (1983b) consideram como atividade do Conselho de Administração estimular a competição interna para forçar a disciplina pelo mercado.

A monitoração dos gestores pode ser realizada por diversos agentes, dentre eles, Tirole (2006) destaca o Conselho de Administração, os acionistas majoritários, os grandes credores, bancos de investimentos e agências de rating. Para o autor, a monitoração pode ser ativa, através da intervenção na gestão, ou especulativa, que pode influir no aumento ou redução de investimentos na organização. Fama e Jensen (1983b) acrescentam que a monitoração interna pelos pares dos gestores também pode ser efetiva.

\footnotetext{
${ }^{4}$ Take over hostil é considerado por Tirole (2006) um mecanismo de monitoração pelo mercado. Neste mecanismo uma entidade ou grupo de entidades, que podem ser pessoas físicas ou jurídicas, acreditam que determinada organização é mal administrada. Portanto, este grupo faz uma oferta para obter o controle da organização e alterar sua administração, normalmente demitindo conselheiros e executivos, para alterar a forma como esta organização é gerida com objetivo de melhorar seus resultados e aumentar seu valor de mercado.

${ }^{5}$ Proxy fights ocorrem quando há um grupo de acionistas descontentes com a gestão, mas sem quantidade de votos suficientes para retirar os atuais conselheiros ou executivos. Estes acionistas se engajam em uma campanha para obter o apoio de outros acionistas para alcançar a quantidade mínima de votos para provocar uma nova eleição do Conselho de Administração ou retirar os atuais executivos da gestão da organização (TIROLE, 2006).
} 
Outro mecanismo considerado por Tirole (2006) é o ativismo dos acionistas através da monitoração ativa e intervenção na gestão. Entretanto, o autor destaca que neste mecanismo o grupo ativista necessita do controle da organização, pela propriedade da maioria dos votos ou pela formação de alianças. Outras características consideradas necessárias pelo autor são a reputação dos iniciadores do movimento, a necessidade de uma comunicação fácil entre os proprietários e a ausência do conflito de interesses entre estes. $\mathrm{O}$ autor complementa que o sucesso deste mecanismo decorre também do perfil e concentração dos investidores. Entretanto, considera que o ativismo dos acionistas pode despertar outro problema, que é o conflito de interesse entre o grupo que detém o controle e os proprietários minoritários. Outros possíveis efeitos negativos deste mecanismo são a possibilidade do grupo de controle realizar acordos com os gestores e a autoconcessão de benefícios entre os acionistas controladores.

Tirole (2006) também considera que tanto os incentivos como a monitoração podem causar efeitos negativos, pois a composição equivocada destes mecanismos pode resultar em foco no resultado de curto prazo, podendo causar manipulações contábeis ou outras ações que ameacem a perpetuidade da empresa.

A partir destas ações, os proprietários tentam assegurar o retorno sobre o investimento realizado, sendo esta a definição de Tirole (2006) para Governança Corporativa.

La Porta et al (2001) definem Governança Corporativa como o conjunto de mecanismos que visam proteger os investidores contra expropriação pelos insiders da organização. Estes autores entendem que os principais precisam de informações para exercer seus direitos, e que estas informações podem ser obtidas por meio de medidas que aumentem a transparência e o accountability da organização. Desta forma, como representado pela Ilustração 1, o escopo da governança corporativa envolve os acionistas, os mecanismos e estruturas que visam proteger os investimentos dos acionistas de ações oportunistas dos gestores e os gestores. Portanto, este escopo necessariamente possui sobreposição com o escopo da gestão. 


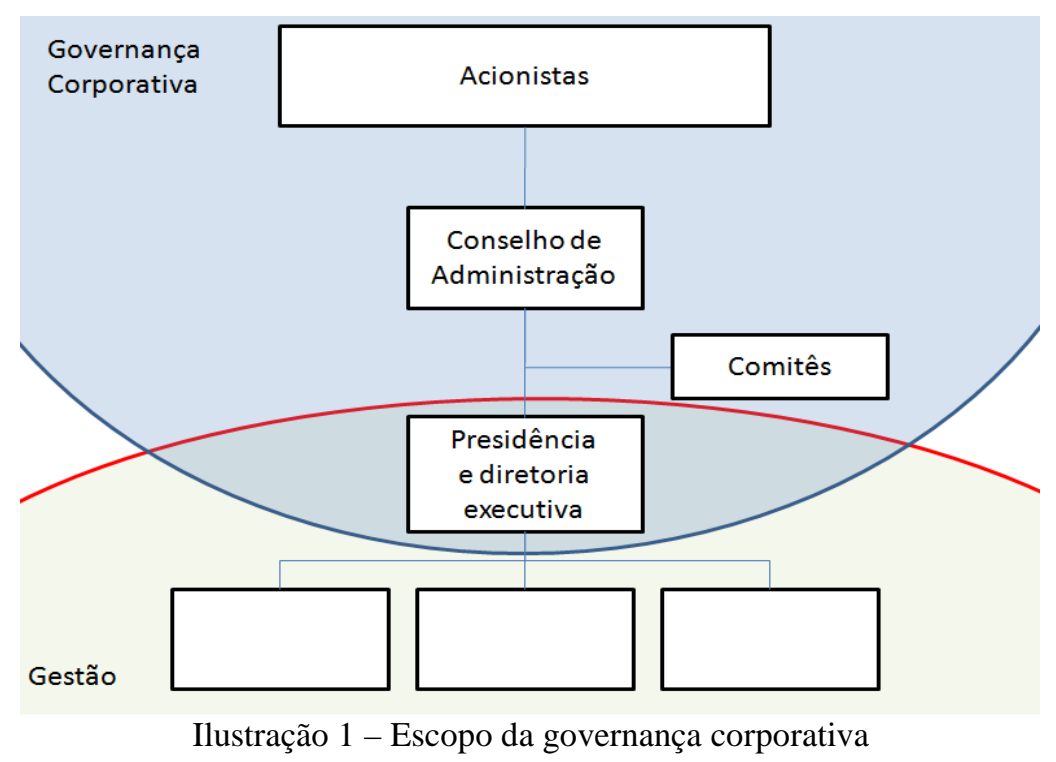

Outra forma de proteção aos acionistas destacada por Tirole (2006) são as instituições, tanto formais como informais. Contudo, destaca que as instituições variam entre os países, principalmente devido à sua cultura.

La Porta et al (2001) enfatizam a existência do sistema legal como mecanismo de proteção para os acionistas. Os autores consideram que tanto as cortes como os reguladores legais e os participantes do mercado podem aumentar o enforcement da legislação, e afirmam que há uma relação negativa entre o grau de proteção legal e o grau de concentração de capital.

Os mecanismos de Governança Corporativa são considerados imperfeitos por Tirole (2006). Como sintomas de mau funcionamento destes mecanismos, o autor destaca a falta de transparência da gestão, remuneração pouco relacionada ao desempenho da empresa, a existência de golden parachutes ${ }^{6}$ e manipulações contábeis.

De acordo com La Porta et al (2001) a concentração de capital pode originar outro problema de agência, porém na relação entre acionistas majoritários e minoritários. Neste conflito, os acionistas majoritários atuam como agentes e possuem incentivos para expropriar os minoritários, neste caso, os principais. Entretanto, afirmam que a estrutura de capital concentrado é mais frequente do que a estrutura pulverizada, como decorrência é previsto que

\footnotetext{
${ }^{6}$ Golden parachutes são acordos entre os executivos e a organização que concedem ao executivo certos benefícios em caso de término do contrato. Estes benefícios podem incluir pagamento de altos valores de indenização, ações ou opções sobre ações da empresa.
} 
seja maior a frequência de conflitos entre acionistas majoritários e minoritários do que conflitos entre gestores não controladores e acionistas.

Uma solução identificada por Fama e Jensen (1983b) para o problema de agência é a delegação do controle das decisões para um grupo menor, o Conselho de Administração. Os autores propõem que nesta solução, as atividades de execução, compostas de geração e implantação de iniciativas, sejam separadas das atividades controle, compostas de ratificação e monitoramento. Deste modo, as atividades de execução são atribuídas à gestão, enquanto as atividades monitoramento são realizadas pelo Conselho de Administração. Os autores entendem que a separação efetiva destas atividades pode ser crucial para a sobrevivência da organização.

\subsubsection{Monitores dos gestores}

O principal órgão da Governança Corporativa é o Conselho de Administração, cuja principal responsabilidade é monitorar as ações dos gestores e aprovar as decisões estratégicas da organização. Fama e Jensen (1983b) atribuem ao Conselho atividades de ratificação e monitoramento das decisões da gestão.

Fama (1980) considera que um Conselho formado somente por acionistas não é uma composição ótima, pois tomadores de risco não possuem necessariamente o conhecimento e habilidades para a tomada de decisões de qualidade. O domínio do Conselho por executivos também não é visto pelos autores como eficiente, pois esta composição pode reduzir a competição interna pela gestão, além de facilitar a expropriação dos acionistas pelos gestores.

Fama (1980) propõe que o Conselho seja formado por acionistas, executivos e conselheiros independentes, mas com predomínio de conselheiros independentes, pois considera que estes conselheiros possuem poucos incentivos para realizarem acordos com a gestão. Fama e Jensen (1983b) destacam os incentivos reputacionais como principal incentivo para que os conselheiros independentes não realizarem acordos com os gestores.

Algumas características destacadas por Tirole (2006) podem afetar o funcionamento do Conselho. Dentre elas estão a falta de independência, quando a maioria dos conselheiros 
possui algum vínculo com a empresa ou com os gestores, a atenção insuficiente por parte dos conselheiros, a falta de incentivos e a tomada de postura que evite conflitos com os gestores.

Segundo Tirole (2006), esse órgão pode se desdobrar em comitês especializados. Kose e Senbet (1998) consideram que a eficácia do Conselho de Administração pode ser afetada tanto pela sua composição como também pela sua estrutura interna; e citam o estudo de Klein (1995) que identifica que estruturas com papéis especializados podem melhorar o desempenho do Conselho.

A operação de atividades do Conselho em Comitês pode aumentar a eficácia do Conselho de Administração (MENON; WILLIAMS, 1994), pois esta separação permite que cada membro do conselho de administração possa se dedicar mais profundamente à parte das atividades do Conselho. Kose e Senbet (1998) concordam com Menon e Williams (1994), afirmando que o uso de comitês permite facilitar a avaliação e ratificação dos investimentos e decisões, melhorando o monitoramento do desempenho da gestão pelo Conselho.

Portanto, os próximos tópicos visam explorar as atividades exercidas pelos principais comitês uma vez que estes são grupos especializados que auxiliam o Conselho de Administração a supervisionar as atividades dos gestores da organização.

\subsubsection{Comitê de Auditoria}

Segundo Menon e Williams (1994) o Comitê de Auditoria é uma recomendação do Committe

of Sponsoring Organizations of the Treadway Commission ${ }^{7}$. Apesar de ser uma recomendação, a sua adoção voluntária é ampla, mesmo pelas organizações de capital fechado. Turley e Zaman (2004) divergem de Menon e Williams (1994) ao afirmarem que o Comitê de Auditoria não é uma estrutura nova nas organizações, mas sua adoção e aceitação como estrutura de governança corporativa aumentou enormemente nos últimos anos, decorrente principalmente dos escândalos descobertos por volta do ano 2000 .

\footnotetext{
${ }^{7}$ Committe of Sponsoring Organizations of the Treadway Commission: é uma organização voluntária privada, cujo objetivo é prover recomendações sobre aspectos críticos relacionados à governança, ética, controles internos, gestão de riscos, controle de fraudes e relatórios financeiros para executivos e órgãos de governança.
} 
Bradbury (1990) e Carson (2002) corroboram o que diz Turley e Zaman (2004) ao destacar que o Comitê de Auditoria é uma estrutura recomendada pela Securities Exchange Commission (SEC), desde 1940; e que desde 1977, sua adoção é mandatória no regulamento de empresas listadas na Bolsa de Nova York (Nyse). Os autores recomendam a não participação de executivos da empresa nesse Comitê e destacam a exigência do regulamento da Nyse, que somente conselheiros independentes componham este Comitê.

Pucheta-Martínez e Fuentes (2007) apresentam duas linhas principais de estudos relacionados ao Comitê de Auditoria. A primeira linha estuda a eficácia deste Comitê em relação a variáveis como mudança de empresa de auditoria, apresentação de ganhos e litígio entre os acionistas. Mas os autores afirmam que estes estudos são inconclusivos, não identificando situações ou relações em que o Comitê de Auditoria adiciona valor para uma organização.

A segunda linha de pesquisa apresentada por Pucheta-Martínez e Fuentes (2007) relaciona a estrutura interna e funcionamento do Comitê de Auditoria com premissas sobre sua eficiência. Segundo os autores, estes estudos apresentam evidências que relacionam a eficácia do Comitê de Auditoria a diversas variáveis, como qualidade dos membros deste Comitê e presença de membros com experiência na área financeira. Estes estudos também relacionam a independência do Comitê de auditoria com a presença de conselheiros externos, qualidade dos relatórios financeiros e comitês cooptados pela gestão.

Van Gansbeke et al (2008) estudam a composição, a frequência das reuniões e as tarefas do Comitê de Auditoria, além da relação desta estrutura com o Conselho de Administração, Auditoria Externa e Auditoria Interna. Estes autores destacam a presença da ênfase na confidencialidade em todos os códigos de governança corporativa relacionados na pesquisa e a ausência de estabelecimento de número mínimo de reuniões deste Comitê.

Em Van Gansbeke et al (2008) é pesquisada a relação entre o Comitê de Auditoria e a Auditoria Externa e Interna, Conselho de Administração e Gestão e a eficácia e qualidade dos relatórios financeiros e da governança corporativa. Os autores entendem o Comitê de Auditoria como um subconjunto do Conselho de Administração. 
Para Bradbury (1990), o Comitê de Auditoria colabora na regulação das corporações através da monitoração da alta gestão, estabelecendo a comunicação entre o Conselho e as áreas de controle interno e externo da empresa. $\mathrm{O}$ autor destaca como resultados da adoção deste Comitê o aumento da credibilidade dos relatórios financeiros, o auxílio ao Conselho de Administração em suas responsabilidades e o aumento da independência dos auditores externos. Entretanto, reconhece a necessidade de membros com conhecimentos especializados em finanças para o alcance destes resultados.

Turley e Zaman (2004) entendem que o Comitê de Auditoria deve monitorar a veracidade das informações, processos de contabilidade e cumprimento às leis e padrões éticos. PuchetaMartínez e Fuentes (2007) seguem a visão de Turley e Zaman (2004) ao afirmarem que o Comitê de Auditoria é uma estrutura delegada pelo Conselho de Administração para salvaguardar o interesse dos acionistas através de mecanismos de monitoração das informações financeiras. Estes autores concluem que este Comitê possui papel considerável na redução de assimetria de informações entre "insiders" e "outsiders" da organização.

Turley e Zaman (2004) veem o Comitê de Auditoria como uma estrutura com potencial contribuição na relação entre conselheiros, investidores, auditores independentes e a contabilidade da organização. Dentre os benefícios do Comitê de Auditoria, Menon e Williams (1994) destacam o monitoramento dos gestores, maior transparência na seleção da auditoria independente e a supervisão do processo de auditoria, assegurando a integridade dos relatórios financeiros. Como decorrência destes benefícios, os autores destacam a maior independência e eficiência do Conselho e das Auditorias Externas. Para Turley e Zaman (2004), este comitê deve também comentar e aprovar as políticas de contabilidade da organização e influenciar na transparência dos relatórios financeiros.

Van Gansbeke et al (2008) afirmam que o número de membros do Comitê de Auditoria deve ser definido pelo balanceamento de diversos fatores como custos, agilidade na tomada de decisões, coesão, qualidade dos relatórios financeiros e independência dos membros em relação à gestão. Turley e Zaman (2004) complementam enfatizando a necessidade de balanceamento de poder entre a contabilidade e auditoria como fator crucial para o sucesso do Comitê de Auditoria. 
Pucheta-Martínez e Fuentes (2007) evidenciam que a adoção do Comitê de Auditoria aumenta a qualidade e acuracidade das informações financeiras pela redução de erros e não cumprimento às leis e normas. Estes autores também encontram uma relação inicialmente positiva e posteriormente negativa entre o tamanho do Comitê de Auditoria e a qualidade dos relatórios financeiros. Van Gansbeke et al (2008) também evidenciam uma relação positiva significante entre o número de membros deste Comitê e a qualidade dos relatórios financeiros e independência da gestão.

Outra evidência apresentada em Pucheta-Martínez e Fuentes (2007) é a relação positiva entre o tamanho da empresa e a qualidade dos relatórios financeiros. Van Gansbeke et al (2008) identificam também uma relação positiva entre a qualidade de conhecimento financeiro dos membros do Comitê de Auditoria e independência em relação à gestão, como destacado em Bradbury (1990).

Van Gansbeke et al (2008) relacionam códigos de Governança Corporativa sem sugestão de número mínimo de membros a organizações com Comitês de Auditoria formados por poucos membros. Inclusive, relacionam códigos de Governança sem a prescrição do número mínimo de reuniões do Comitê de Auditoria com empresas, as quais tendem a organizar mais reuniões deste Comitê em comparação a organizações que seguem códigos com sugestão da quantidade mínima de reuniões.

Entretanto, Pucheta-Martínez e Fuentes (2007) não evidenciam no contexto espanhol a relação entre a composição do Comitê de Auditoria e transparência em relação à incerteza. Os autores também não encontram relação significante entre a quantidade de membros do Comitê de Auditoria que representam grandes acionistas e a qualidade dos relatórios financeiros, mas evidenciam a relação positiva entre a independência do Comitê com a qualidade dos relatórios financeiros.

Menon e Williams (1994) afirmam que a falta do Comitê de Auditoria nas empresas não significa necessariamente a falta de monitoramento dos atos da gestão. Esta afirmação é compartilhada por Bradbury (1990), pois segundo este autor, a obrigatoriedade da adoção desta estrutura pode gerar custos inconsistentes para as empresas. Menon e Williams (1994) e Carson (2002) também destacam que o Comitê de Auditoria pode ser adotado apenas para formar uma imagem de boa governança corporativa, sem grande utilidade para a organização. 
Devido ao Comitê de Auditoria ser uma estrutura de monitoramento das atividades dos gestores, que assegura a integridade dos relatórios financeiros da organização e possui comunicação tanto com o Conselho de Administração como com a gestão, pode desempenhar um papel ativo na gestão de risco da corporação. Pois os membros desta estrutura, ao realizarem suas atividades para monitorar os gestores e assegurar a integridade dos relatórios financeiros, terão condições de averiguar se os níveis de apetite e tolerância a riscos ${ }^{8}$ estabelecidos pelo Conselho são respeitados pelas estruturas de gestão.

\subsubsection{Comitê de Riscos}

Yatim (2010) considera o conceito de gestão de risco central para a governança corporativa e afirma que a gestão de risco tornou-se um dos principais focos para os Comitês do Conselho de Administração. Atkinson (2008) atribui ao Conselho de Administração a responsabilidade da supervisão dos riscos no nível de controle enquanto a implantação e execução da gestão dos riscos devem ser exercidas pela gestão da empresa. Em Aldred (2003) é destacado duas formas como as organizações lidam com a gestão de riscos: há empresas que adotam o Comitê de Risco para supervisionar a gestão dos riscos da organização enquanto outras lidam com estes riscos através da criação da Diretoria de Riscos (CRO - Chief Risk Officer).

Uma terceira forma é apresentada em Yatim (2010), Atkinson (2008) e Bates e Leclerc (2009), que consiste no uso do Comitê de Auditoria para a supervisão dos riscos da organização. Entretanto, estes autores apresentam questionamentos sobre a eficácia deste Comitê para o controle dos riscos da empresa. Yatim (2010) e Atkinson (2008) questionam se o conhecimento necessário aos membros do Comitê de Auditoria são também os conhecimentos necessários para a gestão de risco corporativo. Atkinson (2008) complementa a crítica afirmando que os Comitês de Auditoria possuem outras atividades, por isso, responsabilizá-los pela gestão de risco corporativo pode sobrecarregá-los de atribuições e responsabilidades.

\footnotetext{
${ }^{8}$ COSO (2004, p. 43) define tolerância ao risco como "nível aceitável de variabilidade na realização das metas e objetivos definidos".
} 
Bates e Leclerc (2009) afirmam que no contexto norte-americano, o Comitê de Riscos é mais frequente em setores regulados. Atkinson (2008) complementa o panorama de ação deste Comitê ao afirmar que nos Estados Unidos, esta adoção ocorreu principalmente devido à popularidade do conceito de gestão corporativa de riscos e por requisitos da Bolsa de Valores de Nova Iorque (Nyse). Porém, o autor destaca que a adoção deste Comitê ainda está na sua fase inicial.

Bates e Leclerc (2009) abordam a existência de dúvidas sobre a relação entre a melhora do controle da organização pelo Conselho de Administração e a adoção do Comitê de Riscos, pois consideraram difícil a mensuração da eficácia deste Comitê.

Yatim (2010), por sua vez, evidencia que há relação significativa entre a adoção do Comitê de Risco e o comprometimento do Conselho de Administração com o desempenho da governança corporativa da organização. Ressalta, também, que há uma relação positiva entre a adoção do Comitê de Risco com o tamanho e complexidade da organização e com a presença das grandes empresas de auditoria. Outra evidência apresentada pelo autor é a relação entre a adoção do Comitê de Risco com as estruturas de governança corporativa, com destaque para a relação positiva entre a adoção do Comitê de Risco e a presença de membros externos no Conselho de Administração e Conselhos que não tenham o presidente da empresa como membro.

Para Yatim (2010), a adoção do Comitê de Risco poupa o tempo do Conselho de Administração e permite que este último foque no controle da empresa de forma mais ampla. Bates e Leclerc (2009) também indicam que o uso do Comitê de Riscos apresenta benefícios para o Conselho de Administração, pois entendem o Comitê de Risco como uma estrutura com foco exclusivo na Gestão do Risco Corporativo, permitindo que o Conselho de Administração foque em questões mais amplas, relacionadas ao controle da empresa, provendo maior flexibilidade a esta estrutura para lidar com tendências e eventos que possam afetar a organização.

Contudo, Bates e Leclerc (2009) alertam que mesmo após a adoção do Comitê de Riscos corporativos, o Conselho de Administração continua responsável pela supervisão destas atividades. 


\subsubsection{Conselho Fiscal - uma característica brasileira}

O Conselho Fiscal é uma estrutura característica da governança corporativa no Brasil. Segundo Escuder e Tinoco (2008) e Gorga (2007), esta estrutura é uma exigência legal, instituída pela Lei 6.404/76, com modificações pelas Leis 9.457/97 e 10.303/01, com o objetivo de reduzir o conflito entre acionistas majoritários e minoritários.

Seus objetivos são: promover maior transparência das informações e acesso aos atos da gestão para os acionistas minoritários. Alencar (2008) acrescenta que a lei 6.404/76 também prevê as competências necessárias para os ocupantes dos cargos do Conselho Fiscal, ao que Trapp (2009) e Furuta (2010) adicionam que a existência desta estrutura é obrigatória, mas não necessariamente permanente.

As funções do Conselho Fiscal, segundo Escuder e Tinoco (2008), estão ligadas ao acompanhamento dos controles internos. Dentre as atividades citadas pelos autores está o acompanhamento do planejamento estratégico e de decisões relevantes para a empresa, além de fazer parte do controle e fiscalização da alta gestão. Segundo os autores, estas atividades possuem o efeito de proteção aos acionistas minoritários e ao mercado de capitais.

Alencar (2008), Trapp (2009) e Furuta (2010) destacam da referida lei que os membros do Conselho Fiscal são eleitos em assembleia pelos acionistas e suas atividades consistem em:

- fiscalizar os atos administrativos, verificando o cumprimento dos deveres legais e estatuários;

- emitir opinião sobre os relatórios anuais e sobre propostas da administração;

- denunciar crimes e fraudes; e

- convocar assembleia extraordinária quando a administração retardar em mais de um mês a convocação da assembleia ordinária.

Furuta (2010) aponta que o Conselho Fiscal, por ser eleito pelos acionistas, é independente da Diretoria e do Conselho de Administração. Trapp (2009, p. 104) entende o Conselho Fiscal como um instrumento de controle e informação, pois considera a especialização do 
Conselheiro Fiscal como "item diferencial para a melhoria das informações contábeis divulgadas".

Escuder e Tinoco (2008), Alencar (2008) e Furuta (2010) apresentam a estrutura conhecida como Conselho Fiscal Turbinado ou Conselho Fiscal Adaptado, que consiste na estrutura original do Conselho Fiscal com modificações para atender a requisitos da Sarbanes-Oxley act (SOX). Segundo os autores esta modificação é adotada por parte de empresas brasileiras que possuem títulos de American Depositary Receipts (ADR) negociados no mercado norteamericano. Escuder e Tinoco (2008) consideram que o papel do Conselho Fiscal foi fortalecido pela decisão da SEC em aceitá-lo como equivalente ao Comitê de Auditoria.

Alencar (2008) e Furuta (2010) destacam conflitos e sobreposição de atividades oriundos desta modificação do Conselho Fiscal devido a conflitos entre a legislação brasileira e a norteamericana. Estes conflitos são relacionados às atividades do Conselho Fiscal e do Comitê de Auditoria, pois nem todas as atividades do Comitê de Auditoria são exercidas pelo Conselho Fiscal no Brasil. Desta forma, os autores entendem que tais estruturas não são substitutas, mas complementares, porém a adoção de ambas aumenta os custos de agência da organização.

\subsubsection{Comitê de Remuneração}

Segundo Anderson e Bizjak (2003), a compensação é um elemento-chave para a atração e manutenção de gestores de qualidade, provendo motivação para que estes desempenhem suas atividades. Carson (2002) considera que a determinação do pacote de remuneração está entre os processos que apresentam maior evidência do conflito de interesses entre acionistas e gestão.

A formação do pacote de compensação pode ser delegada ao Comitê de Compensação, também chamado de Comitê de Remuneração. Para Anderson e Bizjak (2003) e Carson (2002), este Comitê desenvolve os pacotes de remuneração tanto para atrair e manter os gestores como para alinhar o interesse destes aos dos acionistas. Conyon e He (2004) entendem que o Comitê de Remuneração possui papel significante na defesa dos interesses dos acionistas. 
Devido ao papel do Comitê de Remuneração é recomendado que este não possua membros da Diretoria Executiva, pois a presença de executivos da empresa pode ser entendida como um sinal de autoconcessão de benefícios. Anderson e Bizjak (2003) evidenciam uma relação positiva entre presença de membros externos neste Comitê e pacotes que envolvem menores salários com mais benefícios baseados em desempenho. Esta relação também é observada por Conyon e He (2004) quando há presença considerável dos acionistas neste Comitê.

Outra observação realizada por Conyon e He (2004) são os pacotes de remuneração elevados como decorrência da baixa qualidade dos membros do Comitê de Remuneração. Segundo os autores, o efeito pode derivar do interesse destes membros em preservar suas posições no Comitê ou da influência do chief executive officer (CEO) em sua atuação. Os autores também destacam que a diversidade neste Comitê favorece sua qualidade e dificulta a cooptação dos membros pela gestão.

Uma fraqueza do Comitê de Remuneração identificada por Conyon e He (2004) é a presença do problema de agência em três camadas. Segundo os autores, este problema ocorre quando o principal nomeia um supervisor para monitorar o agente. O resultado dependerá do alinhamento de interesses entre este supervisor e as outras duas partes da relação. Caso os interesses do supervisor estejam mais próximos dos do agente do que dos interesses do principal, este último será prejudicado. Portanto, os interesses dos membros do Comitê de Remuneração influenciam a facilidade de cooptação destes pela gestão, podendo acarretar em comprometimento da eficácia deste Comitê.

\subsubsection{Comitê de Nomeação}

De acordo com Carson (2002) e Ruigrok et al (2006), o Comitê de Nomeação é responsável pela identificação das competências necessárias para os cargos do Conselho de Administração e os candidatos para estes cargos. Outra atividade citada por Carson (2002) é a revisão periódica do desempenho dos executivos. Segundo Ruigrok et al (2006) este Comitê é subordinado ao Conselho de Administração. 
Carson (2002) identifica evidências de que processos de seleção ad hoc permitem maior influência dos executivos atuais da organização nos processos realizados por este Comitê, podendo enfraquecer seu desempenho. Ruigrok et al (2006) identificam uma relação positiva entre a adoção do Comitê de Nomeação e a presença de conselheiros externos no Conselho de Administração.

Até o momento foram exploradas: a necessidade da Governança Corporativa para controle dos dirigentes das organizações, as principais evidências de ações oportunistas e as principais medidas e estruturas utilizadas para mitigar estas ações oportunistas. Entretanto, estas ações e estruturas de governança podem apresentar diferentes objetivos por conta da visão que os sócios ou conselheiros da organização adotam. Em decorrência disso, nas próximas seções, são resumidas as principais visões da disciplina de Governança Corporativa.

\subsubsection{Demais grupos interessados na organização}

Tirole (2006) apresenta uma visão que contempla outros grupos interessados no desempenho da empresa, classificando-os como stakeholders. Segundo essa visão, denominada Stakeholder Theory, a empresa deve balancear os interesses dos proprietários com os interesses destes outros grupos.

Nesta teoria, segundo Hill e Jones (1992), todos estes grupos possuem contratos com os gestores da organização, portanto os gestores são agentes de todos os stakeholders. Destacam também que estas relações não devem ser vistas como as relações descritas pela Teoria da Agência. Apontam que os interesses dos stakeholders devem ser satisfeitos, pois estes grupos são fornecedores de recursos críticos ou de investimentos específicos para a organização. Classificam como stakeholders de uma organização seus empregados, clientes, fornecedores, credores e a comunidade. Donaldson e Preston (1995) compartilham desta visão ao afirmarem que a corporação é uma constelação de interesses cooperativos e competitivos, cujos interesses são legítimos.

Hill e Jones (1992) também declaram que a satisfação dos interesses dos stakeholders reduz a quantidade de recursos disponíveis para expropriação pelos gestores. Entretanto, para que estes interesses sejam atendidos, é necessário o comprometimento da gestão com esses 
grupos, e que os grupos monitorem os gestores. Donaldson e Preston (1995) alertam que embora os interesses destes grupos sejam legítimos, os gestores não devem envolvê-los de forma igual em todos os processos e decisões. Hill e Jones (1992) afirmam que as instituições são mecanismos que podem auxiliar no alinhamento de interesses entre gestores e os stakeholders.

Donaldson e Preston (1995) consideram que esta visão estabelece múltiplos objetivos que nem sempre são congruentes, porém cabe ao gestor balanceá-los para garantir o futuro da organização. Um possível distúrbio que esta visão pode causar, segundo Tirole (2006), é a perda de foco da organização, pois os gestores devem conciliar diversos objetivos que podem ser conflitantes. Neste contexto, abre-se espaço para o gestor cometer abusos em beneficio próprio, baseando suas ações oportunistas nesses objetivos conflitantes. O autor também considera que esta visão reduz os incentivos dos investidores, pois este grupo dividiria a propriedade da organização com os demais stakeholders.

Jensen (2001) estende as críticas de Tirole (2006) sobre a Stakeholder Theory, afirmando que é impossível a tomada de decisão racional e a maximização de valor com objetivos que apontam para diversas direções. Para o autor, as falhas nesta teoria estão em não especificar o objetivo da empresa e nem em como os gestores devem realizar os trade-offs entre os interesses dos diversos grupos. Segundo o autor, esta pluralidade de critérios torna os gestores unaccountables, resultando em aumento nos custos de agência na organização.

\subsubsection{Maximização do valor da empresa como meta dos gestores}

Jensen (2001) entende como critério de sucesso da organização e consequentemente de avaliação dos gestores a sobrevivência da organização no longo prazo. Contudo, o autor também considera o atendimento das demandas de outros stakeholders, além das demandas dos acionistas e credores, como fundamentais para a sobrevivência da empresa. Desta forma, Jensen (2001) propõe uma teoria formada a partir da Teoria da Agência e da Stakeholder Theory, cujo objetivo da gestão é maximizar o valor da empresa no longo prazo ao invés de atender o interesse de qualquer grupo de stakeholders, chamando esta teoria de Enlightened Stakeholder Theory, e considera que a maximização do valor da empresa é o critério que a gestão deva utilizar para realizar os trade-offs entre os interesses dos diversos stakeholders. 
Portanto, o papel do Conselho de Administração é monitorar a gestão para garantir que os gestores tomem medidas que visem à maximização do valor da empresa. Dentre estas ações está a gestão de riscos da organização, pois a gestão de riscos pode contribuir com uma alocação mais eficiente de recursos da organização, adequando o nível de exposição a riscos desta organização ao nível desejado dos proprietários.

No contexto dos intermediários do mercado de capitais, os Conselhos destas organizações devem considerar também como partes interessadas os órgãos reguladores, as empresas negociadas em seus mercados, os participantes destes mercados e a economia do país.

Abordadas a necessidade de supervisão dos gestores de organizações resultantes da associação de diversos indivíduos e as principais medidas e estruturas utilizadas nesta supervisão, o próximo item possui foco na gestão de riscos, com ênfase na gestão de riscos corporativos; cujo objetivo é apresentar um corpo de teoria que auxilie na análise e entendimento de como ocorrem a gestão e a supervisão dos riscos da organização estudada e como são transmitidas entre os participantes destes processos as informações e percepções necessárias ou pertinentes.

\subsection{Gestão de riscos}

Simkins e Ramirez (2008) citam evidências que sugerem que a gestão de riscos era praticada na Índia por volta de 2000 a.C., entretanto, os princípios de gerenciamento de riscos datam da época da Grécia Clássica e do Império Romano. A gestão de risco em empresas é praticada normalmente em diversos departamentos dentro das organizações. Essa abordagem especializada levou ao desenvolvimento de três principais categorias modelos de gestão de risco: gestão de risco operacional, gestão de risco de mercado e gestão de risco de crédito.

Zonatto e Beuren (2010) apresentam uma gama maior de tipos de riscos, expandindo a classificação inicialmente composta por riscos operacionais, de mercado e de crédito adicionando os riscos estratégicos, de liquidez, legais e de imagem ou reputacional. Os resultados destes autores revelam outros riscos que são considerados pelas organizações: riscos ambientais, de revisão tarifária, patrimoniais, $\mathrm{P} \& \mathrm{D}$ e de produtos. 
Embora a gestão de risco dividida em silos tenha permitido a especialização e a construção de modelos sofisticados, ela não correlaciona estes riscos além de não contemplar outros riscos, como os reputacionais e os estratégicos. Outro ponto fraco da gestão em silos é a falta de sinergia entre as áreas.

Coimbra (2011) expande a classificação de riscos apresentada por Simkins e Ramirez (2008) ao classificá-los em riscos operacionais, riscos estratégicos e riscos financeiros; considera os riscos de mercado e de crédito como subconjuntos da categoria risco financeiro. Para ele, esta classificação auxilia a evitar a "miopia de risco" que ocorre quando os gestores desconsideram alguns tipos de riscos aos quais a organização está exposta.

\subsubsection{Gestão de risco nas organizações}

A gestão de risco dentro das organizações é tradicionalmente executada em silos, onde cada departamento possui modelos especializados. Neste contexto surgiu o conceito de gerenciamento integrado de risco, também conhecido como gestão corporativa de risco. Essa abordagem, entendida por alguns autores como uma evolução da gestão de risco em silos, traz uma abordagem holística, ou seja, os riscos são vistos de forma integrada para permitir o aproveitamento de ações de mitigação entre riscos relacionados, além de fornecer aos gestores e ao Conselho de Administração uma visão completa de todos, ou ao menos, dos principais riscos que a empresa está exposta. Entretanto, há uma lacuna entre especialistas em risco e o público geral, também chamado de leigo (em gestão de riscos). Essa lacuna deve-se à diferença de visões e assimetria informacional, causando diferenças na percepção sobre os riscos, o que pode despertar dúvidas e desconfianças entre as partes, dificultando a gestão eficaz e eficiente de riscos.

Para reduzir esta assimetria de informação entre os envolvidos, é necessária uma comunicação eficaz sobre risco. Esta comunicação deve permitir o fluxo de informação nas duas direções, de modo que os especialistas entendam as preocupações dos stakeholders leigos em gestão de risco e que estes últimos entendam as decisões tomadas pelo primeiro grupo. É esperada que a comunicação de risco eficaz reduza a assimetria de informação, reduzindo conflitos e estabelecendo uma visão integrada para todos os stakeholders. 
Em seu estudo, March e Shapira (1987) evidenciaram que executivos associam a palavra risco a possíveis resultados negativos de uma decisão ou evento, enquanto os resultados positivos são vistos como oportunidades por esse público. PRMIA (2009, p. 2) define risco como "circunstâncias futuras desconhecidas que podem alterar o valor ou o bem-estar de uma organização ou sistema", e evento de risco como "A ocorrência de circunstâncias especificas que reduzem, ou podem inesperadamente aumentar, o valor ou o bem-estar de uma organização ou sistema". Coso (2004) diz que riscos são eventos que produzem impacto negativo, destruindo valor ou criando obstáculos para a geração de valor. Para Burnaby e Hass (2009), risco é qualquer coisa que obstrui a organização de atingir seus objetivos.

No Guia IBGC (2007, p. 11), confirma-se a presença da visão apresentada por March e Shapira (1987) ao dizer que executivos e conselheiros comumente entendem risco como "a possibilidade de algo não dar certo", mas neste trabalho é apresentada a definição: "risco envolve a quantificação e qualificação da incerteza, tanto no que diz respeito às perdas como aos ganhos, com relação ao rumo dos acontecimentos planejados”. Já Simkins e Ramirez (2008) associam a palavra risco à combinação de oportunidades e perigos.

Tanto Coso (2004) como PRMIA (2009) e também Burnaby e Hass (2009) compartilham da visão dos executivos evidenciada por March e Shapira (1987), associando à palavra risco o sentido de evento que destrói valor. Já o IBGC (2007) e Simkins e Ramirez (2008) apresentam uma definição mais próxima da apresentada por Knight (1957).

Conforme evidenciado por March e Shapira (1987), por meio de entrevistas e pelos testes realizados por Tversky e Kahneman (1992), os tomadores de decisão no ambiente de risco são incapazes de identificar todos os riscos possíveis ou mesmo de avaliar todas as probabilidades de um risco identificado. Assim, pode-se entender risco como a exposição a situações ou eventos identificados que possuem diversos retornos possíveis, sendo parte desses retornos e suas probabilidades de ocorrência conhecida ou estimada.

A definição de risco é importante para estabelecer os objetivos do gerenciamento de risco. Embora existam diversas definições para o conceito de gestão de riscos, as principais apresentam as seguintes características: 
- Conhecimento ou estimativa dos possíveis resultados, positivos e negativos, além da estimativa da probabilidade de cada retorno.

- Uso desse conhecimento para tomar uma postura estratégica no lugar da postura defensiva ou passiva.

- Adequação da exposição ao risco de acordo com o apetite e tolerância ao risco com base no resultado desejado.

- Preparação de ações para a ocorrência dos eventos para maximizar os resultados positivos ou minimizar os impactos negativos dos eventos.

Nos próximos tópicos, é apresentada uma classificação para os principais riscos aos quais as empresas podem estar expostas, contextualizando a gestão de risco dentro de organizações do mercado financeiro.

\subsubsection{Riscos operacionais}

Para Bainbridge (2009), os riscos operacionais envolvem o modo como a empresa opera, ou seja, foca no seu ambiente interno. Exemplos dessa categoria de riscos são: fraude, falhas humanas e controles inadequados. Zonatto e Beuren (2010) também entendem que os riscos operacionais têm relação com o ambiente interno da empresa, processos internos e pessoas. Estes riscos surgem em decorrência da falta de consistência e adequação dos sistemas de controle interno e de sistemas de processamento de informações, o que pode ocasionar perdas inesperadas para a instituição.

Ferreira (2006) apresenta a definição de risco operacional do Bank for International Settlements (BIS) que indica este tipo de risco como perdas diretas ou indiretas devido à inadequação ou falhas de procedimentos, pessoas, sistemas de informação ou eventos externos.

Coimbra (2011) apresenta diversas definições para risco operacional, cujas principais características são a relação entre as atividades da empresa e seus resultados, principalmente devido a falhas ou atenção inadequada a controles inadequados, falhas de sistemas e eventos 
não gerenciados, falta de qualificação ou treinamento correto dos empregados e seus erros, sejam por acidentes ou mesmo intenção, como fraudes.

Oldield e Santomero (1997) afirmam que em instituições financeiras o risco operacional é relacionado a problemas oriundos de processamento, alocação, cálculos de pagamentos ou falhas no processamento das operações. Para Coimbra (2011), as instituições financeiras enfatizam menos os riscos operacionais do que os ricos financeiros, embora haja o reconhecimento de que os riscos operacionais foram responsáveis por enormes perdas em instituições financeiras.

Santos (2007) declara que o sistema legal influencia os negócios criando garantias aos credores, além de impor restrições a certas formas de atuação. Coimbra (2011) classifica estes riscos como riscos legais e entende que estes são um subconjunto dos riscos operacionais.

Para Zonatto e Beuren (2010), os riscos legais são relacionados com a possibilidade de perdas decorrentes de autuações que a empresa pode sofrer, que resultem em multas indenizatórias devido à inobservância de dispositivos legais ou regulamentais.

Santos (2007) apresenta diversas definições para o risco legal, cujas principais características são a possibilidade de ser multado por descumprimento de alguma ação legal ou regulação e a possibilidade da lei operar de maneira adversa aos interesses e objetivos da instituição. $\mathrm{O}$ autor também apresenta a definição de risco legal do Banco Central do Brasil (BACEN, 2011, s/p): "risco que uma parte sofra porque as leis ou regulamentações não dão suporte às regras do sistema de liquidação de valores mobiliários e também que as leis e regulações ou suas aplicações sejam pouco claras ou transparentes".

Por fim, Santos (2007) observa que nenhuma das definições apresentadas contempla o risco legal como alterações em leis ou regulações que criem condições desfavoráveis à organização.

\subsubsection{Riscos de modelo}

Derman (1996) afirma que muitas empresas do mercado financeiro baseiam suas decisões em modelos e que essa prática expõe as organizações a novos riscos. O autor, em conjunto com 
Berkowitz e O'Brien (2002), lembra que modelos são simplificações da realidade, logo, não são construídos para representar fielmente a realidade, mas apenas as características mais importantes para uma determinada finalidade; ambos afirmam que a construção ou o uso de modelos podem apresentar falhas, especialmente em situações complexas, como a modelagem de investimentos envolvendo um conjunto com muitos instrumentos financeiros complexos.

Para Hull e Suo (2002), o risco de modelo é gerado pelo uso inadequado dos modelos, como a especificação ou construção incorreta do próprio modelo ou estimativas incorretas de parâmetros. Estes autores entendem este tipo de risco como um subconjunto dos riscos operacionais de uma organização. Fender e Kiff (2004) complementam ao afirmarem que o risco de modelo é relacionado com a acuracidade dos resultados obtidos no uso de modelos, sendo influenciada pelo modelo e metodologia utilizadas e premissas assumidas.

Derman (1996) afirma que os usuários de um modelo devem entender como ele foi desenvolvido para entender quais são suas limitações e quais podem ser suas falhas. $\mathrm{O}$ autor enumera como principais falhas que geram risco de modelo:

- Não considerar todos os fatores ou variáveis relevantes que afetam o modelo.

- Assumir uma dinâmica ou relação incorreta para um ou mais fatores do modelo.

- O modelo pode ser inapropriado ou algumas de suas premissas inválidas em determinadas condições.

- Os dados utilizados nos modelos podem ser de baixa qualidade, como estimativas mal realizadas.

- A realidade que o modelo representa pode ser instável, o que pode invalidar o modelo com o passar do tempo.

- Quando o modelo é construído em um software, este pode ser desenvolvido com defeitos ou podem existir falhas no hardware que o executa.

Derman (1996) e Hull e Suo (2002) dizem que é possível reduzir o risco de modelo através de testes com dados históricos, e que esta técnica possui muitas limitações. Consideram também que a comparação entre diferentes modelos pode reduzir os riscos de modelo. Derman (1996) 
complementa alertando os usuários de modelos para averiguarem o motivo de qualquer discrepância, por menor que seja, quando estiverem homologando novos modelos.

\subsubsection{Riscos financeiros}

Coimbra (2011) afirma que há um relativo consenso sobre os tipos de riscos financeiros, principalmente devido à disseminação do entendimento pelos órgãos reguladores do setor financeiro. Para o autor, estes tipos de riscos apresentam as seguintes características:

- São relacionados às operações financeiras das organizações, vinculando-se a possíveis perdas no mercado financeiro.

- Podem ser divididos em risco de mercado, risco de crédito e risco de liquidez.

Para Zonatto e Beuren (2010), os riscos de mercado são aqueles relacionados aos investimentos financeiros que a organização realiza, sendo os riscos de perdas devido a oscilações de variáveis econômicas e financeiras. Coimbra (2011), por sua vez, diz que os riscos de mercado estão relacionados com as incertezas dos retornos esperados pelas operações financeiras realizadas pela organização em decorrência de variação de fatores de mercado como preços e taxas.

Zonatto e Beuren (2010) afirmam que o risco de liquidez é relacionado à capacidade da organização em honrar seus compromissos; origina-se no descasamento entre os níveis de ativo e passivo da organização, causando insuficiência de recursos para a empresa cumprir suas obrigações. O risco de liquidez está relacionado à incapacidade de uma organização liquidar seus ativos ou obter financiamento.

Coimbra (2011) relaciona definições para o risco de liquidez que apresentam como principais características a possibilidade do nível do passivo exceder o nível do ativo ou à impossibilidade de vendas de ativos em determinado período ligados à possibilidade da organização não obter recursos no mercado financeiro para honrar seus compromissos. $\mathrm{O}$ autor contextualiza o risco de liquidez no mercado financeiro citando definições em que o risco de liquidez é entendido como a possibilidade dos depositantes exigirem dinheiro à vista 
em troca de seus direitos financeiros, que pode gerar retiradas superiores ao usual, afetando a capacidade de solvência do banco.

Verrone (2007, p. 35) cita a definição de crédito de Santos (2000) como "a troca de um valor presente por uma promessa de reembolso futuro, não necessariamente certo, em virtude de fator risco". O autor entende que o risco de crédito ocorre porque estas promessas podem não ser pagas integralmente. Para Zonatto e Beuren (2010) o risco de crédito está diretamente relacionado ao grau de incerteza que as operações de crédito em que a organização cede capital temporariamente a terceiros serão honradas.

No contexto de instituições financeiras, Verrone (2007, p. 35) cita a definição do Comitê de Basileia que define risco de crédito como "o potencial que um tomador de crédito ou contraparte de uma instituição financeira venha a falhar em cumprir suas obrigações de acordo com os termos combinados".

Bainbridge (2009) define o risco de crédito como a possibilidade de mudança na qualidade de crédito da contraparte afetar o valor da organização. Jorion (1998) acrescenta que o risco de crédito pode ser originado também pela decisão da contraparte de não honrar seus compromissos.

Para Coimbra (2011, p. 33), risco de crédito é:

[...] a possibilidade de ocorrência de perdas associadas ao não cumprimento pelo tomador ou contraparte de suas respectivas obrigações financeiras nos termos pactuados, à desvalorização de contrato decorrente da deterioração na classificação de risco do tomador, à redução de ganhos ou remunerações, às vantagens concedidas na renegociação e aos custos de recuperação.

\subsubsection{Riscos estratégicos}

De acordo com Zonatto e Beuren (2010), os riscos estratégicos têm origem no ambiente em que a empresa está exposta e estão vinculados à forma de gerenciamento da atividade da empresa, que podem levar a perdas devido a estratégias adotadas, dinâmica dos negócios e concorrência. 
Schimit e Chao (2010) definem riscos estratégicos como os riscos que afetam a sustentabilidade e a viabilidade de uma organização como resultado de decisões estratégicas inadequadas, ou da implementação inadequada destas decisões pela gestão, por falta de resposta da gestão em relação a mudanças do ambiente externo ou interno da organização. Estes autores consideram que o conceito de risco estratégico não é percebido da forma adequada pelos gestores de bancos.

Para Coimbra (2011), ainda não há consenso ou entendimento sobre a definiç̧ão de riscos estratégicos. $\mathrm{O}$ autor elenca diversas definições para o risco estratégico que apresentam como principais características:

- Consequência de fatores externos relacionados a mudanças nos cenários econômicos ou políticos.

- Mudanças são de longo prazo que alteram o modo como a empresa adiciona valor aos stakeholders ou mesmo devastam a organização, como a entrada em novos mercados e ação de concorrentes ou clientes.

- Decorrentes das decisões estratégicas tomada pelos gestores.

\subsubsection{Riscos de imagem ou reputacionais}

Coimbra (2011) classifica os riscos de imagem ou reputacionais como um subconjunto dos riscos estratégicos. Este tipo de risco influencia diretamente no capital reputacional da organização, que é visto por Barzel e Suen (1997) como um dos capitais garantidores dos contratos da empresa.

Para Machado Filho e Zylbersztajn (2004), a integração de mercados e a disseminação de informações em tempo real aumentaram a importância do capital reputacional das organizações de modo que o crescimento e sobrevivência destas são afetados por sua reputação. Overbay (2004) corrobora a afirmação de Machado Filho e Zylbersztajn (2004) ao considerar a gestão da reputação corporativa como meio de proteger e criar valor para o acionista, assim como Murray (2003) que atribui grande importância à gestão do capital reputacional ao considerar este tipo de capital como de imenso valor financeiro. Schanz 
(2006) também considera a assimetria de informação relevante na formação da reputação de uma organização.

Power et al (2009) consideram o capital reputacional como estratégico e de difícil construção, pois os autores entendem que esta construção é baseada na comunicação entre a organização e seus stakeholders. Os autores alertam que as percepções das pessoas não refletem necessariamente a verdade, sendo sua formação influenciada principalmente por fatos sociais que geram ações de ação e reação na sociedade. Como resultado, este tipo de capital não está totalmente sob o controle da organização.

Decorrente da crescente importância do capital reputacional, Machado Filho e Zylbersztajn (2004) evidenciam que os executivos dedicam parcela considerável do seu tempo para gerir a identidade das empresas para qual trabalham. Xifra e Ordeix (2009) concordam com Machado Filho e Zylbersztajn ao afirmarem que o risco reputacional passou a ser tratado como uma nova categoria de risco, assim como Power et al (2009), que consideram a emergência do risco reputacional como uma categoria distinta dos demais tipos de risco um sintoma da moderna intensificação da organização e preocupação com a imagem organizacional; e complementam que este novo tipo de risco possui um papel de modelador do comportamento gerencial.

Murray (2003) entende que são as ações das pessoas ligadas à organização que definem sua reputação. Esta visão é compartilhada por Machado Filho e Zylbersztajn (2004), quando afirmam que este tipo de capital possui relações com questões éticas e com a responsabilidade social, permeando desde a qualidade dos produtos ou serviços da organização até práticas internas de RH ou o relacionamento com seus fornecedores.

Machado Filho e Zylbersztajn (2004, p. 88) definem o capital reputacional como "a porção de valor de mercado da empresa que pode ser atribuída à percepção que se tem da firma como uma corporação de boa conduta no mercado". Para estes autores, a reputação de uma organização é construída com base em quatro fatores: credibilidade, qualidade, responsabilidade e confiança. Schanz (2006) define a reputação como o conjunto duradouro das percepções, opiniões e expectativas dos stakeholders. 
Power et al (2009) consideram que o risco reputacional difere dos demais tipos de risco por ser puramente resultado de iteração social e comunicação. Xifra e Ordeix (2009) diferenciam risco de compliance de risco reputacional, explicam que o risco de compliance é a possibilidade de uma organização em falhar no cumprimento de regulações legais, regras em geral, padrões ou código de conduta aplicáveis a suas a atividades as quais podem resultar em sanções para a empresa. O risco reputacional, segundo os autores, emana da percepção que os stakeholders internos e externos têm da organização no desenvolvimento de suas atividades, incluindo os aspectos legais, econômico, financeiro, ético, social e ambiental.

Machado Filho e Zylbersztajn (2004) destacam algumas dificuldades relacionadas ao capital reputacional de uma organização, como a dificuldade em medir a reputação de uma firma e o resultado de uma informação imperfeitamente entendida sobre uma organização. Xifra e Ordeix (2009) apresentam a mesma dificuldade mencionada por Machado Filho e Zylbersztajn (2004), pois consideram a gestão do risco reputacional difícil de realizar devido à falta de métodos para classificar e medir este tipo de risco.

Overbay (2004) considera que boa parte das causas por trás dos riscos reputacionais são as mesmas já identificadas e tratadas nos programas tradicionais de gestão de risco. O autor concorda com Machado Filho e Zylbersztajn (2004) sobre os problemas de medir a reputação de uma organização ao destacar a dificuldade em mensurar os riscos reputacionais. Porém afirma que boa parte das perdas resultante de uma má reputação está relacionada à perda de confiança dos shareholders da empresa, indo de encontro com os fatores de construção da reputação organizacional destacados por Machado Filho e Zylbersztajn (2004). Murray (2003) também interpreta que a opinião de outras pessoas além dos acionistas pode alterar o valor da firma através de alterações em sua reputação.

Schanz (2006) considera as ameaças que a perda da reputação pode causar; e entende que a reputação é um ativo que pode ser gerido para oferecer retornos atrativos, mas lança questões sobre como a reputação de uma organização pode ser gerida; diz que devido ao capital reputacional ser baseado nas opiniões e percepções das pessoas, esta gestão deve ser direcionada pelas opiniões e percepções da sociedade. Power et al (2009) também ponderam a respeito da percepção das pessoas como um direcionador para a gestão do risco reputacional e acrescentam o papel da comunicação como crucial para a eficácia deste processo. 
Para Overbay (2004) uma solução efetiva para lidar com os riscos reputacionais deve possuir uma abordagem holística. Murray (2003) diz que a comunicação com os stakeholders é crucial na gestão do risco corporativo e destaca o papel do Conselho de Administração na gestão deste tipo de risco. Para o autor, o Conselho de Administração é responsável por assegurar os lucros da organização e os resultados para os acionistas de maneira sustentável, além de supervisionar as salvaguardas contra os riscos que podem causar danos à empresa ou ao seu futuro.

Schanz (2003) apresenta uma visão compartilhada por um grupo de especialistas que enfatizam determinados grupos de stakeholders que são considerados formadores de opinião. Outra visão apresentada pelo autor afirma que a gestão do capital reputacional deve possuir uma abordagem focando no tripple-bottom-line. $\mathrm{O}$ autor considera que as visões apresentadas evoluem convergindo para uma gestão da reputação que requer um balanceamento entre melhor desempenho da organização, melhor comunicação com stakeholders e implementação de políticas internas como governança corporativa e compliance.

Xifra e Ordeix (2009) descrevem práticas da gestão de risco reputacional de um grande banco internacional. Segundo os autores, nesta organização todos os novos produtos são avaliados por um comitê local e os aprovados são submetidos a um segundo comitê, porém internacional, para avaliar os riscos que o novo produto pode causar à imagem da organização. Além desses comitês, a organização utiliza profissionais externos à empresa para obter expectativas independentes sobre os mesmos produtos. Outra atividade da gestão de risco reputacional destacada pelos autores é a preparação das equipes de vendas de novos produtos. Estas equipes são preparadas para explicar corretamente todos os detalhes dos produtos, respeitando não somente as leis, mas também a ética e os costumes locais. Os autores também destacam o papel da comunicação na gestão do risco reputacional como uma ferramenta para comunicar valores e identidades, além de preocupações, atitudes e comportamentos relacionais ao risco em si.

Apresentadas as principais características da gestão de riscos e uma classificação de riscos contextualizada no mercado financeiro, nos próximos tópicos exploram-se as características da gestão corporativa de riscos, visando complementar a gestão de riscos em silos. 


\subsubsection{Gerenciamento corporativo de risco}

Além dos pontos não atendidos pela gestão de riscos em silos, Barton et al (2001) e KPMG (2003) citam novas forças no ambiente de negócios, como a globalização, a desregulamentação de setores, o uso da internet nos negócios e as mudanças nas expectativas dos consumidores como fatores que causaram grande impacto na gestão das empresas, e como essas organizações geram os riscos a que estão expostas, necessitando de uma abordagem integrada para a devida gestão.

Em Deloitte (2006) é apresentado que das 100 empresas que sofreram grandes perdas nos valores de suas ações no período entre 1994-2003, 37 foram devido somente a riscos financeiros enquanto as outras 66 foram devidos a riscos estratégicos. Das 100 empresas estudadas, $80 \%$ foram atingidas por dois ou mais riscos que eram inter-relacionados, reforçando a necessidade de uma gestão integrada de riscos.

Gates (2006) diferencia a gestão integrada de risco, também conhecida como gestão corporativa de riscos ou gestão de riscos corporativos, das demais pelas ações adotadas, pois enquanto a abordagem tradicional faz uso principalmente de seguros, swaps, hedges e outros recursos pontuais, a abordagem integrada foca-se na estratégia da empresa. Para Simkins e Ramirez (2008), a gestão corporativa de riscos é a evolução natural do processo de gestão de riscos, representando uma abordagem mais avançada e sofisticada; e apresentam a definição da Casualty Actuarial Society (CAS) que define o gerenciamento integrado de riscos como "processos pelos quais as organizações identificam, controlam, exploram financiam e monitoram os riscos de todas as naturezas com o propósito de aumentar o valor da organização, tanto no curto como no longo prazo, para seus stakeholders".

Conforme destaca PRMIA (2009), o gerenciamento integrado de risco não visa eliminar a exposição da organização a todos os riscos. Os processos e as medidas devem ser desenvolvidos para maximizar a relação retorno/risco e tentar transformar incertezas em risco, para que possam ser identificados, medidos e monitorados. Barton et al (2001) compartilham a visão apresentada em PRMIA (2009), destacando que o ERM deve mover a gestão de risco da empresa de defensiva para estratégica. Essa mudança de postura colabora para a eficiência da empresa e entendimento dos riscos fundamentais aos quais a organização está exposta, auxiliando os executivos a alcançarem os objetivos da organização. Já Burnaby e Hass (2009) 
afirmam que o gerenciamento integrado de risco deve primeiro desenvolver objetivos corporativos que sejam mensuráveis, para depois identificar os riscos que podem impedir o alcance desses objetivos, para finalmente identificar os controles que possam mitigar esses riscos.

Coso (2004) destaca que uma premissa do ERM é que toda empresa está exposta a riscos e que seu objetivo é prover valor para seus stakeholders. Para a entidade, o principal objetivo de um processo de ERM é determinar o nível de risco aceitável para que seja possível atingir o crescimento de valor desejado pelos stakeholders. Diz também que o valor da empresa é maximizado quando é obtido um equilíbrio ótimo entre crescimento / retorno e exposição aos riscos. KPMG (2003) compartilha da visão apresentada em Coso (2004) ao afirmar que o ERM é estruturado no alinhamento de estratégia, processos, pessoas, tecnologia e conhecimento com o propósito de criar valor através da gestão dos riscos que a empresa está exposta.

\subsubsection{Fatores de influência para adoção do ERM}

Liebenberg e Hoyt (2003), Kleffner et al (2003), Beasley et al (2005) e Pagach e Warr (2007) realizaram estudos para identificar os motivos que levam organizações a adotarem processos de ERM e quais características tornariam as empresas mais propensas a adotar essa prática.

Em todos os estudos é relatada a dificuldade em obter evidências confiáveis sobre a adoção do ERM. Devido a essa dificuldade, os estudos baseiam-se principalmente no anúncio público da criação do cargo de Chief Risk Officer (CRO - Diretor de Riscos) ou a contratação/nomeação de algum profissional para exercer esse papel. Embora seja um fator pouco preciso, é um dos poucos que esses autores julgaram confiáveis para separar empresas que adotaram o ERM das que não adotam.

Segundo os estudos citados, as principais fontes de influência para a adoção do ERM são a regulamentação imposta pelas bolsas de valores, por agências regulatórias governamentais, através de leis que regulamentam as empresas, e por membros do Conselho de Administração, principalmente os conselheiros independentes. Nota-se que em apenas um estudo surge a atividade de sócios institucionais como uma fonte de pressão para a adoção de ERM. 
Em contrapartida, os principais fatores que desencorajam a adoção do ERM são a estrutura e a cultura da empresa, além da dificuldade de medir o valor adicionado pelas práticas de ERM. Pelos estudos citados, é possível concluir que as influências para a adoção da gestão de risco têm origem principalmente em fatores externos à empresa, enquanto as barreiras têm origem em fatores internos.

Os estudos de Liebenberg e Hoyt (2003), Kleffner et al (2003), Beasley et al (2005) e Pagach e Warr (2007) procuraram relacionar algumas características das empresas com a propensão à adoção do ERM. Todos os autores concluíram que o tamanho da empresa e a alta volatilidade do preço de suas ações possuem relação positiva significante com a adoção destas práticas. Outro fator significante no contexto norte-americano é o setor da empresa, pois empresas dos setores financeiros, de seguros ou de setores que sofreram desregulamentação recente são mais propensas a adotar o gerenciamento de riscos do que as empresas dos demais setores.

Um resultado contraintuitivo apresentado em Pagach e Warr (2007) é a relação negativa entre o alto grau de dependência de P\&D criativa ou o alto potencial de crescimento com a propensão de adoção de práticas de ERM. Estes estudos também concluem que embora os fatores externos exerçam maior pressão para a adoção do ERM são os fatores internos que podem determinar a propensão ou não para a adoção dessas práticas.

Como principais resultados da adoção de práticas de ERM, Kleffner et al (2003) destacam o maior interesse e atenção dos conselheiros para os riscos que a empresa está exposta e a melhora da comunicação entre as áreas das empresas. Outro resultado evidenciado pelo estudo do citado autor é o melhor preparo da empresa para lidar com riscos, principalmente devido à criação de políticas de risco.

\subsubsection{Processos da gestão corporativa de riscos}

Para auxiliar a prática de gestão de riscos existem modelos desenvolvidos, dentre os quais se destacam o Integrated Framework (COSO, 2004), o modelo proposto pelo IBGC (2007) e os modelos apresentados por Burnaby e Hass (2009). Estes últimos consideram crucial o patrocínio da alta gestão para a implantação destas práticas. 
Para Ballou e Heitger (2005), o Conselho de Administração deve exercer papel de supervisor na gestão corporativa de riscos, enquanto os executivos são responsáveis pela implementação e execução desta gestão. Segundo Coso (2004) e Burnaby e Hass (2009) a definição do apetite e da tolerância a riscos devem ser desempenhadas pelos conselheiros e comunicadas aos executivos. Os executivos são responsáveis pela identificação dos riscos que a empresa está exposta. Porém essa atividade deve ser realizada por todas as áreas da organização, pois como explicam Burnaby e Hass (2009), uma comunicação ruim e o desconhecimento por parte dos executivos e conselheiros de riscos que a organização está exposta podem resultar em um "iceberg de riscos".

A etapa seguinte consiste na avaliação do impacto e da probabilidade de ocorrência de cada risco identificado. Gates (2006) recomenda que sejam hierarquizados os riscos para concentrar a atenção do Conselho e da gestão nos riscos mais importantes. Nesta etapa, também deve ser tomada uma decisão delicada: Como serão tratados os riscos com alto impacto para a organização, mas com baixa probabilidade de ocorrência? Pois conforme destacado por Bainbridge (2009), estes riscos representam ameaças à sobrevivência da empresa, mas não possuem distribuição conhecida, dificultando a análise e a decisão.

A partir da avaliação, deve-se decidir quais ações deverão ser tomadas para cada risco. Estas ações devem visar um dos seguintes objetivos:

- Eliminar o risco.

- Mitigar os efeitos ou reduzir a exposição da empresa ao risco.

- Compartilhar os impactos do risco com terceiros.

- Assumir as consequências do risco.

- Ampliar a exposição da empresa ao risco.

Decididas as medidas a serem tomadas para cada risco, estas devem ser operacionalizadas. A operacionalização pode ser divida em monitoração dos riscos e disparo de ações planejadas na ocorrência do evento. A monitoração deve ser um processo constante, realizado por todas as áreas da organização. 
Implantadas as medidas, torna-se necessário a elaboração de relatórios periódicos para prover feedback aos executivos e conselheiros sobre a situação de cada risco identificado, informando quais se materializaram, quais foram as ações tomadas e os resultados.

Nota-se que, embora a gestão integrada de riscos seja uma área relativamente nova, existem modelos e processos desenvolvidos, porém sua prática ainda é um desafio. Entretanto, estes modelos baseiam-se na definição do nível de risco e da tolerância ao risco aceitáveis pela organização, ponto que estes modelos não expõem em seus processos. Como consequência desta lacuna e da racionalidade limitada, a percepção do indivíduo é diferente da realidade, logo, estas definições podem ser errôneas, resultando em decisões equivocadas que podem comprometer o sucesso da organização, expondo-a a riscos desnecessários ou não desejados.

Estudos sobre percepção e comunicação de risco tentam identificar como as pessoas percebem os riscos e os julgam aceitáveis ou não. Portanto, parte da resposta a este problema pode estar no alinhamento da percepção de riscos dos indivíduos envolvidos na gestão de risco e na maneira como é realizada a comunicação dos riscos entre os tomadores de decisão e entre eles e demais partes interessadas na empresa.

Um caso emblemático que ilustra este problema ocorreu em Three Mile Island em 1979. Segundo Slovic (1987) e Kasperson et al (1988), após um vazamento de material refrigerante de um reator nuclear houve enorme pressão popular para aumentar a frequência de manutenção nesse tipo de usina. As manutenções nos reatores daquela usina, assim como de outras, eram realizadas na frequência recomendada pelos engenheiros, porém, por força da pressão popular, as autoridades políticas decidiram aumentar a frequência de manutenção. Entretanto essa medida aumentou o risco para a comunidade ao invés de reduzi-lo, pois o período de manutenção apresenta riscos extremamente superiores em relação aos do período de funcionamento. Como consequência, segundo especialistas, aumentou-se o risco de vazamentos ao invés de reduzi-lo.

\subsubsection{Percepção de risco}

Fischhoff (1984) apresenta uma classificação de risco baseada na percepção, separando-se em riscos objetivos e subjetivos. Os riscos objetivos têm origem na pesquisa cientifica por meio 
de estudos experimentais e análise probabilística. Os riscos subjetivos são percepções de não especialistas e baseiam-se em experiências, crenças e outros fatores sociais. Slovic (1987) e Renn (1990) identificam a separação apresentada por Fischhoff (1984) ao evidenciarem que especialistas empregam técnicas sofisticadas para análise dos riscos enquanto as demais pessoas, chamadas de leigas (em gestão de risco), utilizam julgamentos intuitivos que são tipicamente chamados de percepções.

Horlick-Jones (1998) apresenta uma classificação semelhante ao descrever o conflito acadêmico entre o lado "hard", baseado em cálculos de impactos e probabilidades e o lado, "soft" baseado em valores. Para o autor, a visão "soft" não confronta com a visão "hard", considerando essa divisão como inconsistente e reconhecendo a necessidade de uma nova abordagem que contemple as duas visões.

Há então dois conflitos originados por diferenças na percepção de riscos entre indivíduos. $\mathrm{O}$ primeiro ocorre entre especialistas e não especialistas, sendo a causa desse conflito a assimetria originada na diferença de conhecimento e linguagem utilizada pelos dois grupos. Estas diferenças podem resultar em ações que vão desde pressões equivocadas até o surgimento de desconfianças entre as partes. O segundo conflito ocorre entre os especialistas com vieses quantitativos ou qualitativos pela abordagem utilizada em suas análises, segundo Horlick-Jones (1998). O autor afirma que este conflito pode ocorrer no grupo de especialistas quando este é composto por pessoas com subculturas diferentes, resultando em diferença de opiniões sobre o melhor modo de conduzir uma gestão.

O fato dos especialistas "hard" utilizarem experiências e métodos analíticos, não significa que estão sempre corretos, pois como afirma Fischhoff (1984), em determinadas situações os indivíduos não especialistas podem ter melhor compreensão ou visão do que os especialistas. Já Renn (1990) afirma que tanto a percepção de especialistas como de não especialistas possuem méritos e limitações, devendo ser utilizadas como complementares. Outro ponto destacado por Fischhoff (1984), Renn (1990) e Horlick-Jones (1998) é a presença de vieses nas análises dos especialistas.

Segundo Reen (apud HORLICK-JONES, 1998, p. 82) a "análise de risco técnica não é necessariamente superior a qualquer outro constructo de risco porque ela é baseada em um grupo de convenções, interesses específicos de um grupo e julgamentos implícitos de 
valores". Horlick-Jones (1998) também destaca que mesmo utilizando considerável quantidade de conhecimento e julgamentos os profissionais envolvidos na gestão de risco necessitam de habilidades de improvisação e adaptação que são adquiridas somente na prática. Apresenta casos em que a crença em demasia nos especialistas durante a fase de identificação dos riscos e determinação do nível aceitável desses riscos levou a falhas. Nesses casos, a opinião dos especialistas foi valorizada em detrimento do conhecimento dos não especialistas, resultando em situações que o risco era percebido pelas pessoas, mas não considerado na gestão. A origem dessa falha, segundo o autor, foi a falta de contextualização na análise, ponto em que a visão dos não especialistas poderia ter contribuído para evitar estas falhas.

Portanto, no processo de gestão de riscos podem ocorrer conflitos entre especialistas e não especialistas devido a diferenças nas percepções sobre os riscos envolvidos. Enquanto os especialistas focam em magnitude de impacto e probabilidade, estudos sobre a percepção de risco dos não especialistas mostram que as preocupações deste público podem ser agrupadas em duas dimensões: o grau de desconhecimento ou a percepção de falta de controle sobre o evento e o nível de pânico que a possibilidade de ocorrência do evento causa no indivíduo.

Slovic (1987) complementa adicionando a dimensão de quantidade de pessoas expostas ao evento como um terceiro fator considerado por não especialistas. O autor também destaca que o grau de especificidade do risco possui pouca relação com a percepção dos indivíduos não especialistas.

Entretanto, Renn (1998) considera ilegítima a separação entre percepção técnica da leiga, sendo necessário para este autor e Horlick-Jones (1998) uma nova abordagem que aproveite as contribuições das duas percepções. Renn (1990) considera que uma gestão de risco responsiva e racional deve reconhecer as percepções dos dois grupos, considerando suas preocupações. Contudo, alerta que podem surgir problemas na gestão de risco devido a percepções que podem estar contaminadas por vieses.

Fischhoff (1984) destaca que as decisões sobre o nível de risco ou a tolerância de risco envolvem outros aspectos, como o valor a ser investido nessa decisão. Horlick-Jones (1998) acrescenta que é impossível desconsiderar o lado político em uma decisão sobre riscos, sendo apresentada uma situação que o tomador da decisão ou que partes interessadas desejam 
opções com menor nível de risco, mas essas opções podem não existir ou estarem indisponíveis a um preço aceitável.

Como principais contribuições do alinhamento da percepção de risco das diversas pessoas interessadas no processo de gestão de risco, Renn (1990) destaca o estabelecimento de valores e interesses para guiar o processo de balanceamento entre risco e retorno, a importância das dimensões qualitativas para a criação da estratégia de controles de risco e a contribuição para os programas de comunicação sobre risco entre os especialistas e não especialistas.

Slovic (1987) considera que há falta de informação sobre risco para as pessoas não especialistas; e que o entendimento de risco desse público é rico, refletindo preocupações normalmente omitidas nas análises dos especialistas. Como resultado, os esforços para conduzir o gerenciamento de risco e a comunicação de risco podem falhar caso não seja estruturado um processo de duas vias, de modo que especialistas e não especialistas possam contribuir.

\subsubsection{Comunicação sobre risco}

Plough e Krimsky (1987) consideram que até 1986 foram desenvolvidas poucas pesquisas relacionadas à comunicação sobre riscos. Porém, a partir daquele ano surgiram diversas discussões sobre o tema, relacionadas principalmente a questões sobre o meio ambiente e saúde pública. Segundo os autores, a comunicação sobre riscos era considerada um novo campo naquele momento, entretanto, consideram que essa prática é tão antiga quanto à cultura humana, uma vez que os seres humanos, durante sua evolução, estiveram expostos a uma enorme variedade de riscos e necessitaram se comunicar sobre estes riscos para sobreviverem.

Para os autores, a partir de 1986, a comunicação sobre riscos deixa de ser apenas um modelo e passa a ser um conceito utilizado por determinados grupos para atingir fins particulares. Consideram que a transição da conversa comum para uma comunicação especializada ocorreu devido a três fatores: o surgimento do Estado Moderno com responsabilidade sobre o bemestar social; o desenvolvimento de instituições públicas de saúde e a necessidade destas passarem para a sociedade informações sobre diversos riscos à saúde, como o consumo de água potável e leite pasteurizado; e a teoria de análise da decisão, que introduziu métodos 
quantitativos para a tomada de decisão, aplicando probabilidades para predizer e alterar o curso de ações na presença de riscos. Kasperson et al (1988) complementam que somente durante a Segunda Guerra Mundial foram introduzidas metodologias e modelos analíticos para realizar a análise e comunicação sobre risco. Esses métodos começaram a ser utilizados nas ciências sociais surgindo abordagens hibridas para dar suporte à tomada de decisão.

Segundo Plough e Krimsky (1987), a origem dos estudos deste tipo de comunicação não pode ser entendida sem considerar o conflito entre especialistas e o público em geral. Este conflito tem origem, como indicam estes autores, em questões ligadas à percepção do risco e à racionalidade humana, indo ao encontro dos conceitos de racionalidade limitada e capacidade de processamento limitada de Simon (1978 e 1986). Leiss (1996) complementa que este conflito pode ter origem na divergência de princípios ou abordagens, na assimetria de informações entre as partes ou em falhas, ao considerar o ponto de vista da outra parte; entende a comunicação sobre riscos eficaz entre as partes interessadas como um elemento vital para a gestão de riscos.

Kasperson et al (1988) afirmam que a análise de risco dos especialistas acata apenas probabilidades e impactos de consequências especificas, negligenciando outras características do risco consideradas pelo público. Desta forma, os autores destacam que a análise a partir do produto da probabilidade pelo impacto torna o especialista indiferente entre um evento de baixo impacto e alta probabilidade e outro evento de alto impacto e baixa probabilidade. Segundo os autores, o público tende a não concordar com este resultado.

Frewer (2004) cita as sensações de controle ou falta de controle da aceitabilidade do risco pelo público e dos elementos de risco e o potencial de catástrofe como características do risco, que são determinantes na percepção deste risco pelo público e na resposta deste sobre as políticas adotadas. Outra característica destacada por Kasperson et al (1988) é a presença de heurísticas e vieses na percepção de riscos do público como os vieses institucionais, os interesses econômicos e os reflexos culturais na percepção leiga de riscos.

Plough e Krimsky (1987) e Leiss (1996) entendem que a comunicação sobre riscos foi desenvolvida para gerir as diversas percepções sobre os riscos do público e dos especialistas, além do comportamento dos indivíduos em resposta à materialização de um risco. Um dos principais tópicos de pesquisa em comunicação sobre riscos apresentada por Kasperson et al 
(1988) é entender porque eventos avaliados por especialistas como secundários ou pouco preocupantes produzem impactos sociais extraordinários na sociedade. Leiss (1996) destaca como um dos objetivos da comunicação sobre riscos a melhora da qualidade do diálogo sobre riscos, reduzindo a distância entre especialista e público em geral para atingir o consenso em aspectos que inicialmente são controversos. Para Lasswell (2007) uma das funções da comunicação em uma sociedade é prover inteligência sobre as ações de um grupo.

Fischhoff (1995) afirma que em gestão de riscos é possível aprender com a experiência de outras pessoas ou organizações, porém o autor coloca como condição para o aprendizado que estas experiências devem apresentar tarefas ou riscos semelhantes à da situação enfrentada. Outro obstáculo à aprendizagem sobre gestão de risco a partir de experiências identificado pelo autor é a dificuldade de observar o processo ocorrido na situação que gerou a experiência. Bier (2001) afirma que as variáveis que influenciam a comunicação sobre riscos ainda não estão totalmente entendidas, além de considerar insuficientes as boas práticas existentes. Para o autor, faltam estudos que abordem a maneira de estruturar as mensagens e o processo de comunicação sobre riscos.

Plough e Krimsky (1987, p. 6) consideram que a comunicação sobre riscos é um conceito específico que foca na transferência de informações para responder a preocupações ou necessidades de públicos interessados, relacionadas a riscos reais ou percebidos. Estes autores atribuem duas definições para a comunicação sobre riscos: uma formal, utilizada na gestão de riscos, e outra simbólica, utilizada em discursos políticos. Na definição simbólica os autores afirmam que a comunicação possui ênfase no contexto social e seu principal objetivo é transmitir segurança e confiança para a aceitação das políticas adotadas. Nesta definição a informação técnica é secundária. Também apresentam a definição formal para a comunicação sobre riscos como "qualquer comunicação pública ou privada que informe aos indivíduos sobre a existência, natureza, forma, severidade ou aceitabilidade de riscos”.

Plough e Krimsky (1987) também consideram que a comunicação sobre riscos envolve a liberação controlada de informação para fins definidos, além de representar consequências não intencionais das mensagens sobre riscos. Leiss (1996) define a comunicação sobre riscos como o fluxo de informação e avaliação de riscos entre especialistas, reguladores, grupos com interesses e público em geral. 
Para Bier (2001) a comunicação sobre riscos visa os seguintes objetivos:

- Desenvolver confiança do público no comunicador.

- Aumentar o conhecimento ou a percepção dos riscos.

- Educar algum público sobre riscos.

- Atingir um acordo para a atuação sobre um risco.

- Motivar uma ação em relação a um risco.

O autor destaca que cada objetivo exige o uso de estratégias diferentes para a comunicação, mesmo que o objetivo final seja a transmissão de uma mensagem de sucesso do resultado de uma ação.

Plough e Krimsky (1987) propõem que o sucesso da comunicação de risco deve ser medida pelo grau em que as atitudes do público são refletidas na racionalidade dos especialistas e na medida em que o público compreende a análise dos especialistas. Assim, a comunicação de risco deve ser entendida como um problema de compreensão e aprendizagem mútua.

\subsubsection{Fases da comunicação sobre riscos}

Frewer (2004) afirma que inicialmente a comunicação sobre riscos possuía ênfase na comunicação direta sobre a aceitação de tecnologias, uma vez que os gestores de riscos entendiam que o público era ignorante em relação à probabilidade e técnicas de gestão de risco. Entretanto, esta abordagem resultou em desconfiança do público em relação às decisões tomadas pelos especialistas. Como resultado, o foco da comunicação sobre riscos mudou com o objetivo de restaurar a confiança do público na gestão de risco através de maior ênfase na consulta e participação do público e maior transparência das informações. O autor destaca como resultado desta abordagem o entendimento das preocupações do público por parte dos especialistas e de que suas análises deveriam considerar o contexto social. Em contrapartida o público começou a entender as análises dos especialistas e suas conclusões. 
Leiss (1996) baseado em Fischhoff (1995) descreve de forma semelhante a evolução da comunicação sobre riscos classificando-a em três fases.

A primeira fase aborda os aspectos quantitativos da estrutura de riscos, cuja análise resulta em prioridades para ações regulatórias. Nessa fase, as preocupações são estabelecidas com base somente em comparações quantitativas dos riscos. Uma abordagem, que segundo Fischhoff (1995), tornava difícil demonstrar que a análise executada pelos especialistas era adequada. Leiss (1996) complementa que essa abordagem contribuiu para estabelecer análises comparativas dos riscos, mas resultou na "arrogância dos especialistas" e no surgimento da desconfiança do público em relação a suas análises.

Na segunda fase da análise de Leiss (1996), o objetivo da comunicação sobre riscos era obter a credibilidade, transmitir a mensagem com clareza e utilizar de maneira efetiva os canais de comunicação, focando na necessidade e percepção da audiência. Porém, nessa fase a preocupação era somente de persuadir o público que os especialistas estavam corretos e não discutir as análises e resultados. Fischhoff (1995) acrescenta que a comunicação dos especialistas nesta fase limitava-se a explicar os números obtidos. $\mathrm{O}$ autor comenta outras duas principais falhas desta fase: a comunicação dos números era complexa e os especialistas esperavam que o público fosse tomador de decisão racional. Segundo Leiss (1996), a principal contribuição dessa fase é o reconhecimento da necessidade de uma comunicação eficaz sobre os riscos e da necessidade de um diálogo honesto e de esforços para entender as percepções do público.

A terceira fase da análise de Leiss (1996) é marcada pela falta de confiança do público nos especialistas e pelo início dos esforços dos especialistas em entender as percepções do público. Nessa fase, é identificado pelos especialistas que a confiança pode ser estabelecida lentamente por meio do comprometimento das instituições, com ações que realizem uma comunicação responsiva e consistente com o público. O público é reconhecido como um parceiro, sendo suas percepções e preocupações reconhecidas pelos especialistas. Bier (2001) concorda com Leiss (1996) ao afirmar que o compartilhamento de decisões entre especialistas e público aumenta a confiança entre estes atores. Outro ponto destacado pelo autor é a necessidade de comunicar o propósito da comunicação, seja compartilhar uma decisão ou somente informar sobre uma decisão já tomada ou algum fato ocorrido. 
Frewer (2004) afirma que nos estudos de comunicação sobre riscos há poucos relatos sobre a comunicação de incertezas e variabilidades. Um dos potenciais motivos apresentados pelo autor é que os gestores de riscos acreditam que comunicar incertezas para o público poderá trazer efeitos negativos para a percepção destes sobre os riscos. Outro motivo considerado pelo autor é a dificuldade em comunicar as incertezas de modo explícito e compreensível pela audiência. Entretanto, afirma que a comunicação sobre incertezas e variabilidade aumenta a confiança dos receptores nas fontes da informação. Portanto, este tipo de comunicação deve focar nas principais incertezas de modo a explicar ao público suas implicações na alocação de recursos da gestão além de prover informações sobre quais ameaças estão associadas a estas incertezas.

\subsubsection{Análise do processo de comunicação}

Lasswell (2007) apresenta duas abordagens para analisar o processo de comunicação. A primeira, representada na Ilustração 2, divide o ato da comunicação e a descreve a partir de respostas às perguntas "Quem?”, "Diz o quê?”, "Em qual canal?”, "Para quem?” e "Com qual finalidade?".

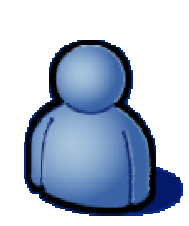

Quem?

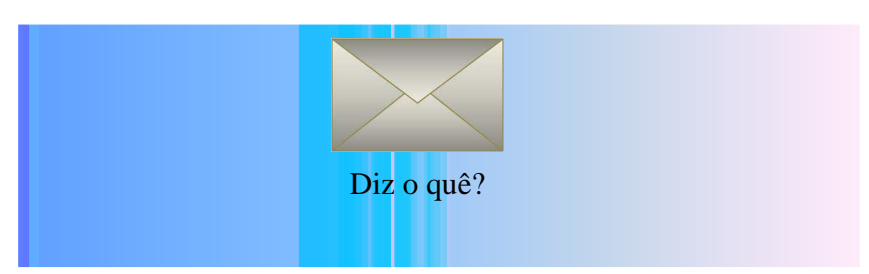

Em que canal?

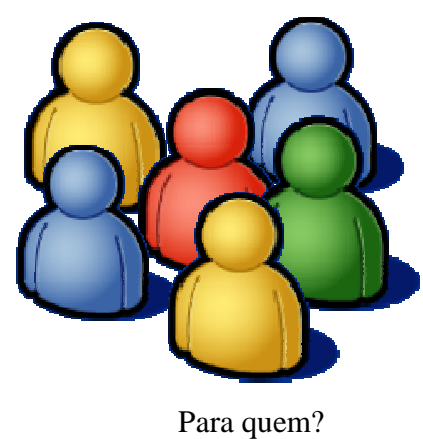

Com qual finalidade?

Ilustração 2 - Representação do modelo utilizado por Lasswell (2007) para entender o ato da comunicação

A segunda forma utilizada pelo autor procura entender a função da comunicação analisando o ato como um todo em relação ao processo social. Nesta abordagem, o autor analisa o fluxo da comunicação na sociedade através de cada indivíduo envolvido utilizando as seguintes perguntas: 
- Que informações atraem a atenção da pessoa?

- Quais informações a pessoa consegue passar da mesma maneira que recebeu?

- Quais informações o indivíduo perde?

- Quais informações ele altera ou suprime?

Na segunda abordagem, representada na Ilustração 3, o ato comunicacional é analisado para entender como ocorre a observação do ambiente, qual a correlação de cada parte da sociedade em resposta ao ambiente e como é transmitida a herança social entre as gerações. São identificados nessa análise três grupos de pessoas. O primeiro grupo é composto pelas pessoas que observam o ambiente e transmitem as informações às demais, o segundo grupo é composto pelas pessoas responsáveis pelas relações entre as respostas das instituições e o ambiente e o terceiro grupo reúne as pessoas que transmitem a herança social entre as gerações.

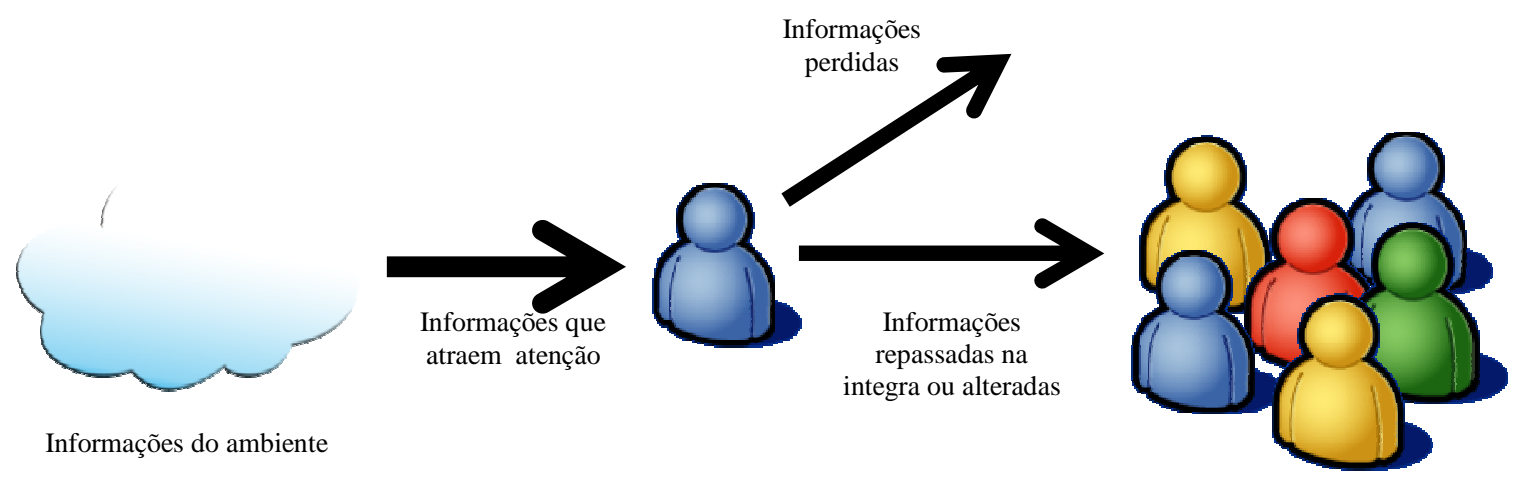

Ilustração 3 - Representação do modelo utilizado por Lasswell (2007) a comunicação como um todo

Para Bier (2001) a abordagem para analisar e estruturar a comunicação sobre riscos deve identificar os problemas mais importantes para o público para que se possam projetar as mensagens com estes problemas em mente. $\mathrm{O}$ autor recomenda uma abordagem semelhante à de Lasswell (2007) para preparar a comunicação sobre riscos. Para o autor, a comunicação deve ser planejada pensando em “Quem comunica?", "O quê?” e "Por quê?" para identificar as necessidades da audiência e evitar o entendimento limitado da mensagem. 
Conforme

representado

na

Ilustração 4 4, Plough e Krimsky (1987) destacam cinco componentes da comunicação sobre riscos: intenção, conteúdo, audiência, fonte e fluxo. Estes autores também consideram que a comunicação sobre riscos pode incorporar tanto objetos tácitos como explícitos na comunicação sobre eventos ou processos, porém os pontos centrais na comunicação são a intenção da fonte da mensagem e a qualidade da informação a ser transmitida. Bier (2001) complementa que as mensagens na comunicação sobre riscos podem ser limitadas devido a restrições legais, políticas da empresa e características da audiência.

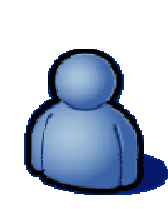

Fonte

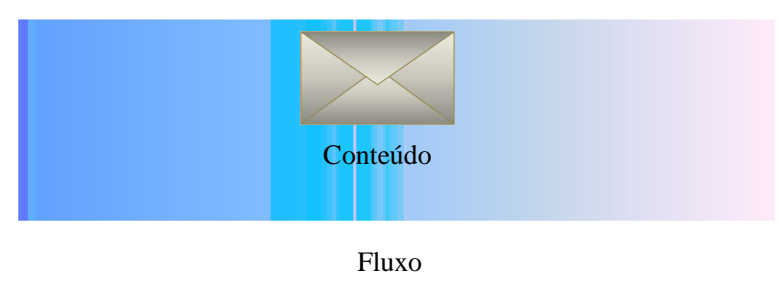

Intenção

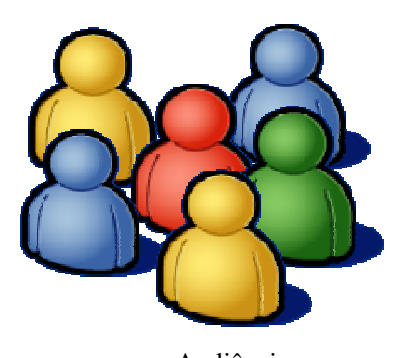

Audiência

Ilustração 4 - Representação do modelo apresentado em Plough e Krimsky (1987)

\subsubsection{Amplificação social de riscos}

Kasperson et al (1988) afirmam que eventos de risco interagem com processos psicológicos, sociais e culturais podendo realçar ou atenuar a percepção do público sobre os riscos e seu comportamento. A atenuação ou intensificação do sinal durante a comunicação é chamada pelos autores de amplificação e ocorre tanto na transmissão como na recepção da informação. Para eles, uma informação é um conjunto de sinais enviados pela fonte e estes sinais são decodificados pelos receptores para estes entenderem a mensagem. Durante esse processo o transmissor pode alterar, consciente ou inconscientemente, as mensagens através da amplificação, inclusão ou remoção de sinais.

Fischhoff (1995) acrescenta que a comunicação é iniciada antes que qualquer palavra seja dita; o desejo de comunicar algo já envia uma mensagem que pode ser amplificada pela suposição do que será dito, podendo causar problemas de desconfiança quando não há algo relevante para ser transmitido. Bier (2001) concorda esta definição ao afirmar que a 
multiplicidade de propósitos da comunicação sobre riscos torna o processo de identificação das necessidades da audiência fundamental antes de iniciar qualquer esforço de comunicação.

Kasperson et al (1988) dizem que os receptores utilizam o contexto sociocultural para dar sentido à mensagem e fazem inferências sobre a relação entre fonte e sinais, tornando-os interdependentes. Como resultado, fonte e sinais são percebidos como uma unidade. Frewer (2004) complementa ao afirmar que quando o receptor não confia na fonte da informação a mensagem tende a influenciar os receptores na direção oposta da desejada pela fonte.

Devido ao uso do contexto sociocultural pelo receptor na leitura da mensagem, Kasperson et al (1988) também afirmam que cada mensagem contém significados factuais, inferências, relações de valor e significados simbólicos. As informações factuais são o conteúdo explícito da mensagem já as inferenciais são as conclusões que o receptor pode obter a partir das informações factuais e do contexto sociocultural. Os símbolos culturais resultam em implicação de valor e os símbolos presentes na mensagem são fatores-chave para dispararem a atenção dos indivíduos e moldar seu processo de percepção.

Kasperson et al (1988, p. 181) definem a amplificação social do risco como "o fenômeno no qual os processos, estruturas institucionais, comportamento dos grupos sociais e respostas dos indivíduos formatam a experiência social dos riscos, contribuindo para a percepção das consequências do risco". A partir desta definição, entendem que as raízes da amplificação social do risco residem na experiência social do risco, tanto direta como indireta, e no grau de confiança das informações. Portanto a amplificação social dos riscos pode resultar em impactos nos negócios ou pressão política e social. Os autores dizem que a comunicação sobre risco pode atenuar ou acentuar a percepção de risco, resultando em consequências sociais e econômicas que podem aumentar ou reduzir o risco em si. A amplificação social da percepção dos riscos funciona como um mecanismo corretivo para a subestimação da análise técnica frente à percepção do público.

\subsubsection{Formatos da comunicação sobre riscos}

Para Kasperson et al (1988), o conceito técnico de risco requer atenção na comunicação sobre riscos, pois envolve somente a probabilidade dos eventos e a magnitude de suas 
consequências, sendo considerado falho pelos autores para informar aos demais grupos interessados as decisões tomadas. Este conceito técnico pode inicialmente possuir uma imagem de qualidade superior, porém ao desconsiderar a percepção do público interessado pode resultar em desconforto ou desconfiança no processo de tomada de decisão.

Plough e Krimsky (1987) também não consideram adequado que a comunicação sobre riscos seja baseada somente em metodologias de análise de riscos, pois nestas metodologias predominam a visão dos especialistas, podendo despertar reações de desconfiança devido a sensações de informações incompletas ou falsas. Leiss (1996) também alerta que não deve ser utilizada somente a linguagem técnica para elaborar a comunicação sobre risco, de modo a evitar o uso de linguagens que a audiência pode não entender, permanecendo o desacordo entre as partes mesmo com uma boa comunicação. Frewer (2004) concorda tanto com Plough e Krimsky (1987) como Leiss (1996) ao afirmar que somente a estimativa técnica não é suficiente para formar políticas de gestão de risco que sejam aceitas pelos consumidores.

Fischhoff (1995) alerta que danos na confiança em relação à comunicação sobre riscos podem ser irreversíveis, sendo as dúvidas ou desconfianças geradas difíceis de superar. Bier (2001) recomenda que na presença de desconfiança, o comunicador inicialmente escute a audiência com o intuito de entender os pontos importantes para esse público, lidando seriamente com estes pontos além de tentar criar mecanismos ou processos para que os interessados possam acompanhar e monitorar os eventos e as decisões tomadas; recomenda também que quando o público interessado é formado por um grande número de pessoas deve-se formar um Comitê para acompanhar as decisões, viabilizando o processo.

Kasperson et al (1988) relacionam as seguintes táticas utilizadas por comunicadores para evitar reações de desconfiança do público, porém sem sucesso: criar distrações ou utilizar o discurso de que as agências representam o público para evitar a publicação de informações e fazer uso de autoridade independente para tentar assegurar a confiança do público. Segundo os autores, a comunicação sobre riscos deve educar o público para entender como os especialistas abordaram o problema e obtiveram determinada solução. Os autores também destacam que deve ocorrer a aprendizagem mútua, ou seja, os especialistas devem entender como o público considera outros fatores como valores e cultura para incorporá-los em suas análises. 
Plough e Krimsky (1987) adicionam que a comunicação sobre risco ocorre em contextos de incerteza, e que nesses contextos, questões sobre a aceitabilidade de riscos estão intimamente ligadas aos problemas de percepção de honestidade e justiça, portanto, em alguns casos, a comunicação não deve focar nos riscos, mas na transmissão de segurança e confiança.

Schapira et al (2001) pesquisaram o formato da comunicação sobre riscos de tratamento médicos em condições que o paciente participa da tomada de decisão. Nesse estudo foi evidenciada a preocupação com a credibilidade da informação sobre os riscos das opções de tratamentos quando a informação era apresentada com denominadores baixos, como 3/10 ou $1 / 5$, sendo o principal questionamento dos pacientes relacionado ao tamanho da amostra que originaram os dados; foram evidenciadas também as diferenças de interpretações entre frequência e probabilidade do evento no contexto em que a informação é relevante para a pessoa. Outra característica da comunicação sobre riscos evidenciada é a maior facilidade de compreensão dos dados quando utilizadas figuras relacionadas ao tema para transmitir a informação, porém, identificou-se maior dificuldade quando a informação era apresentada em gráficos.

Frewer (2004) também analisa as formas que contribuem para uma comunicação sobre riscos mais compreensível e, assim como Schapira et al (2001), o autor destaca o uso de ilustrações e representações gráficas de fácil leitura como meio comunicacional eficiente. Entretanto alerta que o uso equivocado deste recurso pode confundir a audiência da comunicação.

Bier (2001) diz que não há estudos empíricos que mostrem um formato ideal para a comunicação sobre riscos. Para o autor, o melhor formato para a comunicação sobre riscos depende do propósito da comunicação; e apresenta três barreiras para o entendimento na comunicação de riscos: falta de familiaridade do público com o tema; falta de modelos mentais relevantes para o assunto e a presença de conceitos errados. $\mathrm{O}$ autor também afirma que o uso de exemplos na comunicação sobre riscos pode auxiliar na falta de familiaridade com o tema. Já na presença de conceitos errados, recomenda que seja explicado para o público os erros e não somente apresentar o conceito correto. 
É esperado que a gestão de riscos contribua para uma alocação mais eficiente dos recursos da organização, alinhando as expectativas de retornos e de exposição a risco dos gestores às desejadas pelos demais interessados na empresa. Desta forma, a gestão de risco poderá contribuir tornando os gestores e conselheiros da empresa cientes e alinhados em relação aos riscos que a empresa está exposta, contribuindo com critérios que auxiliem os gestores na tomada de decisões em direção ao aumento de valor da empresa. Como consequência, os conselheiros terão à sua disposição mais ferramentas para monitorar os gestores, evitando ações oportunistas destes últimos, além de preparar a organização para atuar na ocorrência dos eventos identificados.

Portanto, a organização estará mais bem preparada para enfrentar os riscos do ambiente, reduzindo a quantidade de capital necessário para garantir seus contratos. Esta redução poderá ser utilizada para aumentar o escopo de contratos da firma ou permitir a retirada de capital dos proprietários, reduzindo a exposição a riscos destes na empresa.

Para a implantação do processo de gestão integrada de risco é necessário definir o apetite ao risco e à tolerância ao risco da empresa, os quais devem ser definidos pelo seu Conselho de Administração e postos em prática pela gestão. Estas definições serão decorrentes das percepções sobre os riscos dos indivíduos que compõem o Conselho. Logo, para que a decisão do Conselho seja alinhada com os interesses dos acionistas ou demais grupos interessados, é necessária a comunicação entre o Conselho e estes públicos sobre os riscos que a empresa está exposta. Esta comunicação também é necessária entre as estruturas de governança e de gestão para que as decisões sobre riscos da empresa sejam respeitadas e operacionalizadas. Portanto, esta comunicação pode colaborar no alinhamento entre os membros do Conselho interessados na organização e gestão, resultando em maior transparência dos processos de gestão e controle da empresa. Contudo, para que ocorra este alinhamento, é necessário um processo de comunicação de risco eficaz que considere as percepções tanto dos especialistas como dos não especialistas destes grupos envolvidos.

No contexto dos intermediários do mercado de capitais, a gestão de risco pode colaborar também para a estabilidade e melhora da transparência deste mercado e, consequentemente, colaborar para o aperfeiçoamento das instituições do mercado de capitais. 


\section{METODOLOGIA}

Nos estudos de Liebenberg e Hoyt (2003), Kleffner et al (2003), Beasley et al (2005) e Pagach e Warr (2007) são relatadas dificuldades para evidenciar a gestão de risco corporativa e variáveis que indiquem a qualidade desta prática. Identifica-se, portanto, uma oportunidade de estudos mais aprofundados sobre o tema para tornar os conceitos e práticas envolvidos mais claros e possibilitar avanços nas teorias relacionadas a essa prática. Riege (2003) e Eisenhardt (1989b) consideram que através da observação profunda e detalhada seja possível desenvolver teorias que possam ser testadas. Portanto, neste trabalho propõe-se um caráter exploratório com objetivo de entender o fenômeno da comunicação na gestão de risco corporativo de forma profunda, de modo a possibilitar o desenvolvimento de hipóteses e proposições em estudos futuros, conforme sugere Yin (1984).

Assim sendo, o objetivo da pesquisa está em entender relações e não enumerar ou medir eventos relacionados ao sistema de comunicação na gestão de risco corporativo. Segundo Yin (1984) questões do tipo "como" possuem cunho explanatório, sendo recomendados pelo autor os métodos de estudo de casos, experimentos ou pesquisas históricas para estudos com esse tipo de questão. Portanto, devido ao tipo do problema desta pesquisa ser do tipo "como" este estudo terá uma abordagem qualitativa.

O método de pesquisa histórica possui as características de não utilizar o controle dos eventos comportamentais e focar em fatos passados. A segunda característica deste método o descarta nesta pesquisa, pois o objeto deste estudo é um fenômeno contemporâneo. A abordagem de experimento é caracterizada por foco em eventos contemporâneos e controle dos eventos estudados. Devido ao pouco conhecimento sobre o fenômeno que será pesquisado torna-se impossível realizar o controle de seus eventos, tornando inviável a aplicação de tal método.

O estudo de caso é caracterizado pelo foco em fenômenos contemporâneos sem a necessidade do controle dos eventos relacionados a este. Devido às características do método de estudo de caso serem aderentes ao fenômeno pesquisado, este é o utilizado. 
Segundo Eisenhardt (1989b), a questão de pesquisa define o tipo de organização a ser estudada e os dados que a ser coletados, entretanto a autora alerta que o método de estudo de caso não deve ser utilizado para testar hipóteses, mas sim construir teorias que surgirão durante a pesquisa. Riege (2003) complementa que o método de estudo de caso deve ser utilizado quando o fenômeno não está totalmente descoberto e compreendido, o que traz a necessidade de uma investigação profunda. Lee (1989) adiciona às características do método de estudo de caso a possibilidade de gerar novas teorias para que sejam elaboradas e testadas hipóteses. A partir das características já citadas do objeto desta pesquisa e das características destacadas pelos autores, verifica-se aderência do método ao objetivo deste estudo.

Para a validade científica de um estudo de caso, Riege (2003) considera que a pesquisa deve ser fundamentada em uma teoria, para esta tenha validade interna e externa. Segundo o autor, a validade interna estabelece o fenômeno de forma crível e identifica os padrões e similaridades dos componentes significantes, enquanto a validade externa permite a extrapolação dos achados e o entendimento destes para exploração dos construtos.

Eisenhardt (1989b) alerta ao pesquisador que utilizará estudos de caso para evitar especificações de relações a priori por conhecer ou considerar que conhece sobre o assunto pesquisado. Pois as relações especificadas a priori podem resultar em conclusões rápidas que poderão ser viesadas ou mesmo falsas.

\subsection{Critérios de seleção}

Eisenhardt (1989b) considera a seleção do caso um dos aspectos mais importantes do estudo de caso, pois ajuda a controlar variações irrelevantes além de tornar mais claro o domínio da pesquisa. Segundo a autora, a escolha do caso deve visar à replicação de um estudo ou estender a teoria, preenchendo categorias específicas ou promovendo o estudo de casos polares.

Devido à importância para o desenvolvimento econômico do país e pela sofisticação da gestão de riscos do mercado de capitais, espera-se identificar em organizações deste setor práticas de gestão de risco corporativo que possam vir a contribuir para o conhecimento científico sobre o tema. Desta forma, a escolha do caso visa à extensão da teoria com o uso de um caso polar. 
Portanto, os candidatos a caso para este estudo são organizações que atuam no mercado de capitais, em especial bolsas de valores ou empresas de balcão organizado. No escopo nacional foram identificadas três empresas intermediadoras do mercado de capitais: BM\&FBOVESPA, CETIP S.A. e BOVESBA (Bolsa da Bahia). Mas, discrepâncias de escopo, tamanho e abrangência de atividades entre as três organizações inviabilizam a comparação necessária a um estudo de caso múltiplo. Optou-se, portanto em utilizar no escopo nacional apenas uma organização, a BM\&FBOVESPA, devido ao seu conjunto de serviços, tamanho e relevância para o mercado nacional e internacional. Bolsas de valores internacionais como Nyse, CME e Bolsa de Londres foram descartadas desta população devido à dificuldade de acesso e por estas organizações realizarem somente atividades relacionadas à negociação, enquanto a BM\&FBOVESPA executa os processos de negociação e pós-negociação. Assim sendo, esta pesquisa desenvolve um estudo de caso único.

\subsection{Coleta de dados}

Eisenhardt (1989b) recomenda que antes da coleta de dados sejam selecionadas as categorias e dimensões dos dados que serão coletados para tornar viável a investigação dentro de grupos similares. Segundo a autora, estas categorias e dimensões devem ser sugeridas pela revisão da literatura, mas também podem surgir durante a coleta de dados. Campomar (1991) ratifica Eisenhardt (1989b) ao considerar imprescindível a preparação do protocolo de pesquisa em um estudo de caso. Este protocolo, segundo o autor, deve relacionar as atividades a serem realizadas e os procedimentos a serem seguidos na coleta de dados.

Conforme recomendado por Eisenhardt (1989b) e Campomar (1991), foram selecionadas dimensões a partir da revisão da literatura e dos objetivos específicos deste estudo. A partir destas dimensões, foi elaborada uma lista de itens a serem compreendidos dentro destas dimensões e a partir destes itens foi elaborada uma série de questões guias que compõem o protocolo de coleta de dados. Estas questões foram chamadas de questões guias, pois são as perguntas que o pesquisador procura responder durante a coleta de dados e não necessariamente são as perguntas que elaboradas para um público-alvo da coleta de dados. $\mathrm{O}$ conjunto de dimensões, itens a compreender e questões guias estão no apêndice I deste trabalho. 
Yin (1981) recomenda que os dados coletados sejam registrados precisamente e que estes sejam organizados em tópicos relevantes para o estudo de caso a fim de permitir a integração de evidências de diversas fontes. Campomar (1991) complementa que para o uso do método de estudo de caso é importante a determinação dos instrumentos de coleta de dados que podem ser entrevistas, documentos, literatura, observação experiência ou outros artefatos. Para este estudo utilizam-se como instrumento de coleta entrevistas e documentos catalogados e armazenados em um banco de dados conforme recomendado por Yin (1981).

Eisenhardt (1989b) entende que no estudo de caso as fases de coleta e análise de dados devem ser sobrepostas para flexibilizar a coleta de dados, permitindo ajustes para o entendimento do fato em profundidade. Porém, a autora alerta que o pesquisador deve focar no problema da pesquisa e coletar os dados sistematicamente para que não fique sobrecarregado com uma quantidade de informação que pode causar uma "paralisia por excesso de dados." A autora também afirma que o uso de triangulação na coleta de dados adiciona robustez ao estudo; e recomenda que durante a fase de coleta de dados o pesquisador se pergunte o que está aprendendo com aquele caso e como o caso atual se diferencia dos demais já estudados para que consiga identificar o ponto de saturação, situação em que a coleta de dados poderá ser encerrada. Alerta também que durante a coleta de dados emergem conceitos e relações que devem ser comparados com as evidências para identificar se tais conceitos e relações se encaixam com os dados levantados, aumentando a validade interna da pesquisa. Considera que estes conceitos e relações devam ser comparados com outras teorias, principalmente as conflitantes, para aumentar a validade externa da pesquisa e destacar oportunidades para a criação de novas teorias.

\subsection{Análise de dados}

Eisenhardt (1989b) diz que a análise dos dados é a etapa mais difícil em um estudo de caso, por não existir um padrão e ser a etapa menos documentada. Por isso, recomenda que o pesquisador torne-se íntimo de cada caso estudado, permitindo identificar padrões únicos de cada um antes de generalizar conclusões para todos os casos da pesquisa. Entretanto, reconhece que neste método o pesquisador trabalha com dados limitados e possui também capacidade limitada de processamento que podem resultar em conclusões prematuras e muitas vezes falsas. 
Segundo Campomar (1991), o estudo de caso envolve a análise intensiva de um número relativamente pequeno de situações com ênfase na completa descrição e entendimento do relacionamento dos fatores de cada situação. O autor complementa que neste método as análises e inferências são obtidas por análises de situações e analogias contendo comparações dos achados com teorias, modelos e outros estudos de caso; considera que este método permite a descoberta de relações que não seriam encontradas de outras formas.

Para Yin (1981) as conclusões de um estudo de caso devem ser construídas a partir da interpretação acurada dos fatos considerando diversas explicações para estes; e que a conclusão deve ser baseada na alternativa que pareça mais congruente com os fatos. Campomar (1991) entende que as conclusões específicas baseadas em inferências e explicações permitem generalizações que sejam usadas como base para novas teorias.

\subsection{Limitações da pesquisa}

A característica do não controle do estudo de caso observada em Yin (1984) é considerada por Lee (1989) como uma fonte potencial de problemas para uma pesquisa de estudo de caso. Dentre as fontes potenciais do problema Lee (1989) e Eisenhardt (1989b) destacam a restrição na replicação da pesquisa, as reduzidas possibilidades do método em desenvolver generalizações e o controle das observações para identificar quais fatores realmente influenciam o fenômeno como outros pontos fracos do método. Apesar destas restrições Yin (1981) alerta que uma pesquisa que utilize o método de estudo de caso não deve ser apenas uma narrativa, mas apresentar conclusões com alternativas para explicar o fenômeno estudado, congruentes com os fatos.

Eisenhardt (1989b), por sua vez, afirma que o uso intensivo de dados empíricos no estudo de caso pode aumentar a complexidade da teoria gerada e tornar difícil a distinção entre os conceitos e as relações mais importantes, que possam ser generalizadas, das relações e conceitos particulares do caso. 
Adiciona-se às limitações da pesquisa o fato do pesquisador, autor deste trabalho, ser funcionário da organização estudada. O que contribui para o acesso as informações, porém limita a pesquisa por conflitos de interesse entre as partes e pela postura conservadora adotada na publicação de informações sobre a organização e seus processos. 


\section{ANÁLISE DO CASO}

Este capítulo apresenta a análise da organização selecionada e está divido em duas partes. Na primeira parte, descreve-se o caso baseado em modelos de análise de comunicação levantados na revisão teórica; e na segunda parte, faz-se uma análise do caso utilizando-se as demais teorias apresentadas no segundo capítulo desta pesquisa.

\subsection{Descrição da empresa utilizada no caso: BM\&FBOVESPA ${ }^{9}$}

A BM\&FBOVESPA foi fundada em 2008, a partir da fusão entre a Bolsa de Valores de São Paulo (Bovespa) e a Bolsa de Mercadorias e Futuros (BM\&F). Como uma das consequências da fusão. Esta nova organização herdou a presença no mercado de capitais nos instrumentos de ações, derivativos de ações, títulos de renda fixa, títulos públicos federais, derivativos financeiros, moedas à vista e commodities agropecuárias. Devido à amplitude de instrumentos, a BM\&FBOVESPA é considerada hoje a principal instituição brasileira de intermediação para operações do mercado de capitais.

Outra característica da BM\&FBOVESPA é a execução das atividades de negociação (trading) e pós-negociação (post-trading) que a torna única entre as maiores bolsas de valores do mundo. Pois nas demais bolsas de valores com expressão internacional são exercidas apenas atividades relacionadas à negociação, sendo as atividades de pós-negociação exercidas por outras empresas. Portanto, o escopo de atividades da BM\&FBOVESPA envolve tanto a negociação como o registro, compensação e liquidação dos ativos listados, além de atuar como depositária central destes ativos.

Para realizar as atividades de pós-negociação, a BM\&FBOVESPA possui uma estrutura de registro, compensação e liquidação (clearing) das operações para garantir o correto funcionamento dos mercados em que a empresa atua, garantindo que as operações realizadas em seu ambiente sejam liquidadas nas condições e prazos estabelecidos. Além das clearings,

\footnotetext{
${ }^{9}$ Os dados da empresa estudada - história, estrutura entre outros, foram extraídos do seu site (BM\&FBOVESPA, 2011).
} 
a organização possui o Banco BM\&F para auxiliar na consolidação das operações realizadas em seu ambiente.

Nas atividades de pós-negociação, a BM\&FBOVESPA opera como contraparte central das operações. Neste papel, a organização assume uma posição entre a ponta compradora e vendedora honrando a operação frente a uma ponta caso a outra falhe em seu compromisso.

A BM\&FBOVESPA realiza as funções de divulgação das informações de suporte ao mercado e gerencia os riscos das operações realizadas em seu ambiente. Para auxiliar nestas atividades, a empresa conta com a BM\&FBOVESPA Supervisão de Mercados (BSM) que fiscaliza as operações e atividades dos participantes do mercado, agentes de custódia e dos agentes de compensação para identificar violações, condições anormais de negociação e comportamentos que possam por em risco o funcionamento, a transparência e a credibilidade dos mercados de sua atuação.

Decorrente de sua área de atuação, a BM\&FBOVESPA está sujeita à regulação e supervisão da Comissão de Valores Mobiliários (CVM) e do Banco Central do Brasil (BC). As práticas da BM\&FBOVESPA também são certificadas pela Securities Exchange Commission (SEC), Securities and Futures Authority (SFA), ISO 9001:2000, G-30 do Committee on Payment and Settlement Systems (CPSS), International Organization of Securities Commissions (IOSCO) e International Securities Services Association (ISSA).

A BM\&FBOVESPA é uma empresa de capital aberto que possui suas ações listadas em seu pregão no segmento do Novo Mercado. Conforme representado na Ilustração 5, seu Conselho de Administração é atualmente formado por 11 membros, sendo 6 membros independentes e nula a presença de membros da Diretoria Executiva. Para assessorar o Conselho de Administração, a empresa mantém os seguintes comitês: Comitê de Auditoria, Comitê de Governança e Indicação, Comitê de Remuneração e Comitê de Risco. 


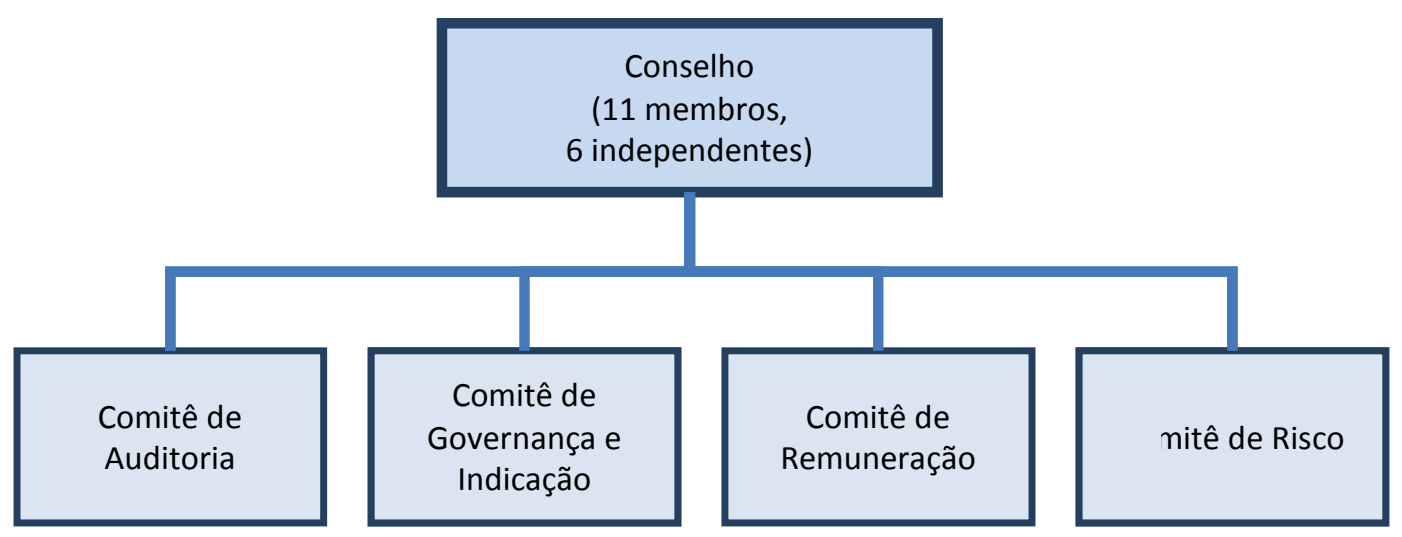

Ilustração 5 - Estrutura permanente de governança da BM\&FBOVESPA

A Diretoria Executiva é composta por 6 membros e assessorada pelos Comitês de Agronegócio, de Mercado, Técnico de Risco de Mercado, do Clube de Atletismo e Comitê de Normas, como apresentado na Ilustração 6.

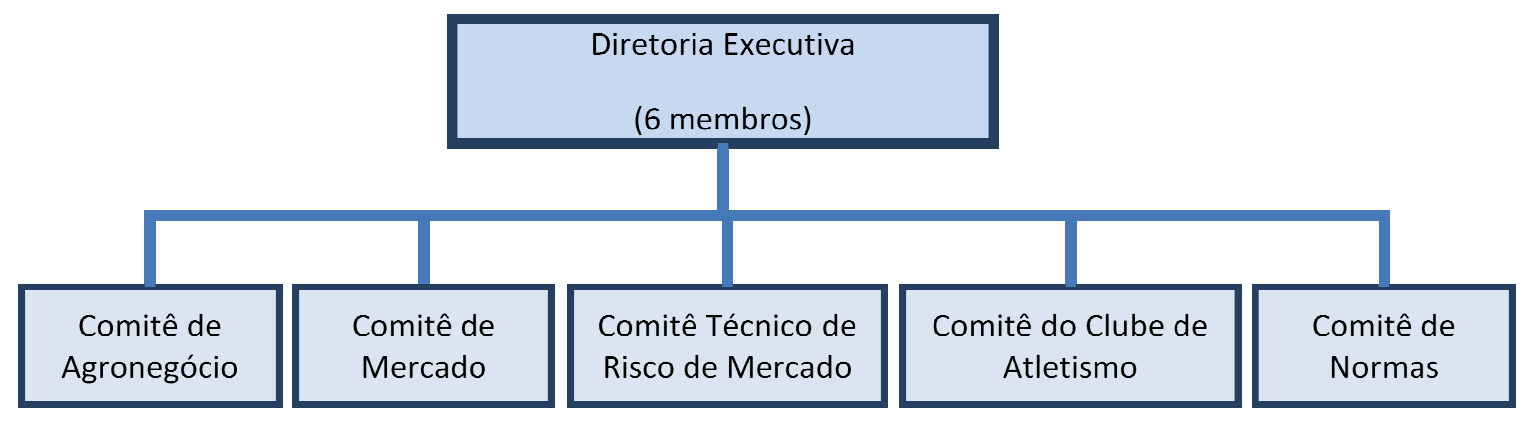

Ilustração 6 - Estrutura da Diretoria Executiva da BM\&FBOVESPA

Em relação à gestão de risco, a empresa apresenta dois principais grupos de especialistas nesta área. O primeiro grupo é formado pela Diretoria de Sistemas de Risco, que é responsável pela gestão de riscos específicos relacionados à gestão dos riscos ligados ao mercado de capitais. Esta diretoria apresenta fortes características da gestão de risco em silos, pois cada uma de suas gerências é responsável por uma categoria de risco.

O segundo grupo é formado pela Diretoria de Auditoria e Riscos Corporativos (DARC), cujas responsabilidades centram-se em supervisionar a gestão de riscos das áreas de negócio considerando a correlação entre os diversos riscos, além de disseminar boas práticas de gestão de riscos às áreas supervisionadas e fomentar a criação da cultura de gestão de riscos na organização. 


\subsubsection{Principais estruturas de governança e de gestão envolvidas no processo de gestão de risco corporativo}

Dentre as estruturas de governança e de gestão presentes na BM\&FBOVESPA, foram identificadas como as estruturas mais relevantes nos processos de Gestão Corporativa de Risco, as seguintes:

- Conselho de Administração.

- Comitê de Auditoria.

- Comitê de Riscos.

- Presidente Executivo e Diretoria Executiva.

- Diretoria de Auditoria e de Risco Corporativo.

Também foram identificadas duas visões que relacionam estas principais estruturas, como mostra a Ilustração 7. Na primeira visão, representada pelas linhas cheias, são apresentadas as principais estruturas e suas relações de subordinação. Nesta visão, a Diretoria de Auditoria e Risco Corporativo (DARC) é representada como subordinada ao Presidente Executivo e como par das demais Diretorias Executivas. Entretanto, esta Diretoria é demandada e reporta-se diretamente aos Comitês de Auditoria e de Risco Corporativo, configurando a segunda visão que representa a relação entre áreas demandantes e demandadas, no caso da DARC representada pelas linhas tracejadas. Devido à demanda direta do Comitê de Auditoria e do Comitê de Riscos Corporativo à DARC esta Diretoria executa atividades de supervisão relacionadas com as atividades dos Comitês de Auditoria e de Risco Corporativo e não atividades relacionadas a gestão da organização como as demais Diretorias Executivas. 


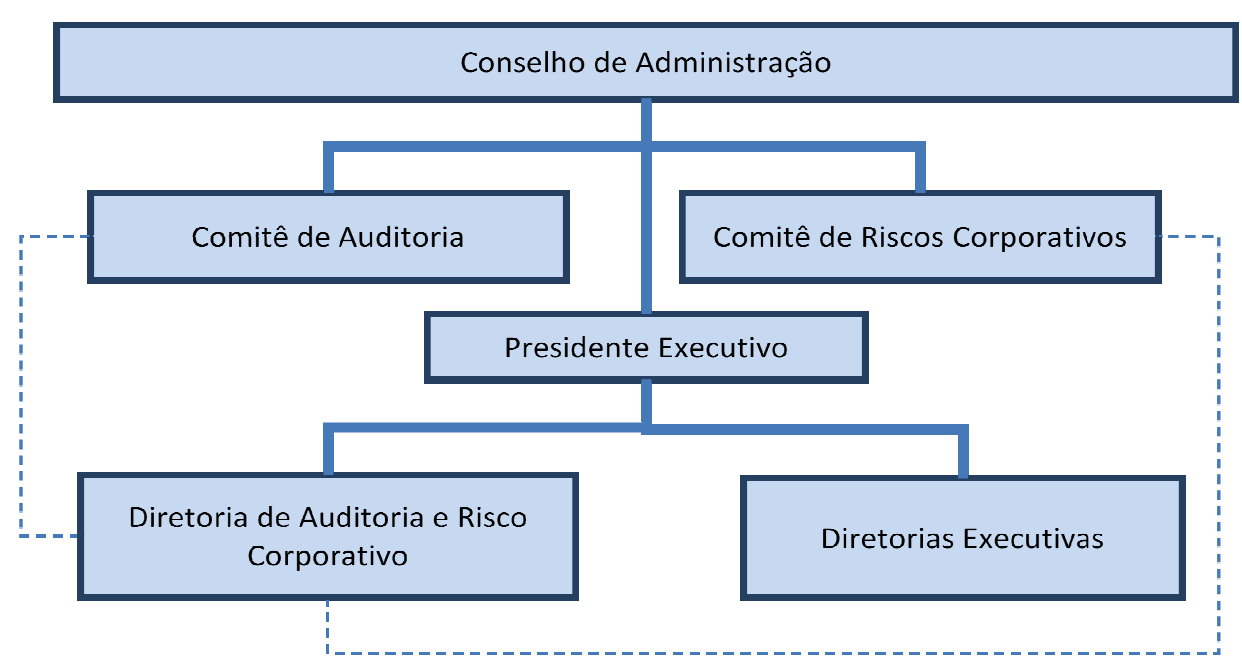

Ilustração 7 - Organograma com as principais estruturas de gestão e de governança presentes na gestão de risco corporativo

\subsubsection{Conselho de Administração}

O Conselho de Administração é a estrutura responsável por determinar o apetite e a tolerância da organização ao risco e por supervisionar a exposição da empresa aos riscos identificados e a adoção de medidas para controlar esta exposição. Tanto as informações de apetite e tolerância ao risco como a exposição da empresa aos riscos agregados são transmitidas durante as reuniões do Conselho.

O Conselho de Administração possui o Comitê de Auditoria e o Comitê de Risco Corporativo para a especialização das atividades de supervisão dos riscos da organização. Estes Comitês atuam de forma complementar na gestão de riscos, uma vez que o Comitê de Auditoria possui foco no cumprimento dos processos e, por consequência, nos principais riscos associados a estes, enquanto o Comitê de Risco Corporativo supervisiona as atividades ligadas aos riscos agregados e residuais.

Os resultados das avaliações dos riscos agregados e das principais medidas para controle da exposição a estes riscos chegam ao Conselho de Administração por meio de relatórios elaborados pela DARC com a supervisão do Comitê de Riscos, os quais são compostos por: 
" “Dashboard”, que apresenta de forma resumida, por gráficos e escalas, a situação da empresa em relação aos principais riscos agregados.

- Análise dos riscos agregados. Estas análises detalhadas de cada risco agregado são compostas pela avaliação da organização em relação ao risco, pela definição do risco analisado e pelos dados utilizados na análise. Estes dados são apresentados principalmente na forma de gráficos.

- Um anexo com uma explicação de cada método utilizado nas análises dos riscos.

Além do relatório periódico, o Conselho de Administração e/ou o Comitê de Risco podem solicitar análises ad hoc sobre riscos ou cenários específicos com o intuito de avaliar estratégias ou potenciais respostas da organização. Estas análises também são apresentadas nas reuniões do Conselho, geralmente no formato de uma apresentação oral acompanhada por material explicativo.

Tanto os relatórios periódicos como o material resultante das análises ad hoc ficam de posse dos Conselheiros ao fim das reuniões para que estes possam solicitar aos especialistas de sua confiança uma análise profunda, caso julguem necessário.

\subsubsection{Comitê de Auditoria e Comitê de Risco Corporativo}

O Comitê de Auditoria é responsável pela supervisão do cumprimento dos processos da organização envolvendo também o controle de riscos específicos dos processos. Entretanto, o foco das atividades do Comitê de Auditoria são os processos de forma individual e não do ponto de vista agregado, o que confere a estes processos características da gestão de risco em silos.

As atividades do Comitê de Gestão de Risco Corporativo complementam a gestão de riscos da organização, uma vez que o foco deste Comitê é supervisionar as atividades relacionadas à gestão dos riscos agregados, riscos residuais e riscos de modelo. Os riscos agregados são a visão agregada dos riscos individuais contemplando suas correlações, fornecendo uma visão complementar e mais abrangente em relação à visão de cada risco por si só. Os riscos residuais são riscos individuais que a área "dona do risco" não gerencia, seja por falta de 
condições, como limitações dos modelos utilizados ou restrição de tempo ou pessoas, como por deliberação do gestor.

Ambos os Comitês recebem as diretrizes do Conselho de Administração e demandam à Diretoria de Auditoria e Risco Corporativo para a execução de atividades que visam operacionalizar suas tarefas de supervisão.

\subsubsection{Diretoria de Auditoria e de Risco Corporativo}

Inicialmente, as funções de Auditoria Interna e de Gestão de Risco Corporativo foram desempenhadas por diretorias distintas, entretanto estas diretorias foram unidas originando a Diretoria Auditoria e Risco Corporativo (DARC), conhecida internamente na empresa como DAU.

As atividades desta diretoria relacionadas com os objetivos do Comitê de Auditoria são de entender e supervisionar os processos de negócio, sendo parte destas atividades a avaliação de riscos específicos destes processos.

Esta diretoria também desempenha atividades relacionadas aos objetivos do Comitê de Risco Corporativo que visam supervisionar a gestão dos riscos agregados e de modelos, além de auxiliar na identificação de riscos a que estão expostas, disseminar e induzir melhores práticas de gestão de riscos.

A DARC é responsável pela compilação dos dados das Diretorias Executivas, relacionados aos riscos que a organização está exposta, resultando nos relatórios a serem apresentados tanto para o Comitê de Risco como para o Conselho de Administração. Os dados compilados e agregados de cada Diretoria Executiva também são enviados para a respectiva diretoria e para o presidente executivo da empresa.

Além dos relatórios periódicos, tanto o Conselho de Administração como o Comitê de Auditoria, Comitê de Risco ou a Diretoria Executiva podem solicitar análises ad hoc com foco específico na avaliação da exposição da empresa a determinados riscos ou eventos. 
A principal atividade da DARC relacionada à gestão corporativa de riscos é a supervisão da gestão dos riscos agregados. Esta atividade é realizada com o auxílio de modelos próprios e através de comparações dos resultados destes com os números da organização e com os resultados dos modelos das áreas de negócio. Complementando esta atividade, a DARC realiza também a indução de melhores práticas de gestão de risco que consta em obter o engajamento, tanto de gestores como das demais pessoas das áreas de negócio, para formar uma cultura de riscos e disseminar conceitos, práticas e modelos de gestão de riscos.

A DARC também desenvolve atividades ligadas à integração dos modelos de riscos para obter um modelo unificado de riscos da organização e atividades de avaliação do risco de modelo.

\subsubsection{Presidente Executivo e Diretorias Executivas}

As diretorias executivas são os "donos dos riscos", ou seja, são os responsáveis pelo controle da exposição da organização aos riscos, sejam individuais ou agregados. Há casos específicos em que alguns destes riscos são de responsabilidade de uma diretoria ou gerência subordinada a uma diretoria executiva.

As diretorias executivas e suas áreas subordinadas controlam os riscos por meio de modelos ou indicadores próprios. Estas diretorias enviam periodicamente informações para a DARC para alimentar os modelos desta área, que são utilizados na compilação dos relatórios, tanto ordinários como ad hoc. Entretanto o presidente executivo e os diretores também podem solicitar análises específicas para a DARC sobre o comportamento dos riscos envolvidos na estratégia da organização ou em cenários específicos.

Os diretores executivos são as primeiras pessoas que recebem os resultados das análises desenvolvidas pela DARC para que iniciem as ações corretivas necessárias o mais rápido possível e reduzam ao máximo a janela de exposição da organização ao nível considerado inadequado de risco.

Na Ilustração 8 são representadas as principais estruturas envolvidas na gestão de risco da organização e os fluxos de informações que ocorrem entre estas estruturas. Os fluxos, 
representados pelas linhas, são bidirecionais, ou seja, representa tanto as informações que a estrutura envia como também as informações que a estrutura recebe.

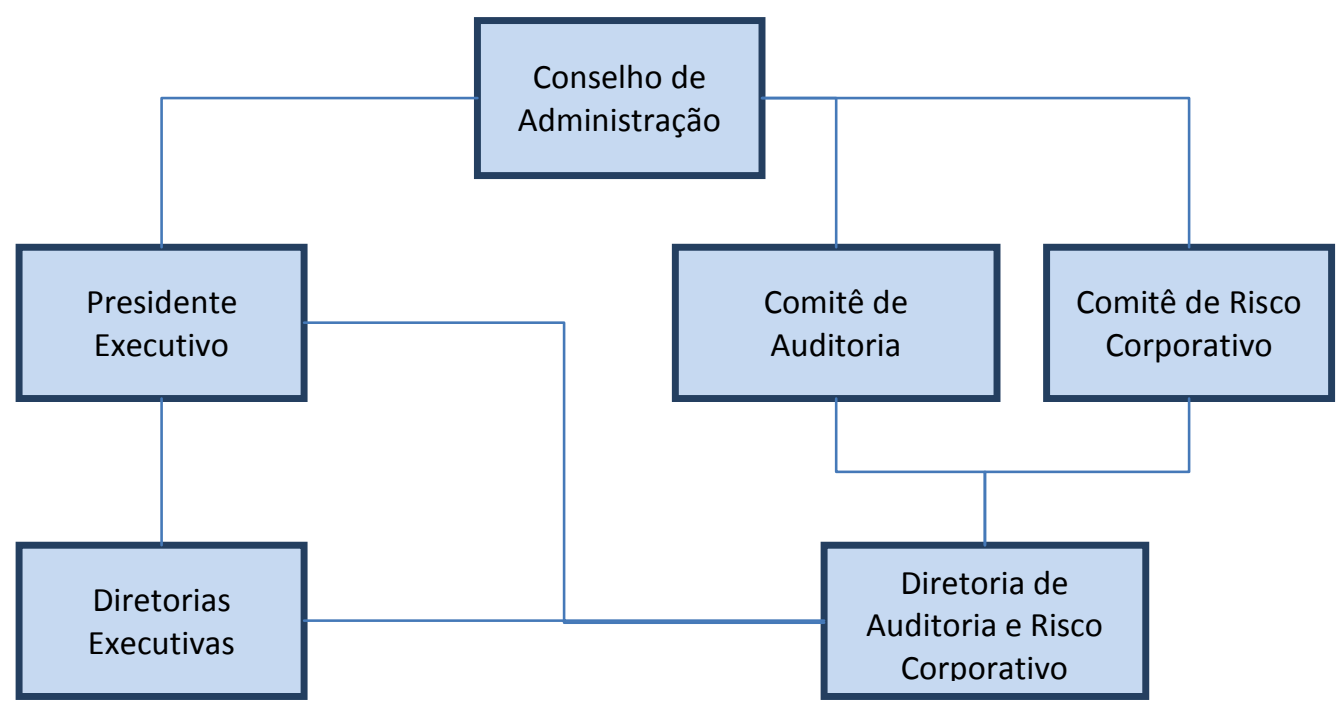

Ilustração 8 - Representação das principais estruturas envolvidas na gestão de risco e o fluxo de informação entre elas

\subsubsection{Comunicação sobre riscos entre as estruturas de gestão e de governança corporativa}

Para a análise da comunicação entre as principais estruturas envolvidas na gestão corporativa de riscos serão utilizados os modelos apresentados em Lasswell (2007), as três fases da comunicação apresentadas em Leiss (1996) e os objetivos relacionados em Bier (2001). Devido à semelhança entre o modelo apresentado em Plough e Krimsky (1987) e Lasswell (2007), conforme exposto no Quadro 1 o primeiro não será utilizado explicitamente.

Quadro 1 - Comparação entre os modelos de comunicação de Plough e Krimsky (1987) e Lasswell (2007)

\begin{tabular}{|c|c|}
\hline Plough e Krimsky (1987) & Lasswell (2007) \\
Intenção & Com qual finalidade? \\
Conteúdo & Diz o quê? \\
Audiência & Para quem? \\
Fonte & Quem? \\
Fluxo & Em qual canal? \\
\hline
\end{tabular}


Na primeira análise da comunicação no processo de gestão de risco corporativo foi utilizado o segundo modelo apresentado em Lasswell (2007) que é composto por três grupos: As pessoas que observam o ambiente e transformam estas observações em informações; as pessoas responsáveis pela transmissão destas informações ao restante de sociedade; e pessoas que transmitem a herança social entre as gerações.

Adaptando este modelo para o contexto de gestão corporativa de riscos, pode-se considerar a herança social como os valores da organização representados na gestão de risco corporativo pelo apetite e tolerância a risco da organização, além das principais medidas para o controle da exposição da organização aos riscos identificados. Portanto, este grupo é composto pelo Conselho de Administração, Comitê de Auditoria e Comitê de Risco Corporativo.

O grupo responsável pela transmissão das informações é composto pela DARC, que é responsável pela compilação dos dados das diretorias de negócio e estimativa dos riscos agregados, além da transmissão destas informações para as estruturas de gestão e de governança da organização.

O grupo representado pelas pessoas que observam o ambiente e geram as informações a partir destas observações é composto pelos profissionais das gerências e diretorias de negócio. Estas áreas foram consideradas neste grupo, pois estão em contato direto com o ambiente interno e externo da organização e suas atividades os colocam na posição de observadores e coletores das informações relacionadas aos riscos de suas atividades.

O resumo desta análise é apresentado na Ilustração 9, com as linhas cheias representando as informações que são geradas a partir de observações dos ambientes internos e externos e pelas linhas tracejadas que representam a comunicação de valores do Conselho de Administração para as demais áreas. 


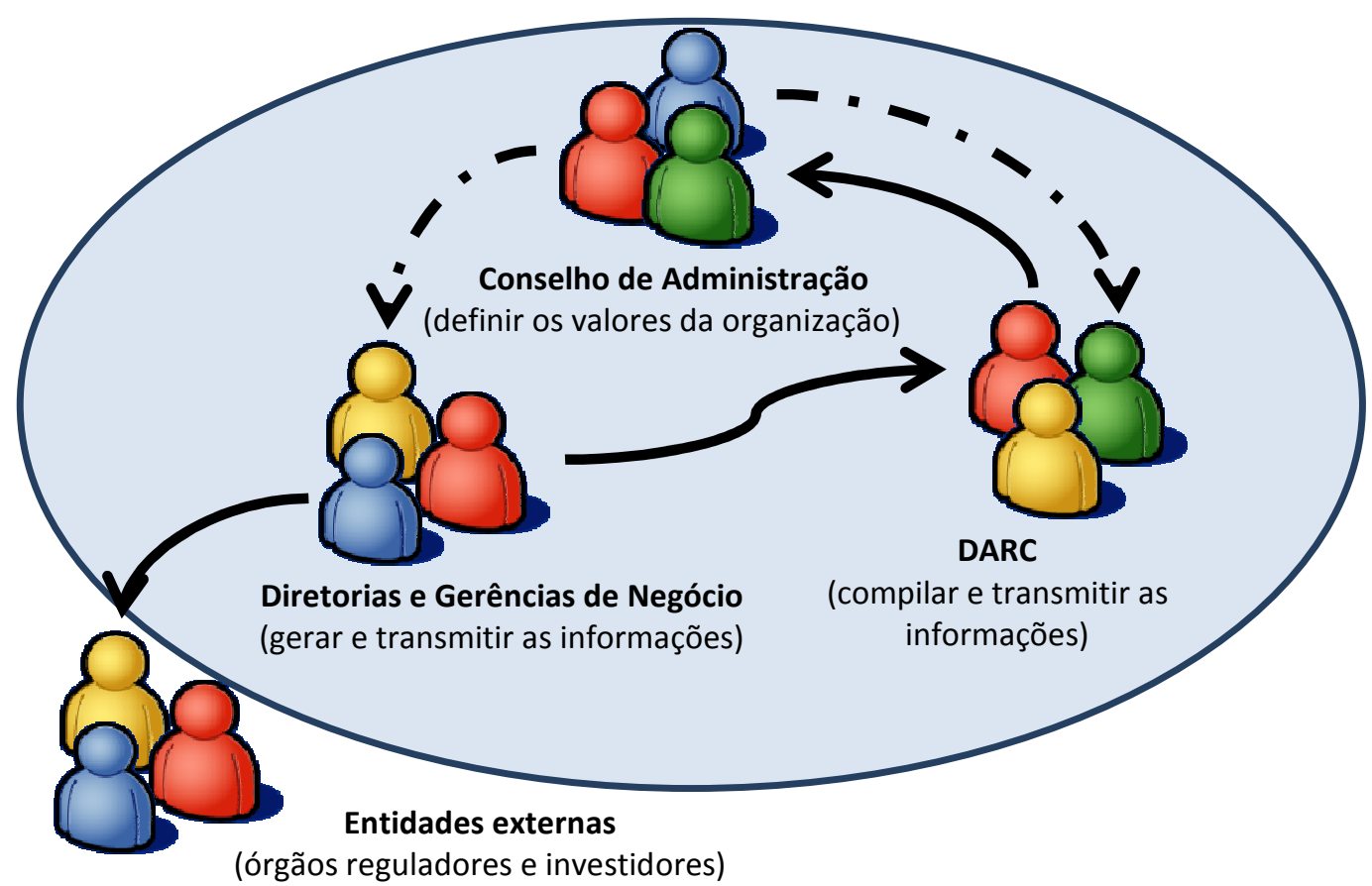

Ilustração 9 - Diagrama de comunicação entre as diversas áreas

A segunda análise da comunicação sobre riscos utiliza o primeiro modelo apresentado por Lasswell (2007), as fases de comunicação Leiss (1996) e os objetivos relacionados em Bier (2001). Estuda a comunicação entre cada par de estruturas participantes da gestão de risco corporativo. Estas análises serão apresentadas no seguinte formato:

- Estrutura conforme o modelo de Lasswell (2007): Quem? Diz o quê? Em qual canal? Para quem? Com qual finalidade?

- Finalidade da comunicação, seguindo os objetivos descritos em Bier (2001).

- Fase da comunicação, seguindo o modelo apresentado em Leiss (1996).

- Formato dos relatórios, baseado em Schapira et al (2001).

\subsubsection{Comunicações que envolvem o Conselho de Administração}

As responsabilidades do Conselho de Administração na gestão de risco corporativo são: 
- Estabelecer os níveis de apetite e tolerância a risco da organização.

- Supervisionar os indicadores e as atividades de controle de riscos agregados.

O apetite e a tolerância a risco são transmitidos pelo Conselho de Administração aos Comitês de Auditoria, de Risco e Presidente Executivo, sendo esta deliberação insumo para suas atividades. O acompanhamento dos níveis de apetite e tolerância ao risco, sua evolução e as principais atividades relacionadas são acompanhados periodicamente em relatórios elaborados pela DARC.

As comunicações descritas acima são realizadas durante a reunião do Conselho de Administração. Os níveis de apetite e tolerância a risco são transmitidos verbalmente e registrados em ata. Já as informações de acompanhamento dos riscos da organização e das principais atividades de controle destes são transmitidas tanto verbalmente como pelos relatórios.

Estes relatórios contêm análises realizadas pela DARC dos riscos agregados e observações das áreas de negócio e diretores executivos, sendo por meio destas observações que o diretor executivo e os gestores da área de negócio transmitem suas percepções sobre os riscos analisados e eventuais discordâncias com os resultados apresentados.

Os quadros 2 e 3 apresentam de forma resumida as características das comunicações descritas que envolvem o Conselho de Administração.

Quadro 2 - Comunicação dos níveis de apetite e tolerância a risco pelo Conselho de Administração

\begin{tabular}{|l|l|}
\hline Quem? & Conselho de Administração \\
Diz o quê? & Níveis desejados de apetite e tolerância a risco \\
Em qual canal? & Verbalmente, durante a reunião do Conselho de Administração \\
Para quem? & Comitês de Auditoria, de Risco Corporativo e Presidente Executivo \\
Com qual finalidade? & Atingir um acordo para a atuação sobre um risco / \\
& Motivar uma ação em relação a um risco \\
Fase da comunicação & $1^{\text {a }}$ fase: Comunicação de números e atividades \\
Formato dos relatórios & Registros textuais em ata da reunião do Conselho \\
\hline
\end{tabular}


Quadro 3 - Acompanhamento periódico dos níveis de risco

\begin{tabular}{|c|c|}
\hline Quem? & Comitês de Risco Corporativo e Diretoria de Auditoria e Risco Corporativo \\
\hline Diz o quê? & $\begin{array}{l}\text { Níveis atuais dos riscos agregados e estado das principais atividades de } \\
\text { controle destes riscos }\end{array}$ \\
\hline Em qual canal? & Relatório/exposição verbal, durante reunião do Conselho de Administração \\
\hline Para quem? & Conselho de Administração e Comitê de Risco \\
\hline Com qual finalidade? & $\begin{array}{l}\text { Aumento do conhecimento ou percepção dos riscos / Atingir um acordo } \\
\text { para a atuação sobre um risco / Motivar uma ação em relação a um risco }\end{array}$ \\
\hline $\begin{array}{l}\text { Fase da comunicação } \\
\text { Formato dos relatórios }\end{array}$ & $\begin{array}{l}1^{\text {a }} \text { fase: Comunicação de números e atividades } \\
\text { Indicadores em forma gráfica, gráficos/textos descritivos e explicativos }\end{array}$ \\
\hline
\end{tabular}

Além dos relatórios de acompanhamento periódico dos riscos agregados o Conselho de Administração pode solicitar análises $a d$ hoc específicas sobre algum risco ou determinados cenários. Desta forma, o Conselho consegue expor sua preocupação ou percepção com determinados riscos ou cenários para a organização, motivando sua análise e possíveis atividades de controle para estes riscos.

Os resultados destas análises também são apresentados nas reuniões do Conselho através de apresentação verbal com o acompanhamento de relatório extraordinário em papel. Assim como ocorre com as análises periódicas, os membros do Conselho ficam de posse do relatório extraordinário para consultas com especialistas de confiança. Estas comunicações são resumidas nos quadros 4 e 5 .

Quadro 4 - Solicitação de análise ad hoc pelo Conselho de Administração

\begin{tabular}{|c|c|}
\hline Quem? & Conselho de Administração \\
\hline Diz o quê? & Solicita análises $a d$ hoc de risco ou cenários \\
\hline Em qual canal? & Verbalmente e registrado em ata \\
\hline Para quem? & Comitê de Risco Corporativo \\
\hline Com qual finalidade? & $\begin{array}{l}\text { Atingir um acordo para a atuação sobre um risco / Aumento do } \\
\text { conhecimento ou percepção dos riscos / Motivar uma ação em relação a um } \\
\text { risco }\end{array}$ \\
\hline Fase da comunicação & $1^{a}$ fase: Comunicação de números e atividades \\
\hline Formato dos relatórios & Formato textual registrado em ata da reunião do Conselho de Administração \\
\hline
\end{tabular}


Quadro 5 - Apresentação de resultados das análises ad hoc

\begin{tabular}{|c|c|}
\hline Quem? & Comitê de Risco Corporativo e Diretoria de Auditoria e Risco Corporativo \\
\hline Diz o quê? & Resultado da análise ad hoc solicitada pelo Conselho de Administração \\
\hline Em qual canal? & Exposição verbal e relatórios \\
\hline Para quem? & Conselho de Administração \\
\hline Com qual finalidade? & $\begin{array}{l}\text { Aumento do conhecimento ou percepção dos riscos / } \\
\text { Atingir um acordo para a atuação sobre um risco / Motivar uma ação em } \\
\text { relação a um risco }\end{array}$ \\
\hline Formato dos relatórios & $\begin{array}{l}\text { Indicadores descritos em forma gráfica, gráficos e textos descritivos e } \\
\text { explicativos }\end{array}$ \\
\hline
\end{tabular}

\subsubsection{Comitê de Risco Corporativo e DARC}

O Comitê de Risco recebe do Conselho de Administração os níveis de apetite a risco e tolerância ao risco, conforme exposto no Quadro 2, e realiza a supervisão dos indicadores e atividades de controle relacionadas aos parâmetros fornecidos pelo Conselho de Administração.

O Comitê de Risco operacionaliza a supervisão dos riscos através da DARC e recebe desta diretoria relatórios com a análise dos riscos supervisionados, conforme resumido pelo quadro 3. Estes relatórios são avaliados e consolidados pelo Comitê de Riscos para serem apresentados nas reuniões do Conselho de Administração.

\subsubsection{Comunicações que envolvem áreas de negócio}

As áreas de negócio são as responsáveis pela execução das atividades da BM\&FBOVESPA e pelo controle de seus riscos específicos. Além da gestão dos riscos específicos estas áreas participam da gestão de risco corporativo fornecendo informações através de sistemas para a DARC gerir os riscos residuais e agregados. Outras atividades que envolvem as áreas de negócio e a DARC são atividades relacionadas à supervisão de risco de modelos, e disseminação de melhores práticas de gestão de riscos. 
As áreas de negócio são envolvidas gradualmente nos processos executados pela DARC. O primeiro contato geralmente é realizado por um gerente da DARC via contato telefônico. Seguido deste contato são realizadas reuniões em que o gerente da DARC explica os processos de gestão de riscos corporativos para os representantes da área de negócio e qual será o papel desta área de negócio nestes processos. O quadro 6 resume as características desta fase inicial da comunicação entre a DARC e a área de negócio.

Quadro 6 - Resumo da comunicação de engajamento entre a DARC e áreas de negócio

\begin{tabular}{|l|l|}
\hline Quem? & Gerente da DARC \\
Diz o quê? & Objetivos da gestão de risco corporativa \\
Em qual canal? & Verbal, através de conversas e reuniões \\
Para quem? & Gestor de uma área de negócio \\
Com qual finalidade? & $\begin{array}{l}\text { Desenvolvimento de confiança no comunicador / Atingir um acordo para a } \\
\text { atuação sobre riscos / Motivar uma ação em relação a riscos }\end{array}$ \\
Fase da comunicação & $3^{\text {a } \text { fase: Busca de parceria }}$ \\
Formato dos relatórios & Não há \\
\hline
\end{tabular}

O envolvimento da área de negócio nos processos de gestão de riscos corporativos inicia-se com membros da DARC entrevistando funcionários da área de negócio e observando suas atividades. Nesta etapa, ocorre a transmissão de informações e conhecimentos da área de negócio para a DARC para que os analistas desta tenham condições de integrar as atividades da área de negócio aos seus modelos, monitorar os riscos residuais e supervisionar os processos e modelos de gestão de risco da área de negócio. Além das entrevistas e observação, a DARC solicita à área de negócio documentações sobre seus processos, especialmente os relacionados à gestão de risco e os modelos utilizados nesta gestão. As características destas comunicações são apresentadas de forma resumida no quadro 7.

A DARC não possui poder para alterar os processos ou modelos utilizados nas áreas de negócio, pois seu papel é restrito à supervisão destas, porém pode influenciar na gestão de riscos destas áreas através de disseminação de melhores práticas de gestão de risco. 
Quadro 7 - Comunicação entre a área de negócio e a DARC

\begin{tabular}{|c|c|}
\hline $\begin{array}{l}\text { Quem? } \\
\text { Diz o quê? }\end{array}$ & $\begin{array}{l}\text { Representante da área de negócio } \\
\text { Funcionamento dos processos e modelos de gestão de riscos da área de } \\
\text { negócio }\end{array}$ \\
\hline Em qual canal? & Verbalmente, em atividades da área e através de reuniões. \\
\hline Para quem? & Membros da DARC \\
\hline Com qual finalidade? & Aumento do conhecimento ou percepção dos riscos \\
\hline & Atingir um acordo para a atuação sobre riscos \\
\hline Fase da comunicação & $3^{\mathrm{a}}$ fase: Busca de parceria \\
\hline Formato dos relatórios & $\begin{array}{l}\text { Modelos de gestão de risco, documentos com procedimentos e dados } \\
\text { utilizados nas atividades da área de negócio. }\end{array}$ \\
\hline
\end{tabular}

Obtido o conhecimento do funcionamento da área de negócio, a DARC integra este conhecimento aos seus modelos e passa a supervisionar os riscos e modelos da área analisada. A partir deste momento também é iniciada a disseminação de melhores práticas de gestão de risco com o objetivo de aumentar a qualidade dos processos e dos modelos utilizados na gestão de risco da área de negócio.

Os riscos da área de negócio e os riscos agregados são acompanhados e analisados através de coleta de dados dos sistemas utilizados pela área de negócio após aprovação do "dono da informação". Os resultados deste acompanhamento são descritos nos relatórios que são entregues ao Comitê de Riscos e apresentados para o Conselho de Administração. Porém, antes da divulgação destes relatórios para tais estruturas de governança, as análises são apresentadas para os gestores diretos da área de negócio, em reunião, para avaliação e tomada de ação, quando necessário.

Durante a reunião, os membros da área de negócio podem apresentar seus pontos de vista, divergências e percepções que são discutidas com a DARC para atingir consenso sobre o resultado da análise. Caso não seja possível atingir o consenso, há uma área específica no relatório para registro das divergências. Deste modo, tanto a Diretoria Executiva como os membros do Comitê de Risco e Conselho de Administração ficam cientes da convergência ou divergência de pontos de vista e percepções entre a DARC e a área de negócio supervisionada. Estes fluxos de comunicação são apresentados de forma resumida pelos quadros 8 e 9 . 
Após a análise pelos representantes da área de negócio, o relatório é apresentado para o respectivo diretor executivo que também pode expressar seu ponto de vista e divergências, durante a apresentação tanto verbalmente como por escrito no relatório. Por fim, estes relatórios são apresentados ao Comitê de Risco e posteriormente para o Conselho de Administração.

Quadro 8 - Comunicação periódica entre a área de negócio e a DARC

\begin{tabular}{|c|c|}
\hline Quem? & Área de negócio \\
\hline Diz o quê? & Dados sobre as atividades da área \\
\hline Em qual canal? & Sistemas da empresa, relatórios e documentos \\
\hline Para quem? & DARC \\
\hline Com qual finalidade? & Disponibilizar informações sobre os riscos da área \\
\hline Fase da comunicação & $3^{a}$ fase: Busca de parceria \\
\hline Formato dos relatórios & Texto, planilhas, gráficos e tabelas \\
\hline
\end{tabular}

Quadro 9 - Comunicação sobre os riscos agregados entre a DARC e área de negócio

\begin{tabular}{|c|c|}
\hline Quem? & DARC \\
\hline Diz o quê? & Informações sobre riscos agregados \\
\hline Em qual canal? & Eletrônico, físico e em reuniões \\
\hline Para quem? & Área de negócio \\
\hline $\begin{array}{l}\text { Com qual finalidade? } \\
\text { Fase da comunicação }\end{array}$ & $\begin{array}{l}\text { Aumento do conhecimento ou percepção dos riscos / Atingir um acordo } \\
\text { para a atuação sobre riscos / Motivar uma ação em relação a riscos } \\
3^{\mathrm{a}} \text { fase: Busca de parceria }\end{array}$ \\
\hline Formato dos relatórios & $\begin{array}{l}\text { Indicadores descritos em forma gráfica, gráficos e textos descritivos e } \\
\text { explicativos }\end{array}$ \\
\hline
\end{tabular}

Em paralelo às atividades de supervisão dos riscos da organização, a DARC realiza junto às áreas de negócio atividades relacionadas à disseminação de melhores práticas de gestão de risco e formação da cultura de gestão de risco na organização. Nestas atividades, a DARC apresenta boas práticas de gestão de risco, novos modelos de gestão de risco e as evoluções nesta área de conhecimento para as áreas de negócio. As características desta comunicação estão resumidas no quadro 10 . 
Quadro 10 - Comunicação entre a DARC e área de negócio para disseminação de melhores práticas de gestão de riscos

Quem?

Diz o quê?

Em qual canal?

Para quem?

Com qual finalidade?

Fase da comunicação

Formato dos relatórios Membro da DARC

Melhores práticas de gestão de risco

Verbal, através de reuniões e documentos disponibilizados em papel ou meio eletrônico

Membros de uma área de negócio

Aumento do conhecimento ou percepção dos riscos/

Motivar uma ação em relação a riscos

$3^{\mathrm{a}}$ fase: Busca de parceria

Não há

\subsubsection{DARC e Diretoria Executiva}

Os diretores executivos são os "donos do risco", ou seja, são os responsáveis por controlar os níveis dos riscos que a organização está exposta, principalmente os riscos agregados, baseando-se nos padrões estabelecidos pelo Conselho de Administração. Vale notar que os níveis de risco devem seguir os padrões estabelecidos pelo conselho de administração e não estarem abaixo deles, pois neste caso, a organização estaria alocando recursos de forma não considerada ideal pelos membros do Conselho.

Os níveis de apetite a risco e tolerância ao risco são comunicados ao presidente executivo durante a reunião do Conselho de Administração, conforme sintetizado no Quadro 2. O presidente executivo é responsável por comunicar estes níveis aos diretores executivos, para que estes tomem as medidas necessárias para manter ou adequar os níveis de risco aos estabelecidos pelo Conselho. Esta comunicação é resumida pelo quadro 11.

Quadro 11 - Comunicação dos níveis de risco pelo presidente executivo

\begin{tabular}{|l|l|}
\hline Quem? & Presidente executivo \\
Diz o quê? & Níveis de apetite e tolerância a risco \\
Em qual canal? & Verbalmente \\
Para quem? & Diretoria Executiva \\
Com qual finalidade? & Atingir um acordo para a atuação sobre um risco / \\
& Motivar uma ação em relação a um risco \\
Fase da comunicação & $1^{\text {a }}$ fase: Comunicação de números e atividades \\
Formato dos relatórios & Não há \\
\hline
\end{tabular}


Os diretores executivos recebem os relatórios elaborados pela DARC, tanto ordinários como ad hoc, após a avaliação de representantes das áreas avaliadas que são subordinadas a ele. Portanto, cada diretor executivo recebe as avaliações de suas áreas com eventuais comentários e posicionamentos de representantes destas.

Estes relatórios são apresentados ao diretor executivo em reunião com discussão dos resultados. Caso ocorra alguma divergência não solucionada em reunião, esta poderá ser registrada no relatório, assim como ocorrem com as áreas avaliadas. A comunicação dos resultados das análises para os diretores executivos e para o presidente executivo está resumida no quadro 12.

Quadro 12 - Apresentação de resultados de analises para a Diretoria Executiva

\begin{tabular}{|c|c|}
\hline Quem? & DARC \\
\hline Diz o quê? & Informações sobre riscos agregados \\
\hline Em qual canal? & Eletrônico, físico e em reuniões \\
\hline Para quem? & Diretor Executivo ou Presidente Executivo \\
\hline Com qual finalidade? & $\begin{array}{l}\text { Aumento do conhecimento ou percepção dos riscos / Atingir um acordo } \\
\text { para a atuação sobre riscos / Motivar uma ação em relação a riscos }\end{array}$ \\
\hline Fase da comunicação & 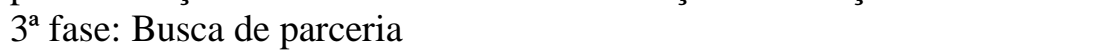 \\
\hline Formato dos relatórios & $\begin{array}{l}\text { Indicadores descritos em forma gráfica, gráficos e textos descritivos e } \\
\text { explicativos. }\end{array}$ \\
\hline
\end{tabular}

Após apresentados os relatórios para os diretores executivos e presidente executivo, estes são entregues ao Comitê de Risco e posteriormente para ao Conselho de Administração.

\subsubsection{Comunicação com investidores}

A área de Relacionamento com Investidores (RI) é um canal de comunicação entre BM\&FBOVESPA, analistas e investidores. O objetivo desta área é apresentar aos analistas e investidores o ponto de vista da organização em relação às preocupações ou dúvidas deste público de maneira a alinhar informações e percepções entre as partes.

Os principais canais de comunicação da área são a web site de Relacionamento com Investidores, telefone e e-mail. Através da web site são disponibilizadas informações por iniciativa da organização, enquanto por telefone ou e-mail as informações são disponibilizadas por demanda do investidor/analista. 
Não foi identificado algum tratamento diferenciado para informações sobre os riscos ou atividades de gestão de riscos. Em situações consideradas normais, os profissionais desta área possuem as informações necessárias para responderem aos questionamentos, porém caso não as possuam, recorrem às áreas de negócio para levantamento das informações adicionais necessárias. Também não foi identificado relacionamento ou contato direto com os processos de gestão de risco corporativa, embora seja reconhecido que esta área pode expor a organização ao risco de imagem.

Entende-se que não há uma comunicação direta sobre as informações dos riscos que a organização está exposta e as atividades de gestão de riscos entre as áreas que realizam a gestão de riscos e a área de RI e por consequência os analistas e investidores. Entretanto é possível que esta comunicação ocorra de forma indireta, através das áreas de negócio, uma vez que estas áreas participam das atividades de gestão de risco e possuem comunicação com a área de RI.

O Quadro 13 resume as características da comunicação da empresa com seus investidores.

Quadro 13 - Comunicação da organização com investidores e analistas

\begin{tabular}{|l|l}
\hline Quem? & Relacionamento com Investidores \\
Diz o quê? & Apresenta a percepção/opinião da organização \\
Em qual canal? & Web Site, telefone ou e-mail \\
Para quem? & Investidores e analistas \\
Com qual finalidade? & Desenvolvimento de confiança do público no comunicador / \\
Fase da comunicação & Aumento do conhecimento ou percepção dos riscos \\
Formato dos relatórios & Textual, gráficos e tabelas \\
\hline
\end{tabular}

\subsubsection{Comunicação com órgãos reguladores}

A comunicação sobre os riscos que a BM\&FBOVESPA está exposta ou sobre os processos de gestão destes riscos entre a empresa e órgãos reguladores ocorre quando um órgão regulador solicita estas informações à empresa. Portanto, não existe uma distribuição de informações sobre riscos e processos de gestão destes originada pela BM\&FBOVESPA para estes públicos, pois a organização não possui conhecimento de quais informações cada órgão regulador necessita sem a demanda específica. 
A Diretoria de Auditoria e Riscos Corporativos (DARC) não recebe solicitação dos órgãos reguladores, mas esta área sente-se preparada para responder a questionamentos destes órgãos caso seja necessário.

Entretanto, as áreas de gestão de riscos específicos da Diretoria de Sistemas de Risco recebem solicitações periódicas dos órgãos reguladores sobre os riscos e atividades da área. O objetivo desta comunicação é apresentar o nível de riscos e processos adotados em determinadas atividades da organização.

O Quadro 14 apresenta o resumo da comunicação entre a BM\&FBOVESPA e os principais órgãos reguladores do mercado de capitais:

Quadro 14 - Comunicação entre a empresa e órgãos reguladores

\begin{tabular}{|l|l|}
\hline Quem? & BM\&FBOVESPA \\
Diz o quê? & Presta informações solicitadas sobre riscos e processos de gestão de risco \\
Em qual canal? & Meio físico e meio eletrônico \\
Para quem? & Órgãos reguladores \\
Com qual finalidade? & $\begin{array}{l}\text { Desenvolvimento de confiança do público no comunicador / Aumento do } \\
\text { conhecimento ou percepção dos riscos / Atingir um acordo para a atuação } \\
\text { sobre um risco } \\
\text { Fase da comunicação } \\
\text { Formato dos relatórios }\end{array}$ \\
\hline
\end{tabular}

\subsection{Análise}

Após a descrição dos processos de comunicação na gestão de risco corporativo realizada na sessão neste capítulo, para a devida análise, utiliza-se o referencial teórico apresentado no capítulo 2 sobre as características da gestão corporativa de riscos da organização estudada no caso com aprofundamento nos processos de comunicação.

Ao atuar como contraparte central do mercado de capitais brasileiro, a BM\&FBOVESPA torna-se um caso extremo da visão de Barzel e Suen (1997) da empresa como um nexo de contratos garantidos pelo capital próprio da organização. Pois sua operação envolve honrar seus contratos como uma empresa tradicional e a liquidação de contratos padronizados que são os negócios originados em sua plataforma de negociação. 
Devido a esta responsabilidade relacionada ao cumprimento destes contratos, a empresa pode incorrer em sacrifício de capital próprio para sua sobrevivência e para manter a estabilidade do mercado de capitais, caso alguma das partes envolvidas não cumpra seu papel.

Como resultado, a operação da organização necessita de grande quantidade de capital para manter o equilibro do mercado em possíveis situações de estresse e um controle eficaz dos riscos a que a empresa está exposta.

O capital é formado por investimentos de diversos acionistas, resultando na assimetria de informação, moral hazard e conflitos de interesses descritos em Barzel e Suen (1997), Jensen e Meckling (1976), Fama e Jensen (1983a e 1983b), Fama (1980), Alchian e Demsetz (1972), Hill e Jones (1992), Eisenhardt (1989a) e Tirole (2006). Como descrito por estes autores, nesse ambiente há necessidade de medidas para mitigar os problemas, adotando-se estruturas e processos de governança corporativa para tal finalidade.

As atividades de controle dos riscos a que a organização está exposta são executadas tanto através da abordagem em silos como pela abordagem holística da gestão de riscos corporativos de forma complementar.

O papel do Conselho de Administração na organização é próximo do descrito em Fama e Jensen (1983b), que é ratificar as decisões de grande impacto para a organização e monitorar a alta direção da empresa.

O Conselho de Administração é formado por maioria de conselheiros independentes, considerado por Fama (1980) a melhor configuração para esta estrutura. Seu papel na gestão de riscos corporativos é definir os níveis de apetite e de tolerância a risco considerados adequados para a organização e supervisionar a situação e a gestão dos principais riscos, em consonância com Atkinson (2008).

Conforme descrito em Tirole (2006), Kose e Senbet (1998) e Menon e Williams (1994) o Conselho de Administração subdivide-se em comitês especializados, permitindo uma melhor supervisão de assuntos específicos, e que os membros do Conselho que não compõem estes comitês possam dedicar mais tempo para a supervisão de outros assuntos da organização. 
O Comitê de Auditoria possui responsabilidades descritas em Turley e Zaman (2004), Menon e Williams (1994), Bradbury (1990), Pucheta-Martínez e Fuentes (2007) e Van Gansbeke et $a l$ (2008). Além destas responsabilidades o Comitê de Auditoria também é responsável pela supervisão das atividades de controle dos principais riscos individuais relacionados aos processos que supervisiona. Desta forma, esta estrutura também realiza tarefas de supervisão da gestão de risco, porém com características da gestão de risco em silos.

A supervisão da gestão dos riscos agregados e residuais fica a cargo do Comitê de Riscos. Esta separação de supervisão das atividades na gestão de risco remete ao questionamento de Yatim (2010), Atkinson (2008) e Bates e Leclerc (2009) sobre as competências necessárias aos membros do Comitê de Auditoria e do Comitê de Riscos. A separação das atividades entre os dois comitês sugere que são diferentes as competências de cada um destes Comitês.

Aldred (2003) apresenta duas formas como as empresa lidam com a gestão de risco corporativo: pela adoção do Comitê de Risco ou pela adoção de uma Diretoria de Riscos. Na BM\&FBOVESPA, estas duas estruturas estão presentes e ambas desempenham atividades complementares na supervisão dos riscos corporativos. A Diretora de Riscos Corporativos (DARC) no caso estudado é responsável por operacionalizar as demandas do Comitê de Riscos, provendo insumos para que este Comitê supervisione os níveis de riscos que a empresa está exposta e as principais atividades de controle destes riscos.

Durante a condução das entrevistas, pode-se notar que a empresa possui uma visão de Governança Corporativa próxima da Enlightened Stakeholder Theory, apresentada por Jensen (2001). Pois alguns entrevistados citaram decisões do Comitê de Risco ou do Conselho de Administração que foram baseadas na maximização do valor da organização, mas considerando também alguns stakeholders essenciais para a operação da organização, como os potenciais efeitos das decisões para a sociedade através de reflexos na economia do país.

Como destacado em Barton et al (2001) e PRMIA (2009), a Gestão de Riscos Corporativos não visa à eliminação ou mitigação da exposição da organização aos riscos, mas ao controle desta exposição nos níveis considerados adequados pelo Conselho de Administração. 
De maneira semelhante à evidenciada em March e Shapira (1987), Coso (2004), Burnaby e Hass (2009) e PRMIA (2009), os gestores relacionam a palavra risco a eventos negativos para a empresa. Esta associação pode ter relação com a maturidade da cultura de gestão de riscos da organização que ainda está em formação.

Ao contrário do apresentado em Coimbra (2011) em seu estudo sobre a gestão de riscos corporativos em brancos brasileiros, a gestão de riscos corporativos na BM\&FBOVESPA apresenta ênfase tanto nos riscos operacionais como nos riscos financeiros, pois os resultados das análises desenvolvidas pela DARC apresentam estes dois tipos de riscos em suas análises. Entretanto, os riscos estratégicos não possuem a mesma ênfase na gestão de risco corporativo, situação que pode ser atribuída à recente adoção destes processos na organização e a formação em andamento da cultura de gestão.

Simkins e Ramirez (2008) consideram a gestão de riscos corporativos como uma evolução e uma abordagem mais sofisticada da gestão de risco em silos. No caso estudado foi identificada que a gestão de risco corporativo exerce um papel complementar à gestão de risco em silos. Pois os processos de gestão de risco corporativo possuem foco nos riscos agregados, de modelo e residuais, enquanto os processos de risco em silos controlam riscos específicos. Esta separação de papéis permite que a gestão de risco em silos seja especializada em determinados riscos considerados cruciais para a organização, enquanto as correlações entre estes e os demais riscos da organização sejam geridos pela gestão de risco corporativo.

Outra relação complementar que ocorre entre a gestão de risco corporativa e a gestão de risco em silos é a contribuição da primeira nos processos da segunda através da avaliação dos modelos utilizados e os riscos que envolvem estes modelos. Desta forma, a DARC auxilia a evolução da gestão de risco em silos além de executar o papel de avaliadora externa à área dos processos da gestão de risco em silos da área de negócio.

No estudo foi identificado o conflito entre áreas especialistas e áreas não especialistas em gestão de riscos, semelhante ao descrito em Leiss (1996). Esse conflito supostamente é mitigado através de ações que buscam a parceria entre os dois tipos de áreas. Parte destas ações possui relação com a comunicação sobre riscos, conforme apresentado em Plough e Krimsky (1987) e Leiss (1996). 
Não foi identificado conflito semelhante entre a organização estudada e seus stakeholders que não seja através dos processos de Governança Corporativa devido a não existência de uma comunicação formal e específica sobre riscos diretamente entre estas partes, o que não significa que este conflito não exista. A única comunicação direta identificada entre os stakeholders e a organização ocorre através da área de relacionamento com os investidores, porém o objetivo desta comunicação é apresentar a visão da empresa para o público.

As ações de comunicação buscam a formação da relação de parceria entre as áreas desde os primeiros contatos. Um fator identificado como positivo para a formação destas parcerias é a liberdade para os representantes das áreas de negócio apresentarem suas preocupações e percepções, tanto sobre os riscos avaliados como sobre os processos e atividades relacionadas à gestão de risco corporativa e explicação para estas áreas como suas preocupações e percepções serão consideradas nas análises e resultados.

Outro fator identificado como positivo e complementar ao anterior para formação da parceria entre a DARC e áreas de negócio é a incorporação das preocupações e percepções destas áreas nos resultados das análises da DARC e a discussão destes resultados entre as áreas antes da divulgação dos resultados para o Comitê de Risco e Conselho de Administração. Desta forma, a área de negócio pode verificar se suas percepções e preocupações foram abordadas em conformidade, além de poderem expressar eventuais discordâncias em relação aos resultados apresentados.

Por conseguinte, os fatores considerados importantes para a área de negócio e a percepção de seus membros em relação aos riscos analisados são incorporados nas análises realizadas pela DARC desde o início de suas atividades, quando área de negócio é estudada, até o momento de entrega dos resultados das análises ao Conselho através do registro de eventuais discordâncias e diferentes pontos de vista ou percepções dos representantes das áreas avaliadas.

Portanto, o julgamento intuitivo dos leigos descrito em Renn (1990) é incorporado aos modelos analíticos da DARC, sendo evitada a situação descrita por Fischhoff (1984) e Slovic (1987) em que as análises de gestão de risco não consideram fatores considerados importantes pelos leigos em gestão de risco em seus modelos. 
Um terceiro fator considerado positivo para a comunicação sobre riscos entre as áreas especialistas e áreas não especialistas é a existência de pessoas com experiência tanto em gestão de risco como nas atividades da área de negócio avaliada. Pois estas pessoas com ambas as experiências funcionam como tradutores entre as áreas, auxiliando os especialistas a incorporarem fatores importantes para os leigos em seus modelos e facilitam a contextualização das análises para os leigos em gestão de risco. A relevância deste fator pode estar ligada ao uso do contexto sociocultural no momento do receptor interpretar as mensagens da comunicação conforme apresentado em Kasperson et al (1988).

Sugere-se que a relação de parceria entre as áreas envolvidas na gestão de risco corporativa na organização estudada facilitou a comunicação das informações objetivas e subjetivas sobre os riscos que a organização está exposta. Como possível resultado estas informações e percepções são transmitidas a todos os envolvidos, incluindo o Comitê de Riscos e o Conselho de Administração, aumentando a transparência dos processos de gestão de risco corporativo. 


\section{CONSIDERAÇÕES FINAIS}

Neste trabalho foram investigadas, através de um estudo de caso, algumas características da comunicação das informações e percepções sobre os riscos entre os envolvidos nos processos de gestão de risco corporativo. Porém, para atingir o objetivo foi necessário compreender quais as estruturas envolvidas nestes processos e como estes processos são organizados e executados.

Diante dos resultados apresentados no capítulo anterior destacam-se:

- A visão da gestão corporativa de riscos como uma disciplina complementar da gestão de risco em silos, visão aparentemente contrária à apresentada em Simkins e Ramirez (2008).

- O uso da comunicação sobre riscos como ferramenta para obter o engajamento e parceria das áreas de negócio, mitigando conflitos entre os especialistas em gestão de risco e os leigos nesta área, conforme sugerido em Plough e Krimsky (1987) e Leiss (1996).

- Envolvimento no início das atividades de gestão de risco corporativo das áreas supervisionadas com incorporação de suas percepções nas análises dos especialistas.

- Discussão dos resultados entre a área supervisora e as áreas supervisionadas para entendimento dos resultados e apresentação de divergências de compreensão da análise e da percepção dos riscos analisados.

- Reportar o resultado das análises inicialmente para as áreas responsáveis pelo controle dos riscos analisados para quando necessário ocorrer a tomada de ações o mais breve possível para minimizar a exposição da organização ao nível considerado inadequado do risco.

- A importância no caso estudado do envolvimento de profissionais com experiência em gestão de riscos e nas atividades da área de negócio, servindo de tradutores entre os analistas de risco com perfil quantitativo e as áreas de negócio contextualizando a analise nas atividades da área de negócio. 
- A apresentação de um único relatório para todos os envolvidos no processo, desde os responsáveis pela área de negócio até o Conselho de Administração, com o registro de eventuais divergências de opiniões e percepções sobre o resultado das análises.

Devido às limitações do estudo e da metodologia utilizada, os resultados obtidos não são conclusivos nem podem ser generalizados, portanto de modo geral os resultados obtidos podem ser insumos para estudos futuros que visem obter conclusões e generalizações dos resultados aqui estudados.

Mais especificamente, este estudo abre questões para estudos futuros que visem o aprofundamento do conhecimento sobre a disciplina de gestão de risco corporativo e de comunicação sobre riscos. Um aspecto a ser explorado é a relação entre a qualidade da gestão de risco corporativo e a presença nestes processos de pessoas com experiência em gestão de risco e nas atividades da organização. Outro aspecto a ser explorado é o papel da gestão de riscos corporativos em relação à gestão de risco em silos. Uma terceira sugestão de pesquisa futura é a contribuição dos processos de gestão de risco corporativo na qualidade da governança corporativa de empresas e no valor da empresa. 


\section{REFERÊNCIAS}

ALCHIAN, Armen Albert; DEMSETZ, Harold. Production, Information Costs, and Economic Organization. The American Economic Review. [S.1.] v. 62, n. 5, p. 777-795, 1972.

ALDRED, Carolyn. View of corporate risks broadening. Business Insurance. [S.1.] v. 37, n. 23, 2003.

ALENCAR, C. A. L. A Atuação dos Comitês de Auditoria e Conselhos Fiscais nas Empresas Brasileiras Sujeitas à Regulamentação da SEC - Securities and Exchange Commission dos Estados Unidos da América. São Paulo, 2008. Dissertação (Mestrado em Contabilidade e Finanças). Pontifícia Universidade Católica de São Paulo (PUC),

ANDERSON, Ronald C; BIZJAK, John M. An empirical examination of the role of the CEO and the compensation committee in structuring executive pay. Journal of Banking \& Finance. [S.1.] v. 27, p. 1323-1348, 2003.

ATKINSON, William. Board-Level Risk Committee - Implications and Opportunities for Risk Managers. Risk Manage. [S.1.] v. 55, n. 5, p. 43-45, 2008.

BAINBRIDGE, Stephen M. Caremark and Enterprise Risk Management. The Journal of Corporation Law. [S.1.] v. 34, n. 4, p. 967-990, 2009.

BALLOU, B.; HEITGER, D. A Building-Block Approach for Implementing COSO's Enterprise Risk Management - Integrated Framework. Management Account Quartely. [S.1.] v. 2, n. 6, p. 1-10, 2005.

BANCO CENTRAL DO BRASIL - BACEN. O Papel dos Intermediários Financeiros. Disponível em: <http://www.bcb.gov.br/?SPBINTER>. Acesso em: 17 dez., 2011.

BARTON, Thomas. L.; SHENKIR, William G.; WALKER, Paul L. Managing Risk: An Enterprise-wide Approach. Financial Executive. [S.1.], 2001.

BARZEL, Yoram; SUEN, Wing. Equity as a Guarantee: A Contribution to the Theory of the Firm. [S.l.]: University of Washington, 1997.

BATES, E. William; LECLERC, Robert J. Boards of Directors and Risk Committee. The corporate Governance Advisor. [S.1.] v. 17, n. 6, p. 15-17, 2009.

BEASLEY, Mark S; CLUNE, Richard; HERMANSON, Dana R. Enterprise risk management: An empirical analysis of factors associated with the extent of implementation. Journal of Accounting and Public Policy. [S.1.] v. 24, p. 521-531, 2005. 
BERKOWITZ, J.; O'BRIEN, J. How Accurate Are Value-at-Risk Models at Commercial Banks? The Journal of Finance. [S.1.] v. 57, n 3, p. 1093-1111, 2002.

BIER, V. M. On the state of the art: risk communication to the public. Reliability Engineering and System Safety. [S.1.] n. 71, p. 139-150, 2001.

BM\&FBOVESPA. Sobre a Bolsa, empresas do grupo e estrutura administrativa. Disponível em: <http://www.bmfbovespa.com.br/pt-br/a-bmfbovespa/sobre-a-bolsa/ administracao/. Acesso em: 17 jul., 2011.

BRADBURY, Michael E. The Incentives for Voluntary Audit Committee Formation. Journal of Accounting and Public Policy. [S.1.] v. 9, p. 19-36, 1990.

BURNABY, Priscilla; HASS, Susan. Ten steps to enterprise-wide risk management. Corporate Governance. [S.1.] v. 9, n. 5, p. 539-550, 2009.

CAMPOMAR, Marcos Cortez. Do Uso de "Estudo de Caso" em Pesquisas para Dissertações e Teses em Administração. Revista de Administração. [S.1.] v. 26, n. 3, p. 95-97, 1991.

CARSON, Elizabeth. Factors Associated with the Development of Board Sub-Committees. Corporate Governance and International Review. [S.1.] v. 10, n. 1, p. 4-18, 2002.

CASTRO, Helio O. Portocarrero. Introdução ao Mercado de Capitais. Rio de Janeiro: IBMEC, 1979.

COASE, Ronald. The Nature of the Firm. Economica. [S.1.] p. 386-405, 1937.

COIMBRA, F. C. Estrutura de Governança Corporativa e Gestão de Riscos: Um Estudo de Casos no Setor Financeiro. São Paulo, 2011. Tese (Doutorado em Administração). Departamento de Administração da Faculdade de Economia, Administração e Contabilidade da Universidade de São Paulo (USP).

CONYON, Martin J.; HE, Lerong. Compensation Committees and CEO Compensation Incentives in US Entrepreneurial Firms. Journal of Management Accounting Research. [S.1.] n. 16, p. 35-56, 2004.

COSO. Committee of Sponsoring Organizations of the Treadway Commission. Enterprise Risk Management — Integrated Framework. [S.1.] 2004.

DELOITTE. Estudo da Deloitte identifica os 29 "destruidores de valor" das maiores empresas do mundo. São Paulo, 2006.

DERMAN, E. Model Risk. Goldman Sachs. Quantitative Strategies Research Notes. [S.1.] p. $1-11,1996$. 
DONALDSON, Thomas; PRESTON, Lee E. The Stakeholder Theory of the Corporation: Concepts, Evidence, and Implications. Academy of Management Review. [S.1.] v. 20, n. 1, p. 65-91, 1995.

DOUGALL, Herbert Edward. Capital Market and Institutions. New Jersey: Prentice-Hall, 1970.

EISENHARDT, Kathlenn M. Building Theories from Case Study Research. The Academy of Management Review. [S.1.] v. 14, n. 1, p. 532-550, $1989 \mathrm{~b}$.

Agency Theory: An Assessment and Review. The Academy of Management Review. [S.1.] v. 14, n. 1, p. 57-74, 1989a.

ESCUDER, Sergio Antonio Loureiro; TINOCO, João Eduardo Prudência. O Conselho Fiscal e a Governança Corporativa: Transparência e Gestão de Conflitos. $\mathbf{8}^{\mathbf{0}}$ Congresso USP de Controladoria e Contabilidade. São Paulo, 2008.

FAMA, Eugene F. Agency Problems and the Theory of the Firm. The Journal of Political Economy. [S.1.] v. 88, n. 2, p. 288-307, 1980.

; JENSEN, Michael C. Agency Problems and Residual Claims, Journal of Law and Economics. [S.1.] v. 26, n. 2, p. 327-349, 1983a.

Separation of Ownership and Control. Journal of Law and Economics, [S.1.] v. 26, n. 2, p. 301-325, 1983 b.

FENDER, I.; KIFF, J. CDO rating methodology: Some thoughts on model risk and its implications. BIS Working Papers. [S.1.] n. 163, p. 1-23, 2004.

FERREIRA, R. C. Proposta de um Modelo para Avaliação de Risco Operacional em Empresas não Financeiras: Estudo de Caso de uma Empresa de Telecomunicações no Brasil. 2006. Dissertação (Mestrado em Administração). IBMEC.

FISCHHOFF, Baruch; WATSON, Stephen R; HOPE, Chris. Defining Risk. Policy Sciences. [S.1.] v. 17, p. 123-139, 1984.

Risk Perception and Communication Unplugged: Twenty Years of Process'. Risk Analysis. [S.1.] v. 15, n. 2, p. 137-145, 1995.

FREWER, Lynn. The public and effective risk communication. Toxycology Letters. [S.1.] v. 149, p. 391-397, 2004.

FURUTA, F. A Relação das Características das Empresas com Adoção do Comitê de Auditoria x Conselho Fiscal Adaptado. São Paulo, 2010. Tese (Doutorado Controladoria e Contabilidade). Departamento de Administração da Faculdade de Economia, Administração e Contabilidade da Universidade de São Paulo (USP). 
GATES, Stephen. Incorporating Strategic Risk into Enterprise Risk Management: A Survey of Current Corporate Practice. Journal of Applied Corporate Governance. [S.1.] v. 18, p. 81-90, 2006.

GORGA, Erica. Análise da Eficiência de Normas Societárias: Emissão de Preferenciais, Tag Along e Composição do Conselho Fiscal, Latin American and Caribbean Law and Economics Association (ALACDE) Annual Papers Berkeley Program in Law and Economics. UC Berkeley, 2007.

HILL, Charles. W. L.; JONES, Thomas M. Stakeholder - Agency Theory. Journal of Management Studies. [S.1.] v. 29, n. 2, p. 131-154, 1992.

HORLICK-JONES, Tom. Meaning and Contextualisation in Risk Assessment. Reliability Engineering and System Safe. [S.1.] v. 59, p. 79-89, 1998.

HULL, J.; SUO, W. A Methodology for Assessing Model Risk and its Application to the Implied Volatility Function Model. Journal of Financial and Quantitative Analysis. [S.1.] n. 37, p. 297-318, 2002.

INSTITUTO BRASILEIRO DE GOVERNANÇA CORPORATIVA - IBGC. Guia de Orientação para Gerenciamento de Riscos Corporativos. Cadernos de Governança Corporativa. [S.1.] 2007.

JENSEN, Michael C. Value Maximization, Stakeholder Theory, and the Corporate Objective Function. Journal of Applied Corporate Finance. [S.1.] v. 12, n. 1, p. 8-21, 2001.

; MECKLING, William H. Theory of the Firm: Managerial Behavior, Agency Costs and Ownership Structure. Journal of Financial Economics. [S.1.] v. 3, n. 4, pp. 305-360, 1976.

JORION, P. Value at Risk. São Paulo: BMF, 1998.

KASPERSON, Roger. E; et al. The Social Amplification of Risk - A Conceptual Framework. Risk Analysis. [S.1.] v. 8, n. 2, p.177-187, 1988.

KLEFFNER, Anne E; LEE, Ryan B; McGannon, Bill. The Effect of Corporate Governance on the Use of Enterprise Risk Management: Evidence from Canada. Risk Management and Insurance Review. [S.1.] v. 6, n. 1, p. 53-73, 2003.

KLEIN, Klein, A. An examination of board committee structures. Working paper. New York: New York University, 1995.

KNIGHT, Frank. Uncertainty and Profit. New York: Houghton Mifflin Co., 1957.

KOSE, John; SENBET, Lemma W. Corporate governance and board effectiveness. Journal of Banking \& Finance. [S.1.] v. 22, p. 371-403, 1998. 
KPMG. Enterprise Risk Management - An Emerging model for building shareholder value. [S.1.], 2003.

LA PORTA, Rafael et al. Investor Protection and Corporate Governance. Journal of Financial Economics. [S.1.] v.58, p. 3-27, 2001.

LASSWELL, H. D., The structure and function of communication in society. Revista de Teoria e Pesquisa em Comunicação. [S.1.] 24 ed., p. 215-228, inverno-primavera de 2007,

LEE, Allen S. A Scientific Methodology for MIS Case Studies. MIS (Management Information System) Quaterly. [S.1.] v. 13, n. 1, p. 33-50, 1989.

LEISS, William. Three Phases in the Evolution of Risk Communication Practice. Annals of the American Academy of Political and Social Science. [S.1.] v. 545, p. 85-94, 1996.

LIEBENBERG, André P; HOYT, Robert E. The Determinants of Enterprise Risk Management: Evidence from the Appointment of Chief Risk Officers. Risk Management and Insurance Review. [S.1.] v. 6, p. 37-52, 2003.

MACHADO FILHO, Cláudio Antônio Pinheiro; ZYLBERSZTAJN, Décio. Capital Reputacional e Responsabilidade Social: Considerações Teóricas. Caderno de Pesquisas em Administração. [S.1.] v. 11, p. 87-98, 2004.

MARCH, James G.; SHAPIRA, Zur. Managerial Perspectives on Risk and Risk Taking. Management Science. [S.1.] v. 33, n. 11, p. 1404-1418, 1987.

MENON, Krishnagopal; WILLIAMS, Joanne D. The Use of Audit Committees for Monitoring. Journal of Accounting and Public Policy. [S.1.] v. 13, p. 121-139, 1994.

MURRAY, Kevin. Reputation - Managing the single greatest risk facing business today. Journal of Communication Management. [S.1.] v. 8, n. 2, p. 142-149, 2003.

NORTH, Douglass Cecil. Institutions. The Journal of Economic Perspectives. [S.1.] v. 5, n. 1, p. 97-112, 1991.

. Economic Performance Through Time. American Economic Review. [S.1.] v. 84, n. 3, p. 359-368, 1994.

OLDFIELD, G. S.; SANTOMERO, A. M. The place of Risk Management in Financial Institutions. [S.1.] The Wharton Financial Institutions Center, 1997.

OVERBAY, Zac. Exploring Reputational Risk. Risk Management. [S.1.] v. 51, p. 52, 2004.

PAGACH, Donald; WARR, Richard. An Empirical Investigation of the Characteristics of Firms Adopting Enterprise Risk Management. ERM Symposium. [S.1.] 2007. 
PLOUGH, Alonzo; KRIMSKY, Sheldon. The Emergence of Risk Communication Studies: Social and Political Context. Science, Technology, \& Human Values. [S.1.] v. 12, n. 3/4, p. 4-10, 1987.

POWER, Michael et al. Reputational Risk as a Logic of Organizing in Late Modernity. Organization Studies. British Journal of Social Work. [S.1.] v. 30, 2009.

PROFESSIONAL RISK MANAGER'S INTERNATIONAL ASSOCIATION - PRMIA. Principles of good governance. [S.1.] v. 4.9, 2009.

PUCHETA-MARTÍNEZ, Maria Consuelo; FUENTES, Cristina de. The Impact of Audit Committee Characteristics on the Enhancement of the Quality of Financial Reporting: an empirical study in the Spanish context. Corporate Governance. [S.l.] v. 15, n. 6, p. 1394$1412,2007$.

RENN, Ortwin. Risk Perception and Risk Management: A Review, Ortwin Renn Center for Environment, Technology and Development. Carle University. Risk Abstracts. Worcester, v.8, n.1 p. 1-9, 1990.

Concepts of risk: a classification. In Social Theories of Risk, ed. S. Krimsky and D. Golding, Praeger, Westport CT. Social Theories of Risk. [S.1.] p. 53-79, 1992.

The role of risk perception for risk management. Reliability Engineering and System Safety. [S.1.] v. 59, p. 49-62, 1998.

RIEGE, Andreas M. Validity and Reliability tests in case study research: a literature review with "hands-on" applications for each research phase. Qualitative Market Research: An International Journal. [S.1.] v. 6, n. 2, p. 75-86, 2003.

RUIGROK, Winfried et al. The Determinants and Effects of Board Nomination Committees. Journal of Management Governance. [S.1.] v. 10, p. 119-148, 2006.

SANTOS, Cláudia Barreto. Gestão de risco de crédito em instituições financeiras. São Paulo, 2000. Dissertação (Mestrado em Administração). Departamento de Administração da Faculdade de Economia, Administração e Contabilidade da Universidade de São Paulo (USP).

SANTOS, S. C. Risco Legal nas Instituições Financeiras: O Impacto da Jurisprudência Sobre o Setor Bancário. São Paulo, 2007. Dissertação. (Mestrado em Administração). Departamento de Administração da Faculdade de Economia Administração e Contabilidade da Universidade de São Paulo (USP).

SCHANZ, Kai-Uwe. Reputation and Reputational Risk Management. The International Association for the Study of Insurance Economics. The Geneva Papers on Risk and Insurance Issues and Practive. [S.1.] n. 31, p. 377-381, 2006. 
SCHAPIRA, Marilyn M.; NATTINGER, Ann B.; MCHORNEY, Colleen A. Frequency or Probability? A Qualitative Study of Risk Communication Formats Used in Health Care. Medical Decision Making. [S.1.] n. 21, p. 459-467, 2001.

SCHIMIT, M.; CHAO, L. Managing Growth Risk: Lessons from the Current Crisis. Centre Emile Bernheim, 2010.

SIMKINS, Betty; RAMIREZ, Steven. Enterprise-Wide Risk Management and Corporate Governance, Loyola University. Chicago Law Journal. Chicago, v. 39, p. 571-594, 2008.

SIMON, Herbert A. Rationality as Process and as Product of Thought. The American Economic Review. [S.1.] v. 68, n. 2, p. 1-16, 1978.

. Rationality in Psychology and Economics. The Journal of Business. [S.1.] v. 59, n. 4, p. S209-S224, 1986.

SLOVIC, Paul. Perception of Risk. American Association for Advanced of Science. Science Magazine. [S.1.] v. 236, p. 280-285, 17 apr. 1987.

TIROLE, Jean. The Theory of Corporate Governance. Princeton University Press, 2006.

TRAPP, A. C. G. A Relação do Conselho Fiscal como Componente de Controle no Gerenciamento de Resultados Contábeis. São Paulo, 2009. Tese (Doutorado em Administração). Departamento de Contabilidade e Atuária da Faculdade de Economia, Administração e Contabilidade da Universidade de São Paulo (USP).

TURLEY, Stuart; ZAMAN, Mahbub. The Corporate Governance Effects of Audit Committees. Journal of Management and Governance. [S.1.] v. 8, p. 305-332, 2004.

TVERSKY, Amos; KAHNEMAN, Daniel. Advances in Prospect Theory: Cumulative Representation of Uncertainty. Journal of Risk and Uncertainty. [S.1.] v. 5, p. 297-323, 1992.

VAN GANSBEKE, Esmée; EVERAERT, Patricia; SAREN, Gerrit, DE BEEIDE, Ignace. Audit Committees in Listed Companies: An International Comparison of Composition and Meetings. Corporate Ownership \& Control. [S.1.] v. 5, n. 3, p. 75-85, 2008.

VERRONE, M. A. G. Basiléia II no Brasil: Uma Reflexão com Foco na Regulação Bancária para Risco de Crédito - Resolução CMN 2.682/99. São Paulo, 2007. Dissertação (Mestrado em Administração). Departamento de Administração da Faculdade de Economia Administração e Contabilidade da Universidade de São Paulo (USP).

WILLIAMSON, Oliver Eaton. The New Institutional Economics: Taking Stock, Looking Ahead. Journal of Economic Literature. [S.1.] v. 38, n. 7, p. 595-613, 2000. 
XIFRA, Jordi; ORDEIX Enric. Managing reputational risk in an economic downturn: The case of Banco Santander. Public Relations Review. [S.1.] n. 35, p. 353-360, 2009.

YATIM, Puan. Board structures and the establishment of a risk management committee by Malaysian listed firms. Journal of Management and Governance. [S.1.] v. 14, n. 1, 2010.

YIN, Robert K. The Case Study Crisis: Some Answers. Administrative Science Quarterly. Administrative Science Quarterly. [S.1.] v. 26, n. 1, p. 58-65, 1981.

Case Study Research. Beverly Hills, CA: Sage Publications, 1984.

ZONATTO, V. C. S; BEUREN, I. M. Categorias de Riscos Evidenciadas nos Relatórios da Administração de Empresas Brasileiras com ADRs. Revista Brasileira de Gestão de Negócios. [S.1.] v. 12, n. 35, p. 141-155, 2010. 


\section{APÊNDICE 1 - QUESTÕES UTILIZADAS PARA GUIAR AS ENTREVISTAS}

\begin{tabular}{|c|c|c|}
\hline Dimensões & Itens a serem compreendidos & Questões guias \\
\hline $\begin{array}{l}\text { Assimetria de } \\
\text { informação }\end{array}$ & Estrutura de Governança & $\begin{array}{l}\text { Quais são as estruturas de governança e gestão envolvidas nos } \\
\text { processos de risco corporativo? }\end{array}$ \\
\hline $\begin{array}{l}\text { Conflito de agência e } \\
\text { Incentivos e monitoração }\end{array}$ & $\begin{array}{l}\text { Estrutura de Gestão e } \\
\text { relacionamento entre as } \\
\text { estruturas de gestão e } \\
\text { governança }\end{array}$ & $\begin{array}{l}\text { Como se relacionam estas estruturas e quais são os fluxos de } \\
\text { comunicação entre elas? }\end{array}$ \\
\hline \multirow[t]{4}{*}{ Gestão de risco } & $\begin{array}{l}\text { Gestão de risco dentro de uma } \\
\text { diretoria de negócio }\end{array}$ & $\begin{array}{l}\text { Quais riscos são geridos dentro das diretorias e quais são } \\
\text { geridos pela diretoria de risco corporativo? }\end{array}$ \\
\hline & Gestão de risco corporativo & $\begin{array}{l}\text { Quais os critérios para um risco ser gerido dentro de uma } \\
\text { diretoria ou pela diretoria de risco corporativo? }\end{array}$ \\
\hline & Relação com partes externas & $\begin{array}{l}\text { Como são integradas as iniciativas das diretorias de negócio e } \\
\text { da diretoria de risco corporativo? }\end{array}$ \\
\hline & & $\begin{array}{l}\text { Que comunicação existe entre a organização e órgão } \\
\text { regulatórios ou mercado financeiro? }\end{array}$ \\
\hline Atores envolvidos & $\begin{array}{l}\text { Finalidade de cada } \\
\text { comunicação }\end{array}$ & Quem comunica? (envia a mensagem) \\
\hline Fluxo da comunicação & $\begin{array}{l}\text { Estrutura das mensagens e } \\
\text { processos em que ocorrem }\end{array}$ & O que é comunicado? \\
\hline Conteúdo e estrutura & $\begin{array}{l}\text { Preocupações, necessidades e } \\
\text { objetivos }\end{array}$ & Qual o canal utilizado nesta comunicação? \\
\hline \multirow[t]{6}{*}{ Objetivos } & Comunicação "ponto a ponto" & Qual o público-alvo desta comunicação? \\
\hline & Fluxo amplo das informações & Qual a finalidade desta comunicação? \\
\hline & & $\begin{array}{l}\text { Quais informações atraem a atenção no processo? (disparam } \\
\text { uma comunicação) }\end{array}$ \\
\hline & & $\begin{array}{l}\text { Que informações são repassadas integralmente, alteradas, } \\
\text { perdidas ou suprimidas? }\end{array}$ \\
\hline & & Qual o conteúdo da comunicação (ou das mensagens)? \\
\hline & & Qual o formato da comunicação? \\
\hline
\end{tabular}

